\title{
Understanding flood regime changes in Europe: a state-of-the-art assessment
}

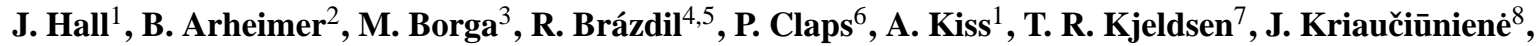 \\ Z. W. Kundzewicz ${ }^{9,10}$, M. Lang ${ }^{11}$, M. C. Llasat ${ }^{12}$, N. Macdonald $^{13,14}$, N. McIntyre ${ }^{15,}{ }^{*}$, L. Mediero ${ }^{16}$, B. Merz ${ }^{17}$, \\ R. Merz ${ }^{18}$, P. Molnar ${ }^{19}$, A. Montanari ${ }^{20}$, C. Neuhold ${ }^{21}$, J. Parajka ${ }^{1}$, R. A. P. Perdigão ${ }^{1}$, L. Plavcová ${ }^{1, * *}$, M. Rogger ${ }^{1}$, \\ J. L. Salinas ${ }^{1}$, E. Sauquet ${ }^{11}$, C. Schär ${ }^{22}$, J. Szolgay ${ }^{23}$, A. Viglione ${ }^{1}$, and G. Blöschl ${ }^{1}$ \\ ${ }^{1}$ Institute of Hydraulic Engineering and Water Resources Management, Vienna University of Technology, Vienna, Austria \\ ${ }^{2}$ Swedish Meteorological and Hydrological Institute, Norrköping, Sweden \\ ${ }^{3}$ Department of Land, Environment, Agriculture and Forestry, University of Padova, Padua, Italy \\ ${ }^{4}$ Institute of Geography, Masaryk University, Brno, Czech Republic \\ ${ }^{5}$ Global Change Research Centre, Academy of Sciences of the Czech Republic, Brno, Czech Republic \\ ${ }^{6}$ Department Environment, Land and Infrastructure Engineering (DIATI), Politecnico di Torino, Turin, Italy \\ ${ }^{7}$ Department of Architecture and Civil Engineering, University of Bath, Bath, UK \\ ${ }^{8}$ Laboratory of Hydrology, Lithuanian Energy Institute, Kaunas, Lithuania \\ ${ }^{9}$ Institute for Agricultural and Forest Environment, Polish Academy of Sciences, Poznan, Poland \\ ${ }^{10}$ Potsdam Institute for Climate Impact Research, Potsdam, Germany \\ ${ }^{11}$ Irstea, UR HHLY, Hydrology-Hydraulics Research Unit, Rue de la Doua, Villeurbanne Cedex, France \\ ${ }^{12}$ Department of Astronomy and Meteorology, University of Barcelona, Barcelona, Spain \\ ${ }^{13}$ Department of Geography and Planning, School of Environmental Sciences, University of Liverpool, Liverpool, UK \\ ${ }^{14}$ Institute of Risk and Uncertainty, University of Liverpool, Liverpool, UK \\ ${ }^{15}$ Department of Civil and Environmental Engineering, Imperial College London, London, UK \\ ${ }^{16}$ Department of Civil Engineering: Hydraulic and Energy, Technical University of Madrid, Madrid, Spain \\ ${ }^{17}$ Helmholtz Centre Potsdam, GFZ German Research Centre for Geosciences, Potsdam, Germany \\ ${ }^{18}$ Department for Catchment Hydrology, Helmholtz Centre for Environmental Research - UFZ, Halle, Germany \\ ${ }^{19}$ Institute of Environmental Engineering, ETH Zürich, Zurich, Switzerland \\ ${ }^{20}$ Department of Civil, Chemical, Environmental and Materials Engineering (DICAM), University of Bologna, Bologna, Italy \\ ${ }^{21}$ Federal Ministry of Agriculture, Forestry, Environment and Water Management, Division VII/5 - Flood Control \\ Management, Vienna, Austria \\ ${ }^{22}$ Institute for Atmospheric and Climate Science, ETH Zürich, Zurich, Switzerland \\ ${ }^{23}$ Department of Land and Water Resources Management, Slovak University of Technology, Bratislava, Slovakia \\ *now at: Centre for Water in the Minerals Industry, Sustainable Minerals Institute, The University of Queensland, \\ Brisbane, Australia \\ *** now at: Institute for Systematic Botany and Ecology, Ulm University, Ulm, Germany
}

Correspondence to: J. Hall (hall@ hydro.tuwien.ac.at)

Received: 2 December 2013 - Published in Hydrol. Earth Syst. Sci. Discuss.: 18 December 2013

Revised: 25 April 2014 - Accepted: 14 May 2014 - Published: 30 July 2014 
Abstract. There is growing concern that flooding is becoming more frequent and severe in Europe. A better understanding of flood regime changes and their drivers is therefore needed. The paper reviews the current knowledge on flood regime changes in European rivers that has traditionally been obtained through two alternative research approaches. The first approach is the data-based detection of changes in observed flood events. Current methods are reviewed together with their challenges and opportunities. For example, observation biases, the merging of different data sources and accounting for nonlinear drivers and responses. The second approach consists of modelled scenarios of future floods. Challenges and opportunities associated with flood change scenarios are discussed such as fully accounting for uncertainties in the modelling cascade and feedbacks. To make progress in flood change research, we suggest that a synthesis of these two approaches is needed. This can be achieved by focusing on long duration records and flood-rich and floodpoor periods rather than on short duration flood trends only, by formally attributing causes of observed flood changes, by validating scenarios against observed flood regime dynamics, and by developing low-dimensional models of flood changes and feedbacks. The paper finishes with a call for a joint European flood change research network.

\section{Floods are changing - are they?}

\subsection{A need for understanding flood regime changes}

Europe has experienced a series of major floods in the past years: extreme floods in central Europe in August 2002 (e.g. Ulbrich et al., 2003) and in England in summer 2007 (e.g. Marsh, 2008), unprecedented flash flooding in western Italy in autumn 2011 (e.g. Amponsah et al., 2014), and more recently extreme floods in central Europe in June 2013 (e.g. Blöschl et al., 2013a). As these and many other recent floods have exceeded past recorded levels, there is a growing concern that flooding in Europe has become more frequent and severe together with an increasing apprehension that human actions may play a key role in driving these flood changes.

There are strong physical arguments regarding a general intensification of the global hydrological cycle, with a general increase in the intensity and frequency of extreme climate events, which are likely to ultimately affect floods (IPCC, 2013). The public's growing concern on anthropogenic influences and floods seems to be mainly caused by increasing flood damage and comprehensive media coverage of extreme events (Barredo, 2009). In fact, flood damage is rising throughout the world, mainly due to an increase in the value of the assets on floodplains, even though flood protection measures have also been strengthened (e.g. Pielke et al., 2008; Di Baldassarre et al., 2010; Seneviratne et al., 2012).
However, not only has the value of assets on the floodplains changed but also the flood discharges may have changed concurrently. Hydrologists have been grappling with understanding and predicting floods since their science began. They are now exploring the question of whether floods are increasing and, if so, why. The difficulty lies in the erratic nature of floods, as one big flood event does not indicate an increasing trend in flooding. Future flood discharges and their exceedance probabilities, together with changes in the time of flood occurrence within the year, are the key variables needed in order to be able to prepare future flood management strategies. The flood discharges of a catchment, their exceedance probabilities and their seasonality are collectively termed "flood regime" in this paper.

The purpose of this paper is to review the current understanding of flood regime changes of European rivers - in particular, whether changes have been observed in the past, the drivers of change, what changes are likely to be expected in the future and what methods are currently used to detect and analyse flood changes.

Changes in coastal floods are not considered here as they are mainly linked to land subsidence and sea level rise rather than to river flooding. While dam break floods and urban floods may also be very important, this paper specifically focuses on river floods driven by rain and snowmelt (sometimes combined with ice jam), as these are the most common flood types in Europe. Changes in flood impacts such as vulnerability, exposure, perception or emergency management are also not considered as the paper specifically focuses on the changes in the river flood regime.

\subsection{Potential drivers of flood regime changes}

In order to understand flood regime changes it is important to be clear about their physical causes. Merz et al. (2012) defined three groups of potential drivers of change (river channel engineering and hydraulic structures, land use change and climatic change), which are elaborated below and summarised in Table 1.

\section{(i) Rivers}

The most obvious changes occur in the river system itself. Humankind has manipulated rivers for centuries for navigation, flood protection, food production and hydropower production among other purposes. Some rivers are more heavily modified than others, but throughout Europe, river training, hydraulic structures and sediment trapping have heavily affected most rivers through the removal of inundation areas, changes in river morphology and water depth. These modifications affect flood wave propagation and therefore can change the peak, timing and shape of the flood hydrographs. 
Table 1. Examples of potential drivers of change in flood regimes and associated variables (modified from Merz et al., 2012).

\begin{tabular}{llll}
\hline Compartment & Processes & Variables & Drivers of change \\
\hline Rivers & $\begin{array}{l}\text { Flood wave } \\
\text { propagation, } \\
\text { superposition } \\
\text { of flood waves }\end{array}$ & $\begin{array}{l}\text { River morphology, conveyance, } \\
\text { roughness, water level and } \\
\text { depth, discharge, floodplain } \\
\text { storage, river channel vegetation }\end{array}$ & $\begin{array}{l}\text { In-stream channel engineering, } \\
\text { reduction in river length, construction } \\
\text { of dikes, groynes and weirs, operation } \\
\text { of hydropower plants and reservoirs }\end{array}$ \\
\hline Catchments & $\begin{array}{l}\text { Runoff generation } \\
\text { and concentration } \\
\text { (flow path) }\end{array}$ & $\begin{array}{l}\text { Evapotranspiration, infiltration } \\
\text { capacity, runoff coefficient, } \\
\text { water storage capacity }\end{array}$ & $\begin{array}{l}\text { Urbanisation, transport infrastructure, } \\
\text { deforestation, ditch construction, wildfires, } \\
\text { agricultural management practices, } \\
\text { drainage of wetlands and agricultural areas, } \\
\text { construction of flood retention basins }\end{array}$ \\
\hline Atmosphere & $\begin{array}{l}\text { Atmospheric forcing of } \\
\text { catchment water fluxes }\end{array}$ & $\begin{array}{l}\text { Temperature, total precipitation, } \\
\text { precipitation intensity/duration, } \\
\text { snow cover and snowmelt, short and } \\
\text { long-wave radiation climate variables }\end{array}$ & $\begin{array}{l}\text { Natural climate variability at different } \\
\text { timescales, anthropogenic climate change }\end{array}$ \\
& & &
\end{tabular}

\section{(ii) Catchments}

Anthropogenic influences are also evident at the catchment scale with regard to flood generation processes. Land use has changed considerably in many areas across Europe, for example due to deforestation, urbanisation, and the construction or the abandonment of terraces in hilly landscapes. In addition, wetland drainage and agricultural practices have dramatically affected water flow paths. Such land use and management changes have been shown to affect evapotranspiration, water infiltration into the soil and surface and subsurface water storage and therefore flood-generating processes.

\section{(iii) Atmosphere}

Any change in heavy rainfall and snowmelt will induce changes in flood magnitude and timing. Changes in seasonal rainfall and evaporation will also affect the antecedent soil moisture of flood events. As local floods are embedded in a global climate context (Merz et al., 2014), flood regime changes can be brought about by natural climate variability at different timescales as well as by anthropogenic induced climatic change.

This paper examines the three above-mentioned groups of drivers with regard to their potential to cause flood regime changes. From a conceptual hydrological understanding of flood processes, a strong dependence on spatial scales of the relative impact of these drivers can be expected. The schematic in Fig. 1 shows present-day flood discharges in a hypothetical catchment with a wide floodplain attenuating the flood peak discharge magnitudes at an intermediate catchment scale.

River training or floodplain removal (Fig. 1a) will increase the flood discharges downstream of the river modification. Land use changes such as deforestation or urbanisation nor- mally occur at small scales within a catchment, so their effects will decrease with catchment size (Fig. 1b). However, throughout history there have been large-scale land use changes such as deforestation in the Middle Ages or changes in agricultural practices around 1990 in the lower Danube Basin. Overall, the combined effects can be spatially complex (Kovács et al., 2012), hence the location of land use changes within the catchment will ultimately influence the scale effect.

Changes in climate variables such as increasing or decreasing rainfall intensity occur at large spatial (synoptic) scales and may result in consistent changes of various magnitudes within a region, without obvious relation to spatial scales (Fig. 1c). In the specific case of convective precipitation increases, larger increases in the flood peak discharge would be expected at a small catchment scale.

The degree of understanding the effects of the three types of drivers on the flood regime varies. While at the catchment scale the hydrological effects of hydraulic structures are well understood, at least for individual case studies, less is known about the effect of land use/management and climate variability on the flood regime. Therefore, this paper puts particular emphasis on the effects of changing land use/management and climate.

\subsection{Methods for understanding flood regime changes}

Insights into river flood regime changes can be obtained through two main avenues. The first is a data-based approach in which no or little a priori knowledge of the system is required. In this approach, statistical methods are applied to observational flood data to detect whether significant changes have occurred. This is a useful approach if there is an extended and reliable database available, even if the physical principles are not well understood. The information obtained 

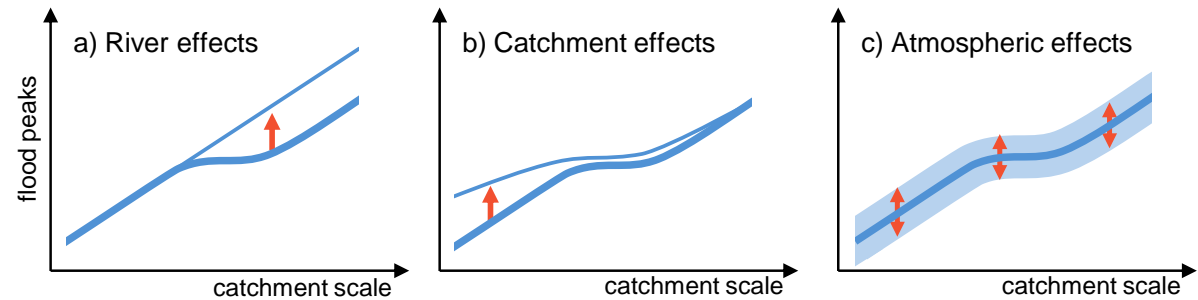

Figure 1. Hypothesised impact of three types of drivers on relative flood peaks as a function of catchment scale (based on Blöschl et al., 2007). (a) River: removing floodplain storage. (b) Catchment: land use change such as urbanisation, (c) atmosphere: climate change such as changes in rainfall characteristics. The thin line and the red arrows illustrate the effect of one of the three groups of drivers on the flood peak discharges.

is about past flood changes, which may provide the basis for anticipating future changes.

The second avenue for obtaining insights into changes of river flood regimes is a model-based approach, in which the cascade of processes from climate over catchment to the river system is represented by cause-effect relationships. These relationships can be used to simulate scenarios of future flood regimes. This is a particularly useful approach when the physical principles underlying flood generation and flood change are well understood. The information obtained is prognostic and allows inferring statements about future changes.

This paper reviews the data-based and model-based approaches in Sects. 2 and 3, respectively. Their relative strengths and weaknesses are contrasted, and results from the literature on flood changes in European rivers are presented for each of the two methods. In Sect. 4, we offer possible ways forward towards better understanding changes in the river flood regime. Based on the review in this paper, in Sect. 5 we provide recommendations for future research.

\section{Detecting changes in flood observations}

\subsection{Methods of change detection}

\subsubsection{Types of changes}

The starting point of any change detection in observed time series is to hypothesise about the type of potential changes. These may include step-changes in the mean of a series at a particular point in time (regime shift), gradual changes (trend) in the mean of the series over time or changes in the variability of the series. Based on the hypothesis about the type of change, a null hypothesis $\left(H_{0}\right)$ and an alternative hypothesis $\left(H_{1}\right)$ are formulated. For the examples above, the respective null hypotheses would be "the mean flood peak discharge of two periods are not different"; "there is no trend in the mean magnitude of flood peaks"; and "there is no change in the variability of the flood peak discharges". Changes can also occur in the extreme values of a series: for example, extreme floods may increase, without clear changes in the mean annual floods. After formulating the hypothesis, the flood data series of one or a number of stream gauges is then used to test whether the null hypothesis should be rejected or not at a chosen significance level of e.g. 5 or $10 \%$, which is the probability of incorrectly rejecting the null hypothesis.

While statistical change detection tests of flood peak discharges do not allow inferring directly the physical drivers of any change, there are known causes that affect flood peak series in certain ways (Fig. 2). The construction of hydraulic structures along rivers typically produces step changes in flood peak discharges (e.g. peaks may decrease due to the construction of large reservoir storages or may increase due to river training work) as a result of a relatively short construction period compared with the flood record length (Fig. 2a). Land use changes are often more gradual as they involve lagged responses such as slow changes in the soil properties. In addition, land use changes such as urbanisation usually proceed over many decades (Fig. 2b). Similarly, climatic variability and change are also usually expected to be more gradual, resulting in relatively slow changes in the mean and/or in the variability of flood peak discharges (Fig. 2c).

\subsubsection{Variables of changes}

Flood peak analysis is a useful primary way of analysing changing patterns in the flood regime. Typically, annual maximum flood discharges are used rather than peak over threshold flood series to avoid the constraint of choosing a constant threshold for the entire record, although time varying thresholds can also be used.

Going beyond flood discharges, a number of studies have analysed the flood seasonality in order to shed light on changes in the driving processes. Precipitation from synoptic systems, convective precipitation and snowmelt are highly seasonal; subsequently flood seasonality can provide insights into the flood producing drivers. Seasonality analysis is particularly useful when flood seasonality is compared with the seasonality of other variables that are potential drivers and with catchment state indicators such as extreme and seasonal precipitation and the runoff regime and their possible changes.

Common measures of seasonality are the mean flood occurrence date (Julian day) and the variability of mean flood 

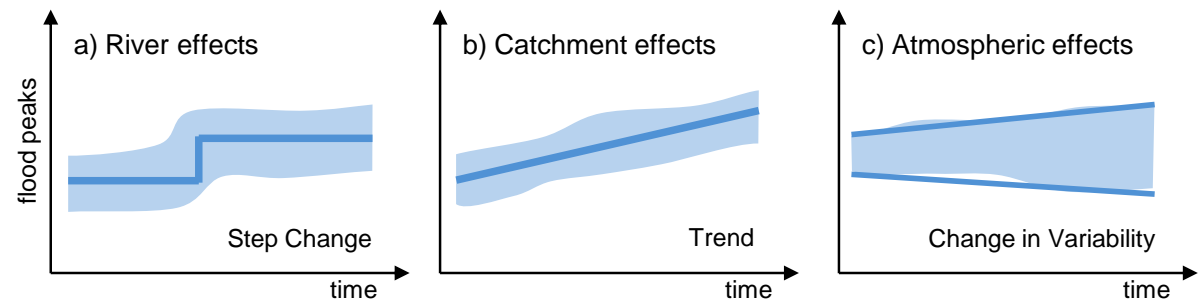

Figure 2. Typical types of changes in flood peaks over decades or centuries as caused by (a) construction/removal of hydraulic structures, (b) gradual land use change, (c) increasing variability of extreme rainfall. Shaded areas represent intra-decadal variability.

occurrences within the year. The occurrence date of a flood within the year (for a particular station) can be plotted on a unit circle to give the angle in polar coordinates (Bayliss and Jones, 1993; Black and Werritty, 1997; Burn, 1997). The direction of the average vector of all flood events can then be used to represent the mean date of occurrence for that station (Parajka et al., 2010). While many studies use flood seasonality analysis to infer flood processes (e.g. Merz et al., 1999; Beurton and Thieken, 2009; Parajka et al., 2010), only few studies have examined long-term changes (e.g. Macdonald, 2012; Arheimer and Lindström, 2014). One such study is Parajka et al. (2009), who analysed the change in seasonality of floods, extreme precipitation and the monthly rainfall and runoff regime along a transect across Austria and Slovakia over different decades.

Although flood seasonality analysis is often very useful and data tend to be readily available, the application is limited to those flood drivers that have clear seasonal characteristics. To distinguish between different flood drivers within a season, such as different rainfall types, more in depth analyses are needed, such as exploring the intra-seasonal variability of rainfall and runoff indicators (e.g. Merz and Blöschl, 2003; Macdonald et al., 2010).

\subsubsection{Methods of trend detection}

A range of statistical tests has been developed for analysing trends in the magnitude of flood peak discharge series. Such tests can focus on (i) trend analysis of individual time series, (ii) field significance of an ensemble of local stations, and (iii) analysis of coherent regional trends.

\section{(i) Change analysis of individual time series}

In the simplest case of change detection, the flood peak records of individual sites are analysed separately. Parametric tests are used for independent data that conform to a particular distribution (e.g. Student's $t$ test and Worsley likelihood ratio test), and non-parametric tests for independent data without making assumptions about the distribution (e.g. Pettit's test, Mann-Whitney $U$ test for step changes or Mann-Kendall (MK) test and Spearman's rho test for gradual changes). For a review of additional trend detection meth- ods used for hydrological extremes and their influence on the trend results, see Clarke (2013a).

As hydrological time series are usually neither normally distributed nor independent, non-parametric tests and block re-sampling methods are often preferred (Kundzewicz and Robson, 2004; Yue et al., 2012). In the case of gradual trends, the rank-based MK test is regarded as a robust nonparametric test and widely used (Petrow and Merz, 2009). However, if a positive serial correlation exists, the probability of detecting a false significant trend increases (Yue et al., 2002), in which case pre-whitening methods need to be applied to remove the serial correlation. To avoid eliminating part of the temporal trend itself (which would result in underestimating the probability of detecting a significant trend), the trend-free pre-whitening (TFPW) and modified TFPW methods have been developed (Yue et al., 2002; Önöz and Bayazit, 2012) along with other methods such as bootstrap method or variance correlation (see Khaliq et al., 2009, for a review).

\section{(ii) Field significance of an ensemble of local stations}

When examining the outcomes of local, site-specific trend analyses at a regional scale, it can become difficult to extract a consistent change signal. If a local statistical test is applied with a specific significance level, there is always the possibility of falsely rejecting the null hypothesis (no trend) (Type I error). Instead of analysing a single flood record, an analysis of an ensemble of records from different stations can increase the power of detection by reducing sampling uncertainty. The first step of such an approach is to plot the trend test results of the individual stations on a map to identify coherent spatial patterns between records from different stations (e.g. Blöschl et al., 2012). Based on these patterns, the field significance of such an ensemble of local test results over a region can be assessed by testing the null hypothesis in all time series (Douglas et al., 2000; Yue and Wang, 2002; Renard and Lang, 2007).

It is also important to take the spatial correlations of the flood peaks into account. Flood peaks are typically correlated over a distance of $\sim 100 \mathrm{~km}$ (Merz et al., 2000, 2008) and this correlation also depends on the flood-generating mechanisms (Viglione et al., 2010a). For example, flash floods tend to be 
correlated over shorter spatial distances than synoptic floods and snowmelt floods (Merz and Blöschl, 2003).

Several methods account for the spatial dependence and estimate the number of stations that may exhibit significant trends for a given significance level, if no real trends exist (Type I error). These methods include:

- an equivalent (or effective) number of stations (ENS) (Matalas and Langbein,1962)

- a bootstrap procedure (Douglas et al., 2000)

- a Gaussian copula method (Renard and Lang, 2007)

- the false discovery rate (FDR) method (Benjamini and Hochberg, 1995; Ventura et al., 2004).

When analysing the different methods, Renard et al. (2008) concluded that, if prior information on the type of regional change is available, both bootstrap and FDR method should be applied. If a weak general change is expected, they recommend the bootstrap procedure as it does not require parametric assumptions about the marginal and joint distributions of the data. On the other hand, if the changes are expected to affect only a limited number of sites the FDR procedure is recommended by them due to its statistical power.

\section{(iii) Analysis of coherent regional change}

The third group of methods focuses on the average coherent change of a region rather than on the patterns of change within the region as in (ii). As one of the key drivers, climate tends to exhibit a large-scale coherent structure so one would also expect the change in the flood response to be spatially coherent. Again, the spatial correlations of the flood peaks need to be accounted for. If the data series of all stations are uncorrelated, the total sample size will be their sum and the trend test will be powerful. However, if, for some stations, spatial correlations between the flood peaks in the same year exist, less weight is given to those stations than to stations that are not correlated with others, which reduces the effective sample size.

Several methods have been developed to test for the consistency of changes in homogeneous regions:

- Univariate tests (e.g. MK test) applied to a regional variable (index), such as the annual number of floods in a region or the mean date of occurrence of the annual maximum flood over a homogeneous region. For example, Hannaford et al. (2013) compiled a surrogate streamflow series by grouping individual time series within homogeneous regions in Europe and applied the MK test to detect coherent regional change.

- Regional statistics can also be performed with tests tailored to the regional data. In the regional MK test (Douglas et al., 2000; Yue and Wang, 2002; Sadri et al., 2009), the score is inversely proportional to the standard deviation of the regional statistics that has been used to quantify the significance level. This standard deviation depends on the mean spatial correlation coefficient between the different pairs of sites in a way that higher correlations lead to higher variance and thus to a lower score.

- A semi-parametric approach that uses a regional likelihood ratio test to compare the null hypothesis of no shared regional trend with the alternative hypothesis that all the sites of a region are affected by the same trend (Renard et al., 2008). The trend with the highest likelihood is then brought out from all possible trends and considered as representative of that region. In order to improve the robustness of the estimators against outliers and other nonlinearities the original multivariate data set can be transformed to distributions close to normal (Renard et al., 2008).

Renard et al. (2008) compared these three groups of tests and concluded that the methods have comparable testing power in detecting coherent regional trends. If the at-side trends within a region are consistent (i.e. same direction), all methods can detect the dominant change but the test results obtained from the regional variable and the regional statistic are very sensitive to the stations included. For regions with inconsistent trends, they showed that the regional variable and the regional statistics favour the dominant trend and mask minor trends, whereas the regional likelihood ratio method does not detect any trend at all. In the case that the aim of the study is to detect whether a consistent trend over a homogeneous region exists or not, Renard et al. (2008) recommend the regional likelihood ratio method. Additionally, a procedure for obtaining a regionalised, spatially averaged trend in hydrological time series with both serial and spatial correlation is presented in Clarke (2013b).

\subsection{Flood regime changes in Europe}

\subsubsection{Floods during the instrumental period}

Numerous trend detection studies have been performed on systematic flood records in Europe. In these studies, different high-flow indicators were derived from observed discharge time series, some dating back $\sim 150 \mathrm{yr}$. The results provide insights into small-scale regional patterns of increasing, decreasing, or non-detectable changes (at a specific significance level) in flood regimes (particularly flood discharge magnitudes).

Overall, it is difficult to issue a general statement on flood changes in Europe due to the diversity of processes, different observation periods, and the variety of methods applied. However, a review of the most recent studies provided below suggests some broader patterns, which are summarised below according to three climate regions relevant to flooding: (i) Atlantic western Europe and northern Europe, 
(ii) Continental central Europe and eastern Europe, and (iii) the European Mediterranean (southern non-Atlantic Europe) (see Fig. 3). If applicable, mountainous catchments located in these regions are mentioned separately due to mixed climatic and orographic influences.

\section{(i) Western Europe and northern Europe}

In central Spain, Mediero et al. (2014) found generally decreasing trends of annual maximum floods during 19592009 , with the exception of a few gauging stations in the northwestern part of Spain which showed significantly increasing trends for that period. Similarly, decreasing trends in annual maximum floods were found in the Douro Basin during 1961-2005 (Morán-Tejeda et al., 2012). In France, most regions did not show a consistent change (1968-2000), with three exceptions: increasing flood peaks in the northeast, decreasing high flows in the Pyrenees, and earlier snowmeltrelated floods in the Alps (Renard et al., 2008). For the annual maximum floods (1968-2008), the same pattern of increasing trends in annual maximum floods in the north, and decreasing trends in the south of France were found by Giuntoli et al. (2012).

In the UK, increasing trends of annual 7-day high flows (1963-2000) (Pinskwar et al., 2012) were found together with increasing trends in $Q_{5}\left(Q_{n}\right.$ corresponds to flow equalled or exceeded in $n \%$ of the daily mean flows) during 1969-2008 (Hannaford and Buys, 2012). However, an earlier period (1940-1990) did not show significant trends for 890 stations in the UK (Robson et al., 1998). Predominately, increasing trends were also detected in annual maximum flows in Ireland during 1976-2009 (Murphy et al., 2013).

Long time series from Scandinavia show a variable pattern in time and space and do not indicate an overall pattern of flood regime changes (Lindström and Alexandersson, 2004; Wilson et al., 2010). Stahl et al. (2012) found that despite increasing trends in annual mean flows, the annual 7-day high flows in Denmark and southeastern Norway decreased (1962-2004). The magnitude of spring high flows in Finland did not show significant changes for the period 1912-2004, although the mean discharges increased (Korhonen and Kuusisto, 2010).

\section{(ii) Central Europe and eastern Europe}

In central Europe, overall, Pinskwar et al. (2012) and Kundzewicz et al. (2013) found a tendency towards increasing large floods for the period 1985-2009 which reflects the recent major floods in that area. In southern, western and central Germany, annual maximum floods in $28 \%$ of the catchments showed increasing trends, particularly apparent in the winter floods, while this was not the case in the rest of Germany (1951-2002) (Petrow and Merz, 2009). For the Elbe River and Oder River, the occurrence rate of heavy winter

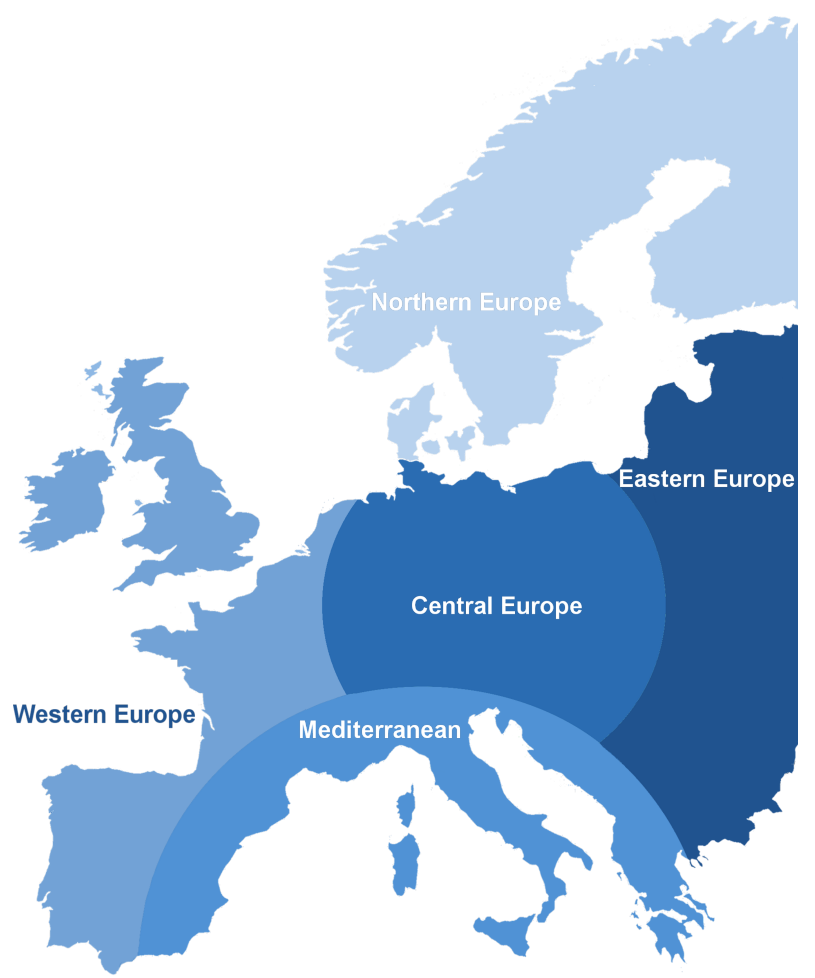

Figure 3. European sub-regions used in this review: Atlantic western Europe and northern Europe, Continental central Europe and eastern Europe, and the European Mediterranean.

floods during 1852-2002 decreased, whereas there was no trend in summer floods (Mudelsee et al., 2003).

In Poland, the mean and the variance of the annual maximum floods decreased during 1921-1990 (Strupczewski et al., 2001) and spring floods decreased for the majority of Poland's major rivers (Kaczmarek, 2003). However, after a long period without major floods, several flood events were reported in Poland from 1997 to 2010, which results in an increase of the number of regional floods (large areas of the country being flooded) for the period 19462010 (Kundzewicz et al., 2012). In Bohemia (Czech Republic), floods were particularly frequent and high in the second part of the 19th century, and generally decreased over the 20th century for the Vltava and the Elbe River (18512010, see also Fig. 5) (Brázdil et al., 2005, 2012; Yiou et al., 2006). Decreasing trends of annual maximum floods were also found in some Slovak catchments, such as the alpine Belá River (1925-2008) (Pekárová et al., 2009) and the Rybárik experimental catchment (1964-2004) (Bača and Bačová Mitková, 2007). However, the frequency of flash floods in small catchments $\left(5-150 \mathrm{~km}^{2}\right)$ was found to have increased in the last two decades (Solín, 2008).

In Hungary, record-breaking flood magnitudes have become more frequent for the Tisza basin and some tributaries during the period 1900-1999, but no significant changes were observed for most other rivers (Bárdossy et al., 2002, 
2003; Somlyódy et al., 2010). For the Danube, half of the extreme floods since the beginning of the 20th century were observed during the last two decades (Nováky and Bálint, 2013; Bacová-Mitková and Halmová, 2014). In Austria, annual maximum floods in $17 \%$ of the gauged catchments showed increasing trends during 1976-2007 (with the majority of the stations showing no significant change) with a general tendency for increasing trends in the north, decreasing trends in the south, increasing trends in winter floods in the west and decreasing trends in the southeast (Blöschl et al., 2011). In Switzerland, winter floods $\left(Q_{10}\right)$ increased in more than $50 \%$ of the catchments (1961-2000) in particular in the mountain basins (Birsan et al., 2005) and southern Alpine basins showed increase in their $95 \%$ peak quantiles (Allamano et al., 2009). An analysis of multiple time periods of annual maximum floods since 1850 suggested that the highest number of significantly increasing flood trends ( $42 \%$ of stations) was found for the period starting before 1966 and ending after 2000. However, there were also combinations of periods without significantly increasing trends (SchmockerFackel and Naef, 2010a).

For the Alpine region of France, Switzerland, Germany, Italy, Austria, and Slovenia, Bard et al. (2012) found an increasing trend in spring floods associated with snowmelt during 1961-2005. The snowmelt season started earlier and the volume and peaks of snowmelt floods from glaciers increased.

In eastern Europe, annual maximum floods in the Baltic States (Estonia, Latvia and Lithuania) generally decreased between 1922 and 2008 (Reihan et al., 2012) with an earlier occurrence of spring floods associated with earlier snowmelt (Reihan et al., 2007; Kriaučiūnienè et al., 2012). Decreases in high flows were also found in Romania for the periods 1961-2009 and 1975-2009 (Birsan et al., 2014), and other eastern European countries (1962-2004) (Stahl et al., 2012).

\section{(iii) Mediterranean}

In Spanish Mediterranean catchments, generally decreasing trends in annual maximum floods during 1959-2009 were found (Mediero et al., 2014). In Catalonia, flash floods increased during the period 1982-2007 (Llasat et al., 2010), but decreased when the study was updated until 2010. In the central parts of the Spanish Pyrenees and in the French Pyrenees decreasing trends in floods were found during the periods 1955-1995 and 1968-2000 respectively (López-Moreno et al., 2006; Renard et al., 2008), which is consistent with the decreasing trends (1952-2004 and 1962-2004) obtained by Stahl et al. (2010). For the Po River (Italy) there was no clear trend in annual maximum floods during 1920-2009 but a tendency of floods to occur in clusters (Montanari, 2012). In Greece, around Athens, an increase in flood frequency was observed in recent decades, when analysing the period 1880 2010, which was associated with increases in extreme daily precipitation (Diakakis, 2014).

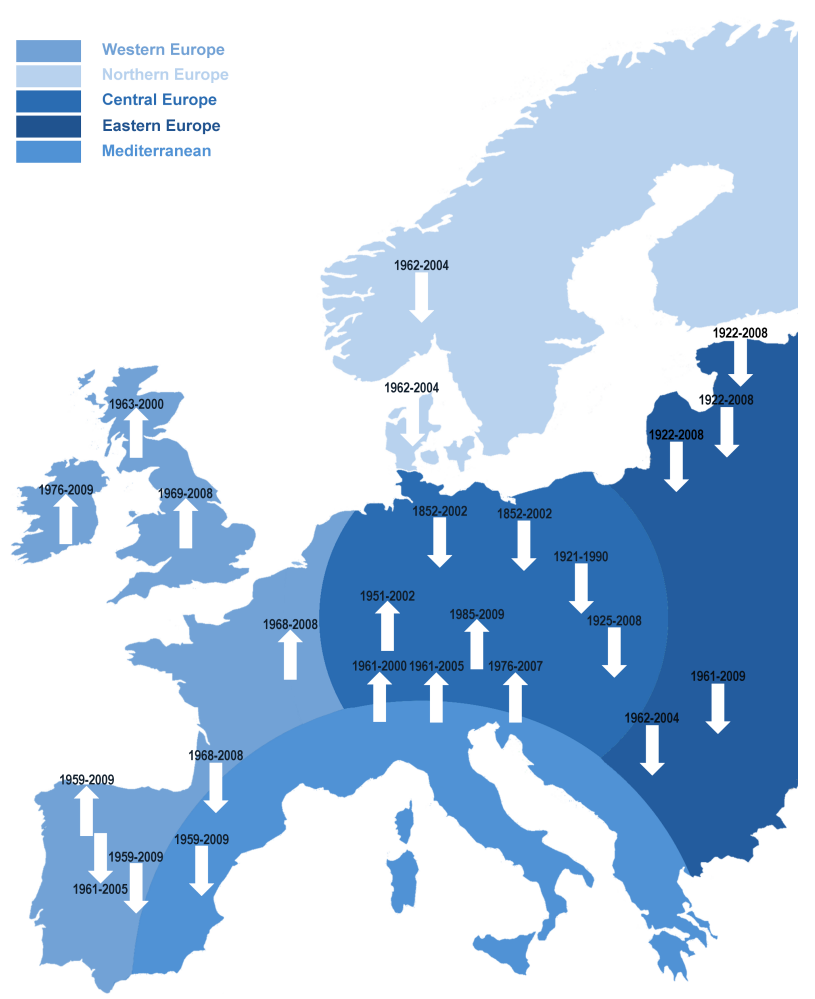

Figure 4. Schematic summarising the observed flood changes in Europe derived from cited studies using different not directly comparable change analysis methods and time periods. Note: arrows in the schematic indicate the majority of trends including regions with weak and/or mixed change patterns. Areas with no/inconclusive studies due to insufficient data (e.g. Italy) and inconclusive change signal (e.g. Sweden) are not shown.

The outcomes of the literature review presented in the above sections have been adapted into a schematic indicating some broad pattern of flood regime changes across Europe (Fig. 4). The arrows in the schematic indicate the dominant pattern of change, encompassing both significant and non-significant changes of various magnitudes and periods. Regions that do not have any change in the schematic either have no studies or data available (e.g. Italy) or the change signal is not clear (e.g. Sweden).

However, it needs to be cautioned that the general pattern displayed in the schematic has been obtained from the diverse studies reviewed above, which investigated different flood characteristics, different statistical tests and time periods. The illustration shows a mix of regional averages and individual catchments depending on literature coverage. For that reason, the schematic in Fig. 4 is sensitive to sampling uncertainty and should not be regarded as a stand-alone outcome; instead the schematic should be interpreted in combination with the original literature reviewed. 


\subsubsection{Historical floods}

The study of historical floods provides very valuable information for the period prior to systematic flow observations, which typically started on large European rivers in the 19th century. Documentary data often suffer from spatial and temporal discontinuity, yet they allow to infer the frequency, seasonality, magnitude, causes and impacts of events of a magnitude rarely witnessed within instrumental series (Barriendos et al., 2003).

Documentary sources include individual records (annals, chronicles, memory books and memoirs; weather diaries; letters; special prints; newspapers and journals; sources of a religious nature; chronograms; early scientific papers, compilations and communications; stall-keepers' and market songs and pictorial documentation) and institutional materials (account books, taxation records, reports) (Brázdil et al., 2006, 2012). Such documentary data can include information concerning the time and date of flood occurrence, meteorological and hydrological causes, details of human loss, material damage and societal responses. Flood marks (epigraphic sources) provide quantitative information about the highest water level recorded during a flood, which can be used for estimating flood peak discharges (e.g. Macdonald, 2007; Pekárová et al., 2013).

Previous research has predominantly concentrated on detailed analyses of individual disastrous flooding events (e.g. Brázdil et al., 2010) or on compiling long time series of historical flooding over the past millennium (e.g. Macdonald and Black, 2010). A European all-encompassing summary of historic floods and flood-rich/poor decades is hampered by the diversity of flood generation processes, their spatial variability, and data limitations. Below a brief overview of recent work is given according to the three climatic regions in Europe presented in Fig. 3.

\section{(i) Western Europe and northern Europe}

Previous studies have identified some broadly coherent flood-rich phases in western Europe: In France, for the Drac River and the Isère River at Grenoble three flood-rich periods 1630-1675, 1730-1780 and 1840-1860 have been identified (Barriendos et al., 2003; Cœr, 2008), for the Loire at Orléans for 1840-1870, and the mid-late 18th century and early 19th century at the River Seine at Paris were floodrich periods (Brázdil et al., 2012). Increased flooding in the mid-late 18th century is also documented in the UK at the River Ouse in Northeast England (Macdonald and Black, 2010) and the River Trent in central England (Macdonald, 2013). Macdonald (2012) found a higher frequency of summer floods during 1700-1849 than in the period 1850-1999 for the Yorkshire Ouse, a pattern also recorded in central Europe. Individual historical flood disaster analyses include the great floods of 1743, 1789 and 1860, the flood and landslide disaster of 1345 in Norway (Roald, 2002, 2003; Benestad
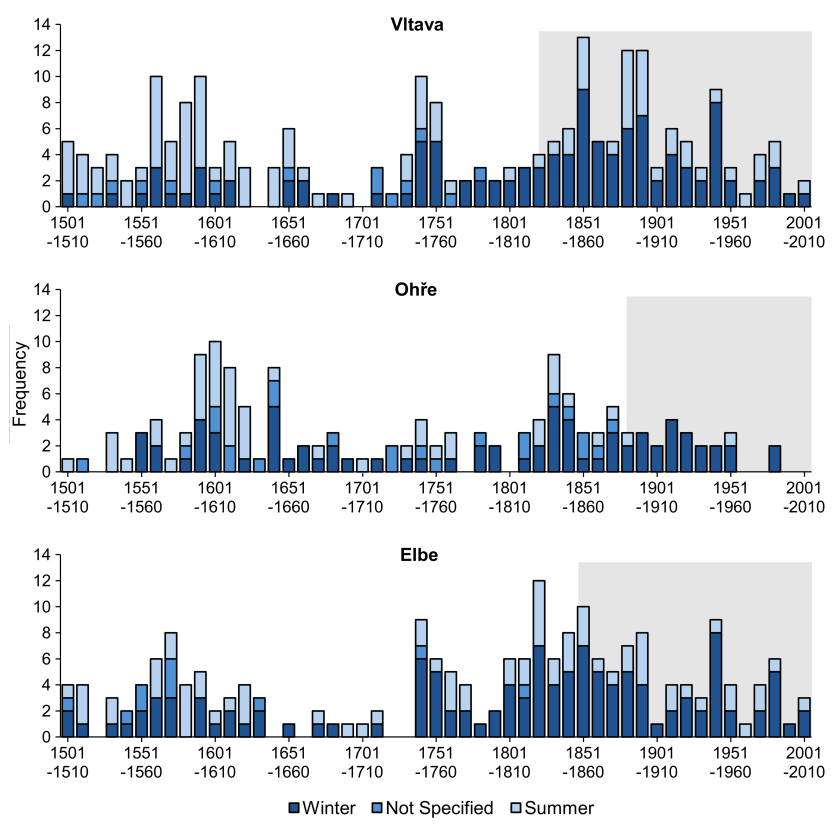

Figure 5. Decadal frequencies of floods for Bohemia (the Czech Republic) from 1501-2010 stratified by season (winter, NovemberApril; summer, May-October): the River Vltava (from České Budějovice to its confluence with the Elbe), the River Ohře (from Kadaň to its confluence with the Elbe), the River Elbe (from Brandýs to Děčín). Grey shaded areas mark the instrumental period, for which discharges larger than the 2-year flood are counted, for the pre-instrumental period floods mentioned in the documentary sources are counted (modified from Brázdil et al., 2012).

and Haugen, 2007; Rokoengen et al., 2001) and the great 1899 flood in Finland (Kuusisto, 2001). Flood data of this kind have been used for flood risk analyses by Midttømme and Tingvold (2002) and Hisdal et al. (2006).

\section{(ii) Central Europe and eastern Europe}

A systematic overview of the historical hydrology literature in central Europe is included in Brázdil et al. (2012). Therefore, here only some of the most recent results on historical flood-rich/poor periods are presented. At the River Rhine at Basel, the highest number of summer floods since 1268 occurred in the period 1651-1750, with no severe winter floods since the late 19th century (Wetter et al., 2011). A lack of extreme flood events was documented for 1877-1998 (Wetter et al., 2011), which is comparable to a similar period of few severe floods on the River Ouse at York in western Europe (Macdonald and Black, 2010). Phases of maximum flood activity in Bohemian rivers (the Vltava, Ohøe, Elbe) (Fig. 5) since 1501 are concentrated in the 19th century (particularly the second half and predominately from winter floods) and the latter part of the 16th century (summer floods) (Brázdil et al., 2005). 
Glaser et al. (2010) identified four periods of high flood frequency for 12 central European rivers from 1501: 1540-1610, 1640-1700, 1730-1790 and 1790-1840, while Schmocker-Fackel and Naef (2010b) identified 1560-1590, 1740-1790, 1820-1940 for 14 Swiss catchments. Since 1970, the Swiss flood-rich periods have often been in phase with those in the Czech Republic, Italy and Spain.

Medieval flood peaks in the Carpathian Basin are recorded in the 1330s-1350s (with the two most significant floods recorded in 1342 and 1343 (Kiss, 2009), the late 1390s1430 s and in the last decades of the 15th century (Kiss, 2011). Increased flood activity in the eastern Alpine region and the Carpathian Basin are documented in the 15th and 16th centuries, with notable flood phases in the 1400-1430s, 1470-1500s and mid-to-late 16th century (Rohr, 2007; Kiss, 2012; Kiss and Laszlovszky, 2013a, b). Apart from the early 15th century, important flood peaks were identified concerning the Danube in the Carpathian Basin at the end of the 15th-early 16th centuries, and in the second half of the 16th century (Kiss and Laszlovszky, 2013a, b).

For the European parts of the Russian Plain and the Ukraine, historical floods are usually discussed together with other climatic phenomena (e.g. Borisenkov and Pasetsky, 1983, 1988, 2003; Borisenkov, 1995; Boychenko, 2003, 2010; Klimenko and Solomina, 2010) with a few papers focusing on floods alone (e.g. Bogdanov and Malova, 2012).

\section{(iii) Mediterranean}

At the Ardeche River in France the two largest floods known since 1664 occurred in 1890 and 1827 (Naulet et al., 2005) which were claimed to have been the largest floods at the millennial scale based on palaeo-flood analysis (Sheffer et al., 2003). At the River Gardon (France) frequent events occurred during 1740-1750, 1765-1786, 1820-1846, 18601880 and 1890-1900 (Sheffer et al., 2008).

At the Llobregat River in north-eastern Spain more frequent flooding was recorded during 1580-1700, 1740-1800 and 1840-1870 (Barriendos et al., 2003; Barnolas and Llasat, 2007a). Llasat et al. (2005) found similarities in flood oscillations between northern Italy and north-eastern Spain for the periods $1580-1620,1760-1800$ and $1830-1870$. The River Tagus (Iberian Peninsula) shows high frequencies of large floods in the years 1150-1290, 1590-1610, 1730-1760, 1780-1810, 1870-1900, 1930-1950 and 1960-1980 (Benito et al., 2003) while flooding at the Tiber (Italy) was particularly frequent in the 15th and 17th centuries (Camuffo et al., 2003).

\subsection{Flood change detection - challenges and opportunities}

The reviews of change detection methods (Sect. 2.1) and flood regime changes in Europe (Sect. 2.2) have shown the potential of the methods and the data available to date. How-

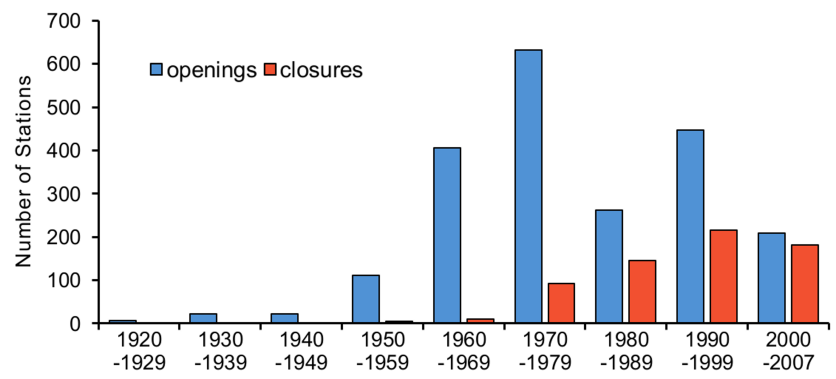

Figure 6. Evolution of the England and Wales stream gauging network. Number of gauging station openings and closures per decade (re-drawn from Hannaford et al., 2012).

ever, there are still challenges associated with these methods, though there are also opportunities for better understanding flood regime changes.

\subsubsection{Observation biases and data opportunities}

Any change detection relies not only on robust methodologies for data analysis but also on the available database. Flood data from the instrumental period may not always be accurate, particularly for large discharges, due to problems with the rating curves and stream gauge failure. Additionally, the time period for which flood data is available is equally important, as the presence or absence of instrumental data may lead to observation biases and may disproportionately influence the outcome of change analyses. For example, hydrometric monitoring networks were often installed in response to recent floods or recent droughts, which causes such extreme periods not appear in the observational data.

This can be seen in the UK and Ireland, where the gauging network expanded from the 1970s onwards, a period with drought conditions and particularly few floods which is considered to influence the outcomes of trend analyses performed (Hannaford and Marsh, 2008; Murphy et al., 2013; Prosdocimi et al., 2014). Another factor resulting in similar biases are changing societal priorities and/or financial constraints, which sometimes cause gauges to be closed down (e.g. Fig. 6). Other examples of observational biases can be seen in Italy, where the number of stream gauges declined sharply in the 1970s when the national hydrological service was split into regional services. Diakakis et al. (2012) also illustrated another type of observational bias for the case of Greece where an apparently increasing number of floods over the last few decades were related to more detailed reporting on floods. The bias in the perceptions of flood occurrence and the contribution of changes in media coverage is also evident in other studies (Barnolas and Llasat, 2007b; Lara et al., 2010).

For historic flood data, observation bias may be even more important. Generally, the further one goes back in history the fewer documentary sources or measured data are available. Smaller floods can be overlooked since, usually, only 
floods that caused loss of life or material damage were considered important enough to be recorded. The observation bias is particularly challenging when historical records are used for flood frequency analysis.

There are two principal approaches to compensate for missing pre-instrumental data. The first is the selection of a time frame over which the largest events are likely to have been recorded (Parent and Bernier, 2003; Macdonald et al., 2006, 2013). The second approach is to include only a fixed number of events above a perception threshold (Stedinger and Cohn, 1986; Viglione et al., 2013).

It is usually difficult to estimate flood discharges from flood marks (water levels), particularly if the stream morphology has changed over time or buildings with epigraphic marks have been rebuilt. However, not only pre-instrumental discharges are important but also the number of floods exceeding a threshold are valuable for flood frequency analysis. For example, Viglione et al. (2013) noted that the number of floods exceeding a threshold is a more important piece of information than the discharges themselves.

It is also challenging to estimate the water levels themselves from documentary sources due to the descriptive character of historical flood reports, often related to the impact such events have had, which may have changed (usually increased) over time for the same flood discharge (Brázdil et al., 2005). It is therefore important to isolate, as best as possible, flood impacts and the flood severity.

Given these potential observation biases, extending documentary and instrumental records by various methods can be an opportunity to overcome some of the associated limitations. Streamflow may be reconstructed by using historical information (e.g. Macdonald and Black, 2010), by infilling short broken flow records with the help of rainfall runoff models, when longer precipitation records are available (Murphy et al., 2013), and by using donor stations, where neighbouring stations are employed to develop regressions with target stations for infilling (Merz and Blöschl, 2008a, b; Harvey et al., 2012). Historic flood marks on houses and bridges can be used to compile quantitative flood chronologies and extend systematic records. For example, water marks of the Elbe floods can be found on the castle rock in Děčín, and water marks of the Vltava floods in Prague are indicated by the Bearded Man (Bradáč) (Brázdil et al., 2005), which can be used to estimate peak discharges (Elleder et al., 2013). The combination of documentary and epigraphic information on floods with other proxy flood records, such as floodplain or lake sediments, offers the opportunity to corroborate the non-instrumental evidence against each other and to extend the flood series further in time (Werritty et al., 2006). Proxies such as weather classification schemes can also be used to reconstruct drivers of fluvial flood occurrence to assist in interpreting the flood records (e.g. Wilby and Quinn, 2013).

\subsubsection{Observational window, flood trends and flood-rich/flood-poor periods}

The previous sections on methods used to detect flood changes, have indicated that the currently prevailing paradigm of analysing systematic flood data is trend analysis. In contrast, historic flood data are typically screened for flood-rich and flood-poor periods. In fact, when performing trend analysis there is an implicit assumption that the change as indicated in Fig. 2 is covered fully by the observational period. In reality, very often, the flood regime fluctuates over decades and centuries as highlighted in the review of the historic flood data. If the timescale of variability is longer than the observation period, oscillations can look like a trend (Blöschl and Sivapalan, 1995; Koutsoyiannis and Montanari, 2007; Chen and Grasby, 2009). This point is illustrated in Fig. 7. If only the instrumental data (dark blue colour) are available (Fig. 7a) an increasing trend will be detected. If the data set is extended back in time (Fig. 7b) it becomes clear that the concept of a trend is not useful in this case. Instead, it is more appropriate to consider the existence of flood-rich and flood-poor periods.

The existence and identification of flood-rich and floodpoor periods also has implications with regard to the flood prediction and design values for flood protection works, as such estimates would then have to be considered as dependent on the reference period. It is therefore suggested that future flood change analyses of systematic data should actually focus on identifying flood-poor and flood-rich periods instead of only detecting whether trends exist. Trend analysis alone can be misleading as the results invariably depend on the observational window and homogeneity of the flood series.

This strong dependants on the observational window becomes particularly apparent when multiple windows of various record length (minimum $30 \mathrm{yrs}$, with varying start and end dates) of long-term flood records are analysed, as shown for two examples in Fig. 8. From the graph it becomes apparent that there is an overall tendency of decreasing flood trends for the River Vltava, some of which become statistically significant at the $5 \%$ level for series ending around and after 1960 (depending on the start date selected). The annual maximum floods at Prague were particularly high in 1845, 1862, 1872 and 1890; afterwards there was a decrease in flood magnitudes, particularly for winter floods (Brázdil et al., 2005). Low flood magnitudes are typical of the second half of the 20th century, which partly coincides with the construction of several reservoirs along the river upstream of Prague, the so-called "Vltava cascade". The effect of the August 2002 flood, the biggest flood of the instrumental record, is also evident. In contrast, the Danube tends to show increasing trends, particularly if the most recent floods are included.

It is important to note that these analyses test the trends in the mean flood of the records; mean floods and extreme floods do not necessarily exhibit the same time patterns. 

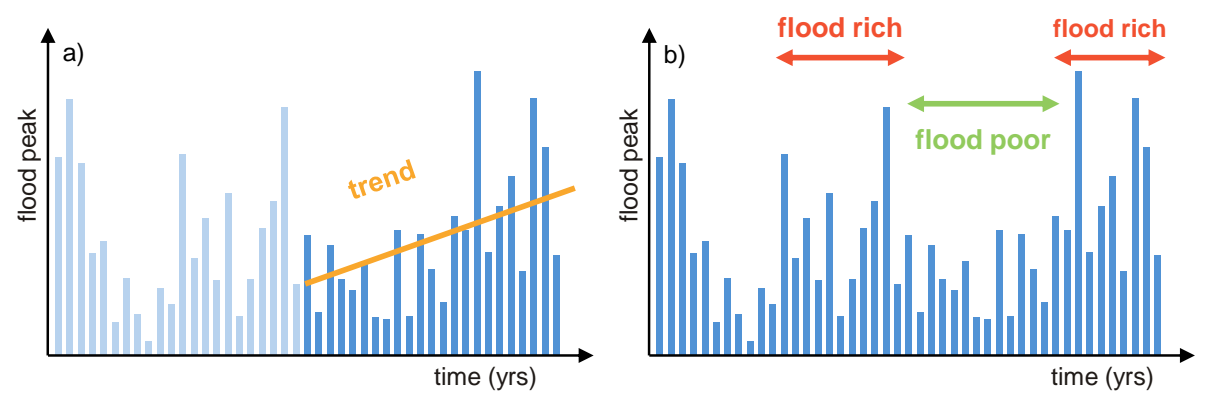

Figure 7. Evaluation of flood peak changes over time. (a) Monotonic trend analysis; (b) identification of flood-rich and flood-poor periods. Dark blue colour indicates data available for analysis.

Indeed, for the Danube the small and medium floods have increased for some of the periods due to increased precipitation and the loss of retention areas (Blöschl et al., 2013a, b), while there is no evidence of trend in the extreme floods (Blöschl and Montanari, 2010). This suggests that changes in extreme floods should be tested separately from changes of the mean. However, as pointed out by Frei and Schär (2001) the detection probability of extreme events is much lower than that of the mean. In addition, the greater the variability of a series compared to the change signal, the more difficult it is to detect a trend (Wilby, 2006). This means that small changes in the flood regime may be masked by the underlying generic variability.

\subsubsection{The Hurst phenomenon and nonlinearities}

An interesting aspect concerning the temporal variability of floods is that they tend to cluster in time, which is a phenomenon that can be observed in most records around the world. This tendency of hydrological series to cluster was first recognised by Harold Edwin Hurst for the Nile River (Hurst, 1951). While the phenomenon of flood series to cluster into flood-rich and flood-poor periods is not fully understood, it is thought to be related to climate-ocean oscillations or persistent long-term memory of hydrological processes (Montanari et al., 1997; Markonis and Koutsoyiannis, 2012; Montanari, 2012). It implies significant uncertainty in the flood regime change detection because of the large variability of regime change at many timescales.

There are several techniques for detecting the Hurst phenomenon in time series, ranging from heuristic techniques, maximum likelihood estimators and spectral methods (Montanari et al., 1999; Szolgayová et al., 2014). However, from flood data alone, it is difficult to attribute the Hurst phenomenon to either natural cycles or human-induced changes. Additional information on the climate, e.g. the North Atlantic Oscillations (Walker and Bliss, 1932), and other controls may be needed. Overall, the identification of flood-rich and flood-poor periods should be preferred over trends, as they are consistent with the presence of the Hurst phenomenon.
Identification of flood-rich and flood-poor periods can be based on linear methods such as spectral decomposition. However, if the controls are nonlinear, linear analyses may lead to inconclusive results and the signal may be misinterpreted as noise. Instead, nonlinear time series analysis tools (e.g. embedded phase space reconstruction, Nicolis and Nicolis, 1984; Abarbanel, 1996) may provide signatures of the underlying dynamics that are more readily interpretable. When the degree of nonlinearity in the flood data and their drivers is not clear, information-theoretic diagnostic tools can be invoked to identify nonlinearity and non-normality (Pires and Perdigão, 2012, 2013), and address the nonlinear and non-normal response of regional-scale flood regimes to synoptic-scale climate patterns (Pires and Perdigão, 2007).

Equally important as the statistical methods are deterministic methods to explain the presence of flood-rich and floodpoor periods. One approach is to identify the features of the underlying system from the flood record, including structural stability, degree of complexity (i.e. number of drivers) and overall phase space structure (possible states assumable by the system, e.g. flow characteristics and underlying mechanisms). The time series of a single variable contains implicit information from other variables, whose contribution can be retrieved by phase space reconstruction (Nicolis and Nicolis, 1984; Abarbanel, 1996). Geometric properties of the phase space may indicate the presence of regimes such as flood-rich and flood-poor periods. Identifying potential flood-rich and flood-poor stable regimes could then lead to a better understanding of why the system would be locked in such regimes for several years.

\section{Scenarios: predicting future changes in floods}

\subsection{Methods of scenario analysis}

Unlike the change detection based on systematic and historic flood data presented before, the scenario approach links flood changes to their causal processes based on flood simulations. Usually, a statement is made about possible future flood changes and their reasons. Sometimes the approach is 

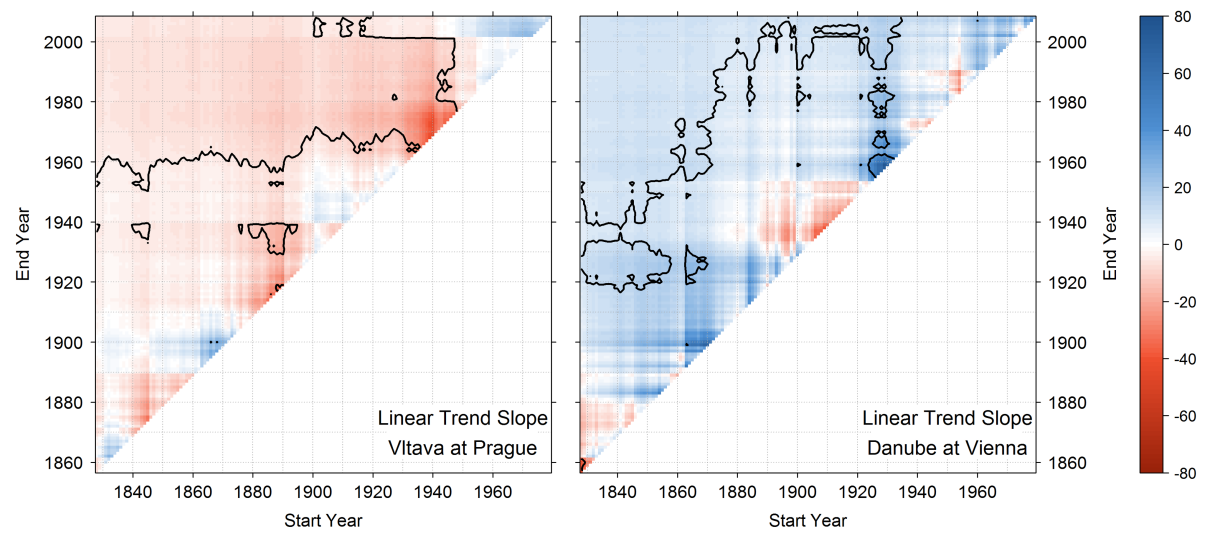

Figure 8. Trends derived from linear regression of the annual maximum flood series for the Vltava at Prague (left panel, $\sim 26700 \mathrm{~km}^{2}$ ) and the Danube at Vienna (right panel, $\left.\sim 101700 \mathrm{~km}^{2}\right)$. Regression slopes $\left(\mathrm{m}^{3} \mathrm{yr}^{-1}\right)$ are derived from moving windows for all possible combinations of start and end years between 1828 and 2008 (with a minimum series length of 30 yrs). Blue colours indicate increasing trends, red colours decreasing trends. The black line encloses combinations of start and end years with significant trends at the $5 \%$ level (predominately long series on the top left).

also used to understand past flood changes better. In most instances, two groups of cases are compared: (i) the present, and (ii) possible futures. The differences between the two then sheds light on changes in the flood regime.

The modelling of the scenarios represents knowledge about the causative mechanisms of how hydraulic structures, land use and climate affect floods. Since rainfall and snowmelt are the main drivers of river floods, the simulations invariably involve hydrological models to translate the rainfall/snowmelt input into catchment runoff and consequently flood changes. Sometimes runoff from an upstream catchments is directly used as model input for a downstream location.

While the typical application of the scenario approach is to make statements about the future, the representations of the causative mechanisms should ideally be founded on hydrological knowledge obtained in the past. This is because the modelling does not only involve balance equations of mass, momentum and energy but also empirical formulations of the model structure, model parameters, and boundary conditions. Knowledge of past flood change mechanism is therefore essential for building realistic models and scenarios.

The term "scenario" is often used loosely in the environmental sciences. It is therefore useful to recall the original concept of the scenario approach. Scenario analyses were adopted by the corporate world from the late 1960s onwards (Van Der Heijden, 1996). The challenge was that the predictions needed for planning were often highly uncertain. The idea of the scenario approach was to separate what is predictable from what is not predictable. Following that idea, the scenarios, representing different possible futures, should differ in terms of what is not predictable, but the predictable aspects should be identical in all of them. The scenarios could then be used to test policies and plans to assist robust decision making. As Van Der Heijden (1996, 17-18) noted, "the first objective of scenario planning became the generation of projects and decisions that are more robust under a variety of alternative futures $[\ldots]$. Better thinking about the future became the second objective of scenario planning."

The present usage of the term "scenario" in hydrology and related disciplines is slightly different and is often taken as a synonym for a forecast or a number of alternative forecasts each of which includes (rather than excludes) the main uncertainties. Often the term "projections" is used to highlight that a range of alternative futures is represented (Niehoff et al., 2002), but it is not always clear what they actually entail. In the context of climate sciences, the terms "prediction" and "projection" are explicitly distinguished, depending upon whether an attempt is made to include predictions of internal variations (e.g. IPCC, 2013).

It is suggested here that there is a gradual transition between forecasts/predictions/projections and scenarios (in the original sense), and between predictions/forecasts and projections (in the sense of the IPCC), depending on where the main uncertainties are placed. If they are captured within one scenario, it is appropriate to talk about forecasts (or predictions); if the scenarios differ by the main uncertainties then it is appropriate to talk about a scenario approach in the original sense. Overall, it would be useful to be more explicit about the nature of the statements about the different futures, their predictable and unpredictable aspects and associated uncertainties that are made when using a scenario approach.

Below, the main methods used for understanding the causative mechanisms of flood change effects: in or near the stream (hydraulic structures and stream morphology), in the landscape (land use), and of atmospheric processes (climate change) are briefly reviewed. 


\subsubsection{Rivers: hydraulic structures and stream morphology}

Changes of the flood regime resulting from streambed and floodplain processes are mainly associated with river training works: the construction of hydraulic structures such as levees, polders or retention basins, and changes of the streambed or the floodplain morphology, resulting from aggradation raising of the streambed by deposition of stream sediment -, or degradation when sediment supply is less than the transport. In the scenario approach, usually, cases representing the present are compared with those representing the future. In some instances, it is also of interest to represent the situation in the past before some structures have been installed.

Given the focus on the river and the floodplain, the main component of the scenario simulations is a hydrodynamic model. These models are based on the equations representing conservation of mass and momentum in the fluid (the Navier-Stokes equations) which are solved numerically for pressure and flow velocity by finite difference, finite volume or finite element methods (see Krámer and Józsa, 2004 and Alcrudo, 2002 for overviews). To this end, the domain needs to be discretised in both space and time. To increase the numerical efficiency, the Navier-Stokes equations are usually integrated vertically to form the two-dimensional shallow water equations, in which case the hydrodynamic model represents a two-dimensional rather than a three-dimensional domain.

In setting up the hydrodynamic model, a number of issues need to be considered.

\section{(i) Numerics}

First, the numerical schemes need to be stable, accurate and conserve mass and momentum (e.g. Murillo et al., 2007). In the case of floodplain inundations, this is a non-trivial task to achieve since the wetting-drying transitions tend to cause numerical instabilities. A number of methods have been developed to provide stable solutions (e.g. Brufau et al., 2002; Zokagoa and Soulaïmani, 2010). It is important to test the model code against benchmark data sets such as analytical solutions in order to ensure the suitability of the code (e.g. Liang and Marche, 2009; Zokagoa and Soulaïmani, 2010).

\section{(ii) Geometry}

In a second step, the geometry of the terrain needs to be specified. This is usually done based on airborne lidar (light detecting and ranging) techniques that produce a detailed digital terrain model. Additionally, any hydraulic structures and operation rules of hydraulic gates need to be included.

\section{(iii) Parameters}

The third step is to set the model parameters. The main parameters are related to different streambed and flood plain roughnesses, which can vary in space and time. The hydraulic resistance of submerged vegetation may exhibit complex patterns which are not fully understood and represent an active area of research (Stephan and Gutknecht, 2002; Green, 2005; Nepf, 2012). In addition, the roughness of the streambed may change depending on the sediment size distribution (Fischer-Antze et al., 2008). Roughnesses are usually obtained by calibration, i.e. varying the roughness values until the hydrodynamic model reproduces the observed water levels and/or inundation areas of a particular river reach or floodplain (Grayson et al., 2002). Unfortunately, calibration is not always possible for the largest floods of interest, as observation for such extreme events are often missing. In that case, roughness is usually estimated from smaller floods or similar floodplains, where observations are available, but this procedure adds additional uncertainties. Roughness can also be estimated by alternative methods, such as interpreting high-resolution lidar data (Hollaus et al., 2011; Vetter et al., 2011). However, due to the estimation procedure some level of calibration may still be needed.

\section{(iv) Behaviour of hydraulic structures}

Another issue that needs to be considered is the behaviour of levee failure. While, strictly speaking, soil mechanical models are appropriate for modelling the occurrence of levee failure, usually simplified probabilistic representations are more suitable to examine dam failures in the context of the flood regime (e.g. Apel et al., 2004, 2006). Additionally, operation rules of hydraulic structures need to be included, where appropriate, to represent the effect of their management strategies (e.g. Ahmad and Simonovic, 2000).

\subsubsection{Catchments: land use and land cover}

The effects of land use and land cover changes on runoff- and flood-generating processes can be presented in a scenariomodelling approach similar to changes induced by hydraulic structures and stream morphology. The evolution of vegetation and soils is usually strongly interlinked through macropore formation, nutrient cycling and other processes (Markart et al., 2004), so changes in the land use or land cover may lead to changed infiltration characteristics, which may have significant effects on the flood regime.

Land use and land cover changes such as deforestation/afforestation or urbanisation are usually represented in the hydrological models through changes in the model parameters (Brath and Montanari, 2000). In fact, the essential step in scenario modelling is to choose appropriate model parameters for changed land use or land cover, in particular those controlling infiltration. Finding parameters for changed 
conditions is a very similar problem to finding parameters in ungauged basins (Blöschl et al., 2013c) where, similarly, model parameters need to be estimated without calibration to streamflow data. Depending on the model and data availability, various parameterisation strategies have been used.

There are three generic options for obtaining the parameters.

\section{(i) A priori estimates of the parameters from field observations}

Infiltration model parameters such as the saturated conductivity, porosity and soil water release characteristics can be estimated from plot-scale infiltration experiments or from laboratory analyses. Alternatively, pedotransfer functions can be used to estimate such parameters from soil texture (Wösten et al., 2001) with the limitation that soil texture usually cannot fully represent land use/cover effects. This method is particularly amenable to process-based hydrological models as the changes in land cover characteristic can directly be accounted for by changing the soil or vegetation parameters in the model lookup tables.

\section{(ii) Paired catchment studies}

An alternative are catchment scale experiments where runoff from two neighbouring catchments are monitored together, and at some stage the land use/cover is changed in one of the catchments. The differences in the flood characteristics then allow inferring the differences in the hydrological model parameters. This approach is appealing and useful as it captures catchment-scale processes, but the relationships between land use and flood changes tend to be complex and are not always well defined (Bronstert et al., 2002; Robinson et al., 2003; Andréassian, 2004; Brown et al., 2005).

\section{(iii) Trading space for time}

The idea of this approach is to estimate infiltration parameters at different locations of the landscape of interest using distributed hydrological models. The approach is based on the assumption that the spatial parameter differences for different land units are directly applicable to temporal differences as a result of changed land use at the same location. A typical method is to define hydrological response units (HRUs) on the basis of land use and soil type and estimate the model parameters from streamflow and other hydrological characteristics (Blöschl et al., 2008; Hundecha et al., 2008; Samaniego et al., 2011; Arheimer et al., 2011). This method is particularly suitable for conceptual hydrological models (for a summary see Blöschl et al., 2013c and Parajka et al., 2013). However, a drawback of the method is that one usually assumes that the spatial differences in soil parameters apply immediately to the location where land use has been changed, while soils can take decades to respond to land use changes (Runyan et al., 2012).
There is a wide range of hydrologic models available for simulating land use and land cover changes, however for a robust scenario-modelling approach the model structure and parameterisation need to account for various factors and feedbacks associated with the change. Models need to be able to link land use/cover, soil characteristics and unsaturated zone dynamics that control the infiltration process, account for the temporal and spatial dynamics of the rainfall-runoff process, and consider initial conditions of the flood event, in particular antecedent soil moisture (Niehoff et al., 2002) in the case of event models.

Land use/cover scenarios may assess historical changes in the catchment - as for example by comparing flood responses in the Oder Basin, associated with different land use scenarios, namely land use derived from historical maps from 1780 with that of 2001 (De Roo et al., 2003). De Roo et al. represented afforested areas by increased interception and urbanised areas by zero infiltration in the model. Scenarios can also relate to future, hypothetical changes. Niehoff et al. (2002) assigned hypothetical changed land use categories to each grid cell of a catchment model in a spatially explicit manner and analysed the effect of increasing urban extent on flood volume and peaks. In a similar manner, Salazar et al. (2012) assessed the effect of afforestation on the flood regime in three middle-sized catchments in Spain, Germany and Austria. A more process-based assessment of hypothetical land use change effects is presented by Naef et al. (2002). By selecting the four main dominant runoff processes in a catchment (i.e. infiltration excess and saturation excess overland flow, shallow lateral subsurface flow and deep percolation) they were able to separate different effects on floods in terms of the location and spatial extent of the dominant processes. They stressed that a reduction of storm runoff by changing land use/cover and management practices is only feasible for catchments where infiltration and matrix wetting can be enhanced through such measures.

The examples presented above illustrate that a robust interpretation of land use scenario modelling requires simple but process-based model structures that are able to account for the main features of soil-vegetation-atmosphere interactions.

\subsubsection{Atmosphere: climate}

Changes in the climatic system and their effects on floods are commonly explored using climate change scenarios due to the strong climate-flood linkages. Such climate change scenarios represent a cascade of atmospheric processes, from the global scale (different greenhouse gas and aerosol emission scenarios to drive global climate models, GCMs), to the regional scale, which are then used as input to hydrological models that simulate the flood regime.

From a flood hydrology perspective, the essential steps in the procedure are (i) atmospheric modelling and downscaling from the global to the regional scales, (ii) correcting 
any biases of the outputs of the atmospheric model, and (iii) the hydrological modelling of the flood regime (Raff et al., 2009).

\section{(i) Atmospheric modelling and downscaling}

Downscaling is used to bridge the gap between the grid scale of GCMs $(\sim 100 \mathrm{~km})$ and the much smaller hydrological scale (Cohen, 1990). Dynamical downscaling approaches consist of nesting a regional climate model (RCM) into the GCM to represent more accurately surface topography and other land surface characteristics, and yield a better approximation of the atmospheric energy-cascade including the formation of precipitating systems, fronts and rainbands. An alternative is statistical downscaling where relationships are established between one or more large-scale variables provided by the GCMs (predictors, such as pressure) and the observed local surface variables (predictands, such as precipitation) (Wilby et al., 1998; Giorgi and Mearns, 1999; Wood et al., 2004; Blöschl, 2005; Chen et al., 2011). In addition, combinations of the two approaches are possible.

For Europe, large sets of RCM simulations using a wide range of different GCMs and RCMs are available with horizontal resolutions of 50, 25 and $12 \mathrm{~km}$ (Christensen and Christensen, 2007; Van der Linden and Mitchell, 2009; Jones et al., 2011). While they do not explicitly represent convective precipitation and associated feedback processes, which are important for the European summer weather, it is expected that within a decade new scenarios with explicit convection at horizontal resolutions of around $1 \mathrm{~km}$ will become available (Hohenegger et al., 2008, 2009).

\section{(ii) Bias correction}

Correcting biases of the outputs of atmospheric models is important as the biases tend to be large and hydrological flood model output shows sensitivity to them. In applying bias correction methods, it is usually assumed that the model biases of the past climate will remain the same in the future (Teutschbein and Seibert, 2013), although it is not possible to check this assumption directly. Relationships between observed and simulated precipitation (and other climate variables) are therefore estimated for the reference period in the past and applied to the future.

The bias correction methods differ in how these relationships are defined:

- Local intensity scaling: a linear relationship between observed and simulated precipitation is defined for precipitation intensities larger than a threshold. The threshold is selected in a way to match observed and simulated wet day frequencies and the slope of the relationship is selected to match mean monthly precipitation (e.g. Schmidli et al., 2006).
- Nonlinear correction: a power law relationship between observed and simulated precipitation is assumed and the parameters are estimated to match observed and simulated mean monthly precipitation as well as the coefficient of variation of daily precipitation (Teutschbein and Seibert, 2012).

- Distribution mapping (also quantile-quantile mapping): this is a non-parametric method in which the distribution of the simulated precipitation is transformed to match the distribution of the observed precipitation (e.g. Yang et al., 2010).

Teutschbein and Seibert (2012) and Chen et al. (2013) noted that the selection of the bias correction method can have a major effect on the flood simulations. They recommend distribution mapping because of its ability to generate realistic statistical characteristics, particularly for extreme events. However, bias corrections are sensitive to the reference period, the sampling of the seasonal cycle (Bosshard et al., 2011), and do not usually account for cross-correlation between temperature and precipitation and for changes in the temporal structure of precipitation (Dahné et al., 2013; Donnelly et al., 2013), which may be relevant for flood simulations.

\section{(iii) Hydrological modelling}

Hydrological modelling generally assumes stationarity of the model parameters and the model structure. Merz et al. (2011) noted that this assumption might constitute an important oversimplification. They calibrated a conceptual rainfall runoff model to six consecutive 5-year periods for numerous catchments in Austria and found significant temporal changes in the calibrated parameters representing snow and soil moisture processes, which led to biases in high flows of more than $30 \%$. They therefore recommended testing model stationarity based on the hydrological data of past decades.

In terms of the hydrological modelling setup, one can proceed along one of three avenues:

- Direct use of atmospheric model output: climate model output for past and future periods are directly fed into a hydrological model. In this approach, the use of downscaling and bias correction procedures is particularly important, as the raw model output generally lacks the appropriate statistical characteristics. If the biases of the atmospheric model (in particular for precipitation extremes) are small, the first method (direct use of the atmospheric model output) is a prudent choice as it can account for changes in the temporal structure of precipitation. If the biases are large, the bias correction method may introduce artefacts into the analysis (Teutschbein and Seibert, 2012). 
- Delta-change methodology: the climate change signal is extracted from a pair of control and scenario simulations. The hydrological scenarios are then obtained from two hydrological model simulations, one driven by observed data, the other driven by the same observed data with the climate change signal superimposed. This approach is straightforward and widely used, but it retains the variability of the observed climate time series used.

- Use of weather generators: instead of using only observed climate data, one can use output of weather generators (multivariate stochastic models) that have been calibrated to observed climate data and modified for the scenarios. The use of such approaches is widespread in single-station applications, but more difficult when both temporal and spatial consistency is required, as in many hydrological scenarios. They are particularly appealing for flood scenarios as they allow reliable representation of the higher-order statistics of precipitation extremes (i.e. the shape of the extreme value distribution).

\subsection{Flood change projections in Europe}

This section reviews possible changes in future flood regimes supported by process understanding and existing causalities presented by models that can be related to hydraulic structures and stream morphology (Sect. 3.2.1), land use and land cover (Sect. 3.2.2) and climatic change (Sect. 3.2.3). For Sects. 3.2.2 and 3.2.3 the findings have been organised by the hydro-climatic regions in Europe (shown in Fig. 3), as the changes are related to the spatial distribution of climate and landscape characteristics. For Sect. 3.2.1 this is not the case as local changes to rivers are much more important. The findings are therefore discussed by the type of river modification.

\subsubsection{Rivers: hydraulic structures and stream morphology}

Europeans have altered their rivers for hundreds of years (Gurnell and Petts, 2002). The main motivations have been to secure navigation, flood protection and, more recently, hydropower operation as well as environmental restoration. Below, past and anticipated effects of modifications of the river and the floodplain are discussed by river training, floodplain removal, retention basins and other changes. Figure 9 shows a schematic of the associated changes of the flood regime. As indicated in the figure, the effects on the flood discharges, typically, depend on the magnitude of the floods.

\section{(i) River training}

River training involves straightening meandering or braided rivers. As the modifications relate to the channel itself, the effect on the flood magnitudes is largest as long as the flood- waters stay within the riverbed. This implies that the impact of river training activities on the flood peaks typically decreases with the magnitude (or return period) of the floods as indicated in Fig. 9a.

Lammersen et al. (2002) and Bronstert et al. (2007) suggested that, for large rivers, river training measures (e.g. construction of weirs or flooding of polders) might affect floods at a similar level or larger than past changes in land use. Vorogushyn and Merz (2013) recently applied homogenisation relationships (based on flood routing models) to the discharge records of the Rhine River (Germany) and several tributaries for the period 1950-2009, to produce scenarios of homogenised series of annual maximum flows that could occur if the river training measures of the Rhine were not in place. Based on the comparison of original and reconstructed flood series, they showed that river training had caused a systematic superposition of flood waves of the Rhine and its tributary, the Neckar River, which had increased the annual maximum floods by about $10 \%$.

\section{(ii) Floodplain removal}

Floodplain removal by building levees will affect the flood regime once the floodwaters inundate the floodplains. Because of this, floodplain removal typically affects the flood peak volume of intermediate floods (Fig. 9b). For very large return periods, when the levees are overtopped or breaches occur, the effect becomes relatively less important.

The modelling study of Di Baldassarre et al. (2009) at the River Po (Italy) found that the increase in high water levels in the past decades was mainly due to the heightening of the levee system, as previously hypothesised by Marchi et al. (1996). For the Danube, Blöschl et al. (2013a, b) noted that during the September 1899 flood, approximately $1000 \mathrm{~km}^{2}$ of floodplain along the Danube and tributaries were inundated, whereas only a few $100 \mathrm{~km}^{2}$ of floodplain storage were available during the June 2013 flood, which had significant effects on the flood peak discharges. Floodplain removal may also increase the celerity of the flood waves as shown for the Danube by Mitková (2002) and Blöschl et al. $(2013 \mathrm{a}, \mathrm{b})$ and for the lower Morava by Szolgay et al. (2008).

Current river restoration efforts aim to remove or push back levees in order to offer more space for natural river dynamics and thus reduce flood peaks. Hooijer et al. (2004) and Bronstert et al. (2007) concluded that upstream water retention measures in the Rhine Basin could significantly reduce the frequency of small and intermediate floods in small basins, and contribute to the reduction of medium floods in large basins. However, no significant effects were noted for extreme floods in large basins and downstream areas. In these restoration measures, riparian vegetation can be planted to increase roughness. These increases in the roughness may increase the local water levels, but their downstream effects tend to be very small, as the main control on flood peak 

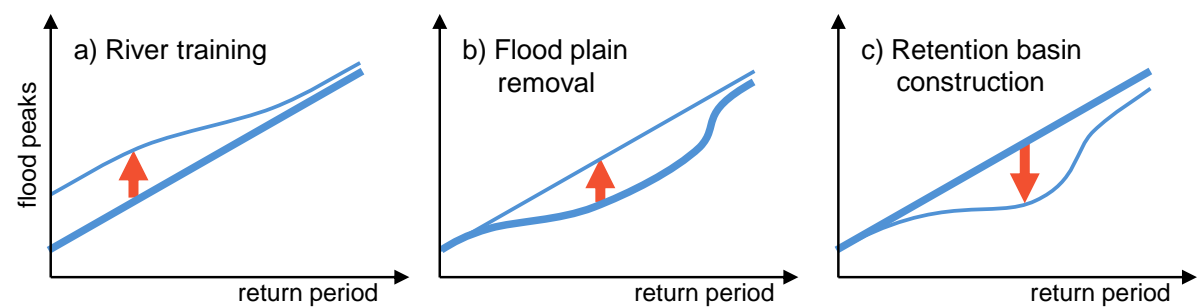

Figure 9. Hypothesised impact of three types of hydraulic engineering activities on the flood frequency curve. (a) River training tends to increase the small floods. (b) Removing floodplain storage by constructing levees tends to increase the medium-sized floods. (c) Constructing retention basins tends to reduce the medium-sized floods.

attenuation is the volume of water stored on the floodplain at the time of the peak, relative to the flood wave volume (Valentová et al., 2010).

\section{(iii) Retention basins}

Retention basins tend to have a similar effect as restoring retention volume on floodplains (Fig. 9c). Their effect is largest for medium-sized floods for which the retention basins have been designed. The effectiveness is usually calculated as part of the planning process of the retention basin.

Important for their effectiveness is the timing when they are filled as illustrated by the comparative study of Salazar et al. (2012) in three middle-size catchments in Spain, Germany and Austria. If the retention basins are filled too early, at the beginning of the event, their effectiveness may significantly diminish. This is also the reason why unregulated microponds located in the landscape are much less effective than regulated reservoirs along the stream (Salazar et al., 2012, also see Arheimer and Wittgren, 2002).

\section{(iv) Other changes to the river and the floodplain system}

For future flood changes, the effects of the rising numbers of reservoirs or dams built for hydroelectric power production are also important, particularly the effect of trapping of sediment in reservoirs (Vörösmarty et al., 2003; Nilsson et al., 2005; Syvitski et al., 2005). Sediment-starved rivers, which are often found below reservoirs, tend to degrade and narrow, while excessive sediment load leads to river bed aggradation, with adverse effects on the flood conveyance capacity. The feedbacks between floods and sediment transport and timescales of channel adjustment are complex but can be understood from an integrative catchment perspective, which includes the estimation of catchment sediment production, storage and transfer, as well as anthropogenic effects on these processes (e.g. Molnar et al., 2002; Syvitski, 2003).

The effects of hydraulic structures and modified stream morphology are quite well understood at the reach scale, and hydrodynamic models are used widely to predict the effects on flood magnitudes. At the scale of large river basins, the processes may combine in a nonlinear way, so assessing the effects is more complicated. Yet, with the implementation of the European Flood Directive (EU, 2007) it is becoming increasingly more important to account for the combined effects of all alterations within a river basin.

\subsubsection{Catchments: land use and land cover}

Europeans have also altered their landscapes for many centuries. The main motivations have been to produce arable land and, more recently, urbanisation as discussed in previous sections.

A number of recent scenario studies have examined the potential of future land use and land cover changes (mostly afforestation) for mitigating floods as well as the effects of future urbanisation on floods. The review of the most recent studies provided below are again summarised according to the hydro-climatic regions defined in Fig. 3.

\section{(i) Western Europe and northern Europe}

In the UK, a number studies have examined the effect of de-intensification of farming and the provision of storage through reactivation of floodplains or construction of onfarm storage ponds on flooding (Hulse et al., 2009; Wheater and Evans, 2009; Foresight Land Use Futures Project, 2010; Wilkinson et al., 2010; Jackson et al., 2013). At the field scale, O'Connell et al. (2004) and Jackson et al. (2008) project potentially large changes in flood volumes and peaks associated with de-stocking, tree planting and drainage management. However, the simulated effects were highly variable depending on when and where the change is implemented (McIntyre et al., 2014). In some specific examples, even the directions of drainage and the location of tree planting within the field made a substantial difference to the change in floods (Jackson et al., 2008). In the small catchments examined (up to $10 \mathrm{~km}^{2}$ ), afforestation may lead to a reduction of about $10 \%$ of median flood discharges (Bulygina et al., 2009, 2011). At larger catchment scales $\left(>10 \mathrm{~km}^{2}\right)$, the effects of land use changes on floods are generally small and highly variable (McIntyre et al., 2012). 
When clear-cutting two forested catchments in the order of one $\mathrm{km}^{2}$ in Sweden by 70 and $100 \%$, Brandt et al. (1988) observed runoff increases of $200 \mathrm{~mm} \mathrm{yr}^{-1}$. These findings were used for model parameterisation in scenario analyses at larger scales, showing that $10 \%$ clear-cutting increased the flow peaks by $5-10 \%$. Summer and autumn floods increased while snowmelt peaks could were either higher or lower, depending on clear-cut location in the catchment. Similarly, the effects of afforestation on floods can be dynamic, for example depending on tree maturity and forestry management practices (Robinson, 1998).

\section{(ii) Central Europe and eastern Europe}

Salazar et al. (2012) assessed the effectiveness of afforestation in flood peak reduction for three medium-sized catchments in Germany, Austria and Spain using scenario simulations. For the smallest floods, they simulated a $30 \%$ reduction, but the effect decreased with increasing flood magnitudes to a few percent. They also found that the land use change effect on floods was larger for dry antecedent soil moisture than for wet conditions.

Solín et al. (2011) correlated observed flood frequencies in small catchments in Slovakia for the period 1996-2006 with the associated land use changes. While significant land use changes occurred, these were not significantly correlated with flood changes. Long-term experimental forest research in the Czech Republic also showed that deforestation may be a less important control on flooding than climate, and the practical management of clearing forests (such as road and ditch construction) may play a larger role in changing floods (Bíba et al., 2006; Solín et al., 2011).

\section{(iii) Mediterranean}

A model linking land use in the Mediterranean region with climatic perturbances at the European scale has been developed and tested (Millán et al., 2005). They point out that surface drying due to land use changes such as deforestation results in a local-to-regional vertical recirculation over the Mediterranean Sea. This leads to a decreasing trend and local loss of summer storms and summer floods but also results in more frequent flash floods in autumn in the Western Mediterranean. Additionally, the model showed that accumulated water vapour over the sea participates in major precipitation events, and flooding episodes in other parts of Europe.

The comparison of two land use maps of the Mella River basin in northern Italy by Ranzi et al. (2002), showed an increase in the forested areas in the upper part of the basin and in the urban development in the valley, resulting in a decrease of the cultivated areas during 1954-1994. The surface runoff, derived from a distributed hydrological model, changed insignificantly at the catchment scale, but with slightly reduced flood peaks and volumes under current land use conditions, due to the increased water storage in forested areas, which offset the expansion of urban areas. From their scenario analysis, Brath et al. (2006) conclude that the effects of land use change on the Bologna district, in Northern Italy (1955 and 1992) are not significant for the natural river network, while they are significant for the artificial drainage networks with locally modified river geometry.

\subsubsection{Atmosphere: climate}

Changes in the global climate and individual climatic variables can affect floods in various ways, together with soil moisture and snow storage. Generally, a warmer atmosphere can hold more water vapour (Huntington, 2006), which may increase heavy precipitation and therefore floods.

Similar to floods, rainfall extremes tend to exhibit temporal clustering at multi-decadal timescales. For example, Willems (2013) found that, in Brussels, extreme rainfall intensities were particularly high during the 1960s and the 1990s-2000s for timescales from 10 min to 1 month. Warmer air temperatures will also lead to earlier snowmelt and shifts in the role of snowmelt and rain-on-snow floods, particularly for high-altitude catchments (Bosshard et al., 2014).

RCM simulations suggest that for the period 2070-2099, as compared to 1970-1999, mean precipitation and wet-day frequency will increase in northern Europe, and decrease in southern Europe (Rajczak et al., 2013). These patterns can be found in all seasons, but are shifted further north in winter, and further south in summer. Projected changes in extreme precipitation exhibit a similar pattern, but increases in heavy events reach further south. For instance, during spring and autumn, much of the Mediterranean is projected to experience decreases in mean precipitation but increases in extreme events. Additionally, regional warming can lead to patchier and more convective precipitation. Seneviratne et al. (2012) suggest that there is a strong regional dependency of the projected changes and larger uncertainties in the South than in the North of Europe.

Overall, most of the published work relates changes in climate to mean annual or seasonal runoff, whereas impact studies on high flows and flood are less frequent. Figure 10 provides an example of one of the possible change projections for Europe, but other studies are not necessarily consistent with these projections. The regional projections provided below are summarised according to the hydro-climatic regions shown in Fig. 2.

\section{(i) Western Europe and northern Europe}

For Atlantic western Europe, Lehner et al. (2006) and Rojas et al. (2011) project that today's 100-year floods will become more frequent by the 2070s, but with regional differences in the change, but for Atlantic France decreasing (Lehner et al., 2006; Dumas et al., 2013) and increasing (Rojas et al., 2011) frequencies are projected. The general tendency for the 100year flood to become more frequent in western Europe has 


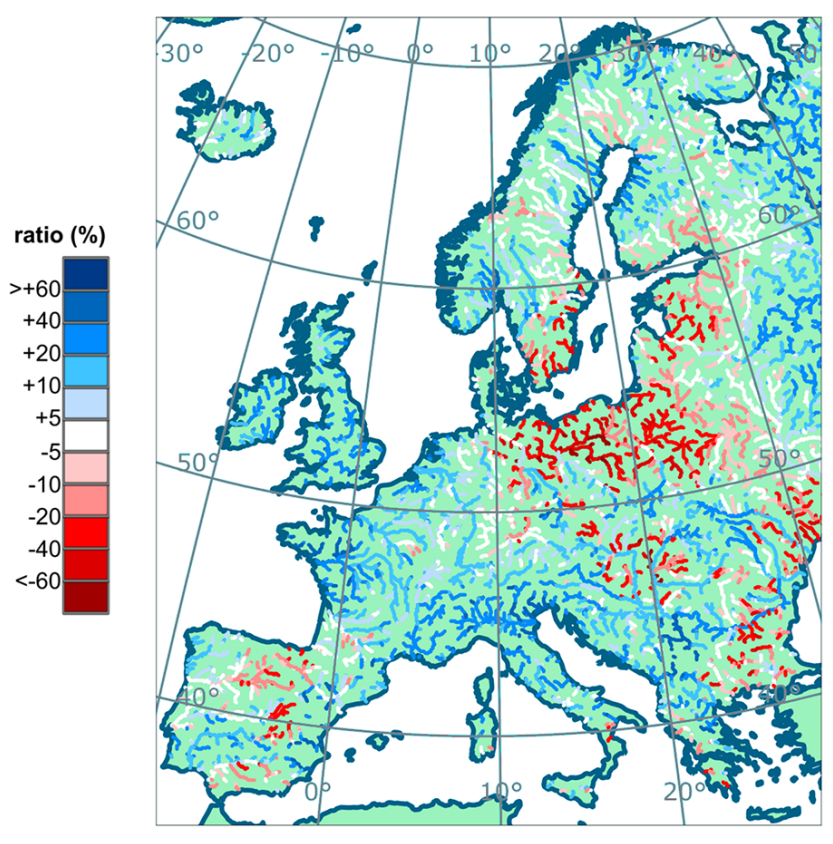

Figure 10. Example of estimated ensemble average change in the 100-year flood discharge between 2071-2100 and 1961-1990 (Rojas et al., 2012). Note that other studies are not necessarily consistent with these projections.

also been suggested by Hirabayashi et al. (2008) and Dankers and Feyen (2009).

In Portugal, the flood magnitude and frequency are projected to increase by the end of the century (Santos et al., 2002). In northern France, no significant change in the 100year floods are projected for the 21st century (Ducharne et al., 2011), whereas at a national level, results suggest an unclear evolutions of flood characteristics (including magnitude and duration) in France (Chauveau et al., 2013). Flood frequency was projected to increase in Belgium for catchments with dominating surface flow (Gellens and Roulin, 1998).

For the British Isles, floods are generally projected to increase. Winter floods with high return periods in Ireland are projected to occur more often in fast-responding catchments during the period 2021-2060, whereas catchments with dampened hydrographs show a mixture of greater or smaller return periods (Steele-Dunne et al., 2008). Kay and Jones (2012) suggest significantly increasing flood discharges in most parts of the UK while Scotland showed decreasing tendencies.

Lehner et al. (2006) and Rojas et al. (2011) anticipate increasing floods in northern and northeastern Europe, Arheimer et al. (2012) project very little change overall in water discharge for the region, while Dankers and Feyen (2009) and Hirabayashi et al. (2008) project lower return periods. In southeastern Norway, the annual mean flood is projected to decrease by about $5 \%$ due to lower snow accumulation in winter (Erichsen and Sælthun, 1995). If no seasonal change occurs (i.e. no shift from spring flood to an autumn flood regime), there is no projected increase in the return period of extreme floods.

For Sweden, overall, a decreasing trend in spring flood peaks has been projected (Andréasson et al., 2004) together with an increase in rain-fed autumn/winter floods (Arheimer and Lindström, 2014). Similar findings are obtained for the 100-year floods where median projections showed no changes in the northern part of Sweden, but downward trends in the centre, mainly resulting from decreasing snowmelt floods in spring, while rain-fed floods in the south showed the opposite tendency. However, the spread in the ensemble of flood projections (25-75 percentiles) ranged between $\pm 50 \%$ (Bergström et al., 2012). The 100-year floods in the snowmelt-dominated regions in Finland are projected to decrease or remain unchanged (Veijalainen et al., 2010); in Denmark, they are projected to increase modestly (Thodsen, 2007).

\section{(ii) Central Europe and eastern Europe}

In central Europe mixed changes in flood regimes and return periods have been projected depending on the river and river reach (Dankers and Feyen, 2009; Rojas et al., 2012). For the Meuse River (France, Belgium and the Netherlands), decreasing 100-year floods are projected (Leander et al., 2008). In Germany, the changes depend on the seasonal climate. Overall, the $Q_{5}$ flows in northwestern Germany (winter floods) may increase due to increasing precipitation in winter, while in the snowmelt-dominated rivers of the south with summer floods the pattern is more complex (Bosshard et al., 2013; Huang et al., 2013).

For the Alpine region, projected changes are also complex. Kundzewicz et al. (2010) reviewed two studies, with one showing decreasing return periods of the 100-year flood and the other showing a mixed change (decreasing and increasing), whereas an increase has been projected by Rojas et al. (2011). If-then scenarios in Austria analysed different flood change mechanisms, suggesting higher flood discharges in the northeast and small changes in the rest of the country (Blöschl et al., 2011). The mean annual floods in Switzerland are projected to increase in most parts of the country for the periods 2025-2046 and 2074-2095 with a stronger change signal in the latter period, but to decrease in the southern Alpine catchments (Köplin et al., 2014). An intercomparison of results for the Alpine Rhine - using different climate models, downscaling procedures, and hydrological models - has shown that all these factors significantly contribute to the total uncertainty (Bosshard et al., 2014).

A mixed pattern of increasing and decreasing flood frequencies across eastern Europe is projected depending on the river system analysed. For the eastern reaches of the Danube River a strong increase in the 100-year flood has been projected (Dankers and Feyen, 2009; Rojas et al., 2012), but a 
decrease has been projected in the Baltic region (Dankers and Feyen, 2009; Rojas et al., 2011, 2012).

\section{(iii) Mediterranean}

In the Mediterranean, the 100-year flood is projected to mainly increase (Rojas et al., 2012), particularly in the eastern Mediterranean, with a less clear signal in the Mediterranean (Rojas et al., 2011). For Mediterranean France, Dumas et al. (2013) projected increased 100-year floods, particularly for the lower Rhone Basin, similarly for the eastern reaches of the Po River (Dankers and Feyen, 2009; Rojas et al., 2012). For the Upper Soĉa River in Slovenia, increasing high-flow magnitudes have been projected as well (Janža, 2011).

Overall, the patterns of the flood change projections over Europe are not very clear. There may be important local effects that are masked at the European scale. In addition, there are differences in the methods and assumptions. A more coherent analysis would be desirable.

\subsection{Flood change projections in Europe - challenges and opportunities}

Similar to the change detection methods of Sect. 2.3, there are challenges and opportunities for the scenario approach. They have been organised into hydrological model uncertainty (Sect. 3.3.1), ensemble spread (Sect. 3.3.2) and feedbacks (Sect. 3.3.3).

\subsubsection{Hydrological modelling uncertainty}

An important feature of flood projections derived from the scenario approach is that they cannot be validated against observed data because of the long lead times of decades. This is different from short-term forecasting where today's flood forecasts can be checked on the following day (Nester et al., 2012a, b). The uncertainties involved in the scenario approach, therefore, need to be carefully assessed.

One of the main assumptions in scenario modelling is that the model structure and the model parameters equally apply to the present and the future conditions (Klöcking and Haberlandt, 2002; Merz and Blöschl, 2009; Blöschl and Montanari, 2010). This may not always be a good assumption and may be difficult to check due to issues with controlled experiments, short record lengths, the high natural variability and scale problems (DeFries and Eshleman, 2004; Blöschl and Sivapalan, 1995). Consequently, relationships between model parameters and relevant land use characteristics may not be identifiable except in small experimental catchments (Kostka and Holko, 2006; O'Connell et al., 2007; McIntyre and Marshall, 2010; Ewen et al., 2013; McIntyre et al., 2014; Pattison and Lane, 2012).

Similar concerns apply to changed climate conditions as hypotheses need to be introduced in relation to how the hy- drological system will respond to changes (e.g. Hundecha and Bárdossy, 2004; Bulygina et al., 2009; Brigode et al., 2013). Merz et al. (2011) note that very substantial biases might be introduced into the model parameters when calibrating them against trending hydrological records in a changing climate. Also, rainfall input and its correspondence with other variables (such as air temperature and vegetation dynamics) may be uncertain, particularly when moving to extremes (Seneviratne et al., 2012).

These uncertainties can be explicitly considered in various ways in the scenario approach. One option is to propagate the uncertainty of the inputs through the model, combining it with the uncertainty in the model parameters and the model structure (Montanari et al., 2009). Montanari and Koutsoyiannis (2012) propose an operator-based framework for estimating the associated distributions based on data and expert judgement. While the approach is appealing, as the probabilities are made transparent, assumptions need to be made regarding how to estimate and combine them.

An alternative to the uncertainty propagation method is to analyse spatial gradients, as it is already widely done in ecology (e.g. Ter Braak and Prentice, 1988) and increasingly in hydrology (Wagener et al., 2010; Peel and Blöschl, 2011). The idea of this approach is that, under changed land use or climate conditions, hydrological processes in a catchment may become similar to those experienced in other catchments under current land use or climate conditions. However, as Peel and Blöschl (2011) note, using spatial gradients has limitations, as other relevant catchment characteristics may not be similar.

While there is no one-fits-all approach to accounting for uncertainties, it is very important to estimate and communicate the uncertainties involved in the scenario approach. In particular, the "signal to noise ratio" is an important characteristic that is useful to ascertain and to communicate whether the simulated impact is significantly larger than the uncertainties of the model. Also, in the spirit of the original idea of the scenario approach (as opposed to forecasts) (Van Der Heijden, 1996), it would be useful to frame the problems in such a way that the scenarios differ by the main uncertainties rather than trying to accommodate all the uncertainties into a single scenario, as they then become de facto forecast.

\subsubsection{Ensemble spread in climate variables}

Climate models involve a range of uncertainties (e.g. Viner, 2003; Stainforth et al., 2007; Hawkins and Sutton, 2009) and large biases can be found for some RCM-GCMs, so caution needs to be exercised when downscaling and applying projections (Turco et al., 2013).

Among others, the uncertainties stem from:

- Limited predictability of internal variations: the climate system is highly nonlinear with interactions over a wide range of temporal and spatial scales, which render some 
of the internal variations intrinsically difficult to predict (e.g. Palmer, 2000; Nicolis et al., 2009).

- Model imperfections: due to incomplete knowledge of the underlying dynamics, insufficient computational resolution and imperfect model parameterisation schemes that leave out important sub-grid processes (e.g. Murphy et al., 2007), climate models tend to show substantial errors (in terms of means and variations) in particular at small space-time scales.

- Scenario uncertainties: scenarios of greenhouse gas and aerosol emissions make implicit assumptions about demographic and societal developments, which may limit the accuracy of projections (see Sect. 3.1).

- Role of extremes: as extremes are per definition rare, it is difficult to validate them in the models, and implies sampling uncertainties when estimating trends or changes from model output.

Yet, understanding all of these uncertainties is essential for assessing flood regime projections in a realistic way.

To account for these uncertainties and biases, the likelihood of a model run is normally assessed from the difference between simulations and observed data. However, in the case of climate projections, there are no future observations available; therefore differences between many simulations of different GCMs (ensembles) are generally used to obtain an uncertainty measure (Blöschl and Montanari, 2010; Bosshard et al., 2013). However, such an approach only accounts for a limited range of possible futures, which may underestimate the real spread or uncertainty of the projections. For a complete uncertainty estimation, all possible futures, including those outside the space covered by the GCMs, should be accounted for. As Taleb (2007, p. 51) noted, it is important not to confound "no evidence of possibility" with "evidence of no possibility".

Bayesian methodologies represent one option for framing the uncertainty of climate scenarios. The Bayesian assessment can be conducted directly on the climate variables (e.g. Fischer et al., 2012) or at the end of the uncertainty chain on the floods themselves. Another option, already used in weather forecasting, consists of dynamically pre-processing the ensemble of initial conditions with data assimilation schemes (e.g. Pires et al., 1996; Rawlins et al., 2007). The purpose of the procedure is to obtain a new distribution of inputs that, once fed into the dynamical model in forecast mode, can maximise the spread of the output.

Another approach is a group of concepts referred to as the "scenario-neutral" framework (Prudhomme et al., 2010), the vulnerability approach or the bottom-up approach (Wilby and Dessai, 2010; Blöschl et al., 2013d). The scenarioneutral framework involves sampling changes in future climate variables that include but are not limited to the range of GCM projections. The idea is to broaden the spectrum of possible futures and identify sensitivity thresholds in the catchment response to changed climate inputs. In a similar fashion, the vulnerability and bottom-up approaches start at the local scale of households and communities to explore what conditions enable successful coping with floods (Wilby and Dessai, 2010). The focus is on the vulnerability and resilience of the risk-related system itself rather than on climate projections (Hall and Murphy, 2011; van Pelt and Swart, 2011) with the aim to develop robust and flexible strategies for dealing with changing floods.

\subsubsection{Feedbacks}

Catchments tend to respond to changes in land use and climate in a nonlinear way involving a multitude of interlinked processes. Feedback processes involved in the co-evolution of soils, vegetation, climate and landscapes may result in complex patterns of flood response (Gaál et al., 2012). Heavier rainfall may increase erosion over the hill slopes, which in turn may cause landslides and enhanced flooding. Vegetation may respond to changes in precipitation and air temperature over months or years by changed rooting depths and stomata conductance while over longer time scales, genetic adaptation, and migration of species may occur. Changing the vegetation type (e.g. by deforestation) may invoke a complex causal chain of process changes and bistable dynamic behaviour (Runyan et al., 2012) affecting flooding via interception, evapotranspiration and infiltration changes. Feedbacks between soil moisture and precipitation occur from local to global scales and may have very significant effects on the magnitude of precipitation (Hohenegger et al., 2009; Van der Ent and Savenije, 2011).

Similarly, feedbacks exist between human actions and flood changes, such as the levee effect where people tend to move into the flood risk area when levees are built as they feel protected (White, 1945; Di Baldassarre et al., 2013a), thereby increasing their flood risk. However, the intricacy of the interactions and feedbacks between societies and floods and vice versa are still to be understood (Merz et al., 2014).

One way of shedding light on the feedbacks is the use of comparative studies (Falkenmark and Chapman, 1989; Blöschl et al., 2013d). The idea is to learn from the similarities and differences between different catchments. Gaál et al. (2012), for example, explored the role of landscape coevolution processes in flood event response by contrasting catchments with different climates and landforms. The comparative approach can be combined with the traditional scenario approach to help to identify general patterns in spite of the particularities of individual catchments. As concluded by Robinson et al. (2003) a relative consistency of results between regions gives confidence in the generality of the findings.

If the feedbacks can be specified it is possible to model them with complex process models of the system. An example is modelling the response of natural vegetation to 
changed climatic conditions (e.g. Bonan et al., 2003; Gerten et al., 2004; Gray and Hamann, 2012; Hanewinkel et al., 2012), although the models are sometimes not fully coupled. Another example are land-surface-atmosphere precipitation feedbacks that are relevant to flooding (Hohenegger et al., 2009), as floods are driven by both event precipitation and antecedent soil moisture, so feedbacks will have a major effect on flood magnitudes. Afforestation can also not only change the runoff properties of the catchment, but also the stream morphology. Reduction of sediment erosion at the scale of the basin does influence the bed-load sediment within the rivers (Kondolf et al., 2002; Piégay et al., 2004). In contrast, the increasing of temperature is expected to induce a general melting of glaciers. That will increase the extent of mountainous areas with a large amount of available sediment for bank erosion.

An alternative consists of low-dimensional models where the focus is on the main features of the coupled dynamics rather than on the process details. For the cases of water-plant feedbacks, these models are playing an important role in eco-hydrology (e.g. Eagleson, 1982); for the case of water-people feedbacks, these models are playing an important role in socio-hydrology (e.g. Sivapalan et al., 2012; Montanari et al., 2013). For example, Di Baldassarre et al. (2013b) developed four coupled nonlinear differential equations to represent the evolution of a settlement in a floodplain with the options of building flood protection measures and/or moving away from the stream. The model was able to simulate observed macro-scale interaction patterns, such as the levee effect. The model was also used to show that the development of the community in the floodplain might be dependent on the sequence of the flood occurrence rather than on the probabilities of the flood magnitudes alone (Viglione et al., 2014) and that bistable dynamic behaviour may occur for some parameter combinations. While these models are investigative rather than predictive, they are an appealing opportunity for better exploring the flood evolution patterns resulting from the coupled process dynamics in order to complement existing scenario runs and case studies of past flood changes.

\section{Towards better understanding flood changes}

\subsection{A synthesis of approaches}

Sections 2 and 3 have reviewed change detection and scenario approaches respectively that are used to analyse flood regime changes. Each of the approaches has strengths and limitations. Change detection methods are strongly data based, and therefore represent real variability to a large degree, but they do not necessarily easily infer the causality of flood changes. Conversely, scenario methods are strongly model based, so causality is included, but sometimes it is not clear how well reality is actually represented.
The two methods are complementary, so there may be value in combining their respective strengths. On one hand, there is scope for learning about flood change causality in the context of change detection methods. On the other hand, there is scope for improving the realism of scenarios to better match real flood regime dynamics. These opportunities are schematically visualised in Fig. 11 and each of the opportunities is discussed below in a separate section.

\subsubsection{Going beyond trend analysis of floods}

The traditional change detection methods give some insight into flood regime changes but the results strongly depend on the observational window and the assumption about the nature of the change (e.g. monotonic trends, step changes). It is therefore important to go beyond the traditional trend detection and analyse other forms of change such as fluctuations and other nonlinear variations in hydrological series. Recently, new methods have been developed that are better suited for detecting nonlinearities in time series. For example, the information-theoretical measures of Pires and Perdigão (2007) and Brunsell (2010) can be used to identify spatio-temporal patterns. The empirical mode decomposition and maximum entropy spectral methods of Sang et al. (2012) can be used to identify complex periodicity in the time series. These methods may also give additional impetus for identifying flood-rich and flood-poor periods in the records rather than trend methods alone.

As long duration records offer better insights into nonlinearities and fluctuations compared to short records, there is potential in combining systematic flood records with historic flood data from a diverse set of sources. To obtain a truly continental-scale overview, systematic research in multiple catchments is required where good documentary sources are available (to create long flood time series) coupled with the broad co-operation of researchers from various countries. The ability to reconstruct peak discharges for past floods, based on epigraphic and other documentary sources, represents an important development in incorporating historical information into flood change analyses (e.g. Herget and Meurs, 2010; Elleder et al., 2013).

\subsubsection{Attributing causes to observed flood changes}

The detection of changes in flood time series is a good starting point, but for predicting future changes in the flood regimes, it is even more important to understand the underlying mechanisms. For this purpose, the synergies with the model-based (scenario) approach should be exploited more thoroughly. A number of options exist. For example, Renard et al. (2008) detected flood changes over distinct time periods in northeast France using the method of Andréassian et al. (2003). They calibrated a hydrological model to separate periods and then tested each period for trends. This approach 


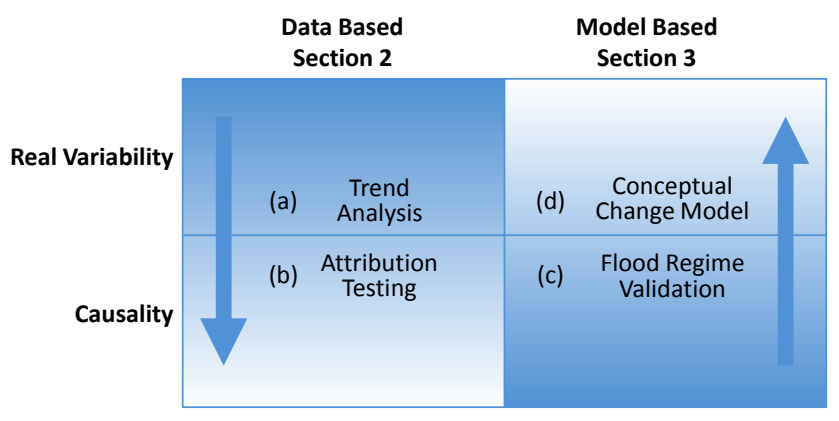

Figure 11. Synthesis of approaches to analysing flood regime changes. Dark blue shading indicates the current strengths of the data-based (change detection) and model-based (scenario) approaches, light blue shading indicates future opportunities for these methods with regard to their current ability to represent causalities and variabilities. The proposed synthesis items (a)-(d) correspond to Sects. 4.1.1-4.1.4.

allowed them to attribute the flood peak to an increasing number of rainy days in most of the investigated catchments.

However, the possibility of multiple interacting drivers of change further complicates the attribution process (Harrigan et al., 2014). Merz et al. (2012) therefore suggested approaching the attribution problem systematically by postulating a hypothesis and successively testing it against observed data and/or simulation results.

They propose tests at three stages:

1. Evidence of consistency: show that the changes in floods detected in the data are consistent with the hypothesised drivers.

2. Evidence of inconsistency: show that the observed flood changes are inconsistent with alternative drivers.

3. Confidence level: provide a statement on the confidence of the attribution hypothesis.

The proof of inconsistency with alternative drivers is probably the most difficult part of the test, which is further complicated by the need for detailed metadata information (Harrigan et al., 2014). More research following the framework suggested by Merz et al. (2012) would be useful in advancing the understanding of the drivers in flood regime changes.

\subsubsection{Validating scenarios against observed flood regime dynamics}

A synthesis of approaches may also help strengthening the model-based (scenario) approach by drawing upon what can be learned from past flood regime changes. Traditionally, knowledge about the past enters into the model chain in implicit ways through calibration against observed data. Flood scenarios can be used to enhance process understanding by analysing the variability ranges of past extreme flood events (Helms et al., 2012).
The flood regime history over long time periods can be used more explicitly to test models, which will increase their ability to attribute observed changes and predict future changes. For example, Hundecha and Merz (2012) calibrated a weather generator and a hydrological model for eight catchments and tested the outcomes of the model chain against observed floods in a more comprehensive way than is usually done in the scenario approach. They generated different scenarios of past climates to assess systematically the relative importance of different climate variables in explaining the detected flood changes. This approach tests the hypothesis that observed flood changes are climate driven (proof of consistency). Other opportunities for exploiting the synergies of the two types of methods include the use of macroscale information, such as the observed seasonality of floods, to strengthen modelling approaches and to improve flood regime predictions.

\subsubsection{Low-dimensional change models for flood changes}

An alternative to the traditional scenario approach is to link the attribution of past changes and future projections directly through causalities. Delgado et al. $(2010,2012,2014)$ explore this avenue for the Lower Mekong River. They found that average floods have slightly decreased during the last few decades, but that the variability of the annual maximum floods has increased significantly. Using wind velocities as proxies for monsoon activity, they identified the variance of the western North Pacific monsoon intensity as a main driver of changes in flood variance, which they used to model nonstationary flood probabilities as a function of monsoon intensity. This approach opens the possibility to estimate future flood regime changes directly from GCMs, which is appealing as monsoon intensity is based on average wind velocities over large areas, which are reasonably well simulated by GCMs, bypassing the use of precipitation usually poorly simulated by climate models. A similar idea of combining attribution and projection was proposed by Kwon et al. (2008) who used a Bayesian hierarchical model to estimate flood probabilities in Montana from sea surface temperature indices, snowpack depth and GCM season-ahead forecasts of precipitation.

The approaches presented above offer the possibility for establishing direct causality links for observed and projected European flood changes. Low-dimensional models have also the potential of representing feedbacks of driverimpact linkages in the spirit of socio-hydrology models (e.g. Di Baldassarre et al., 2013b) and are appealing to complement the traditional scenario approach. 


\subsection{A call for joint flood change research at the European scale}

\subsubsection{Need for a European-wide effort}

In order to understand better flood regime changes in Europe, a regional perspective of floods and their drivers is needed. A European collaborative effort may target both the regional differences in flood drivers across Europe and the patterns of change that span across national boundaries as shown above. Pan-European collaboration brings benefits for both broader scientific assessments and efficiency gains by targeted exchange of methods and results.

Identifying hydrological patterns beyond the catchment or national scales will help with attributing changes in hydrological regimes influenced by large-scale processes such as climate change (Whitfield et al., 2012). By comparing and contrasting observed and projected flood regime changes in a comparative way across European sub-regions, new insights in deciphering flood-generating processes, controls and changes can be gained. Also, as the European Flood Directive (EU, 2007) is putting more emphasis on harmonising flood risk management measures across river basins (Quevauviller, 2011; Quevauviller et al., 2012), a European-wide research effort is becoming increasingly important.

Another important role of a European-wide effort is to organise and share data relevant to understanding flood regime changes across Europe. There are a number of European projects that have compiled and made available flood data across Europe such as the HYDRATE (Hydrometeorological Data Resources and Technology for Effective Flash Flood Forecasting) project (Gaume et al., 2009; Borga et al., 2011) and the COST Action on European procedures for flood frequency estimation (Kjeldsen, 2011; Salinas et al., 2013). However, a number of barriers may hinder collaboration at a European scale. The survey of Viglione et al. (2010b) conducted in 32 European countries suggests that these barriers may include restrictions imposed by hydrometric authorities, legal constraints and economic reasons due to the costs of the data, conflicting interests between data providers and data end-users, and the awareness and apprehension of data misuse. Understanding such barriers is a first step towards enhancing the data exchange. The INSPIRE Directive on free exchange of environmental spatial information will likely contribute to a more coherent access to European data relevant to flood changes. Nevertheless, more informal and interdisciplinary collaborations across Europe are needed.

\subsubsection{Building blocks of a European flood change research network}

To foster a joint European effort on flood research, a platform is needed that facilitates collaboration across trans-boundary catchments and national boundaries. An informal and open "Flood Research Consortium" has been proposed recently to extend the COST initiative on flood frequency estimation, within the ERC Advanced grant "FloodChange - Deciphering river flood change". The purpose of the consortium is to foster joint cross-border research on understanding flood processes and associated changes at the European scale. It is suggested that a number of building blocks are needed for such a consortium to work in a sustainable way, which can be summarised as follows.

\section{(i) Common framework}

One of the essential features of merging information and research across countries is a common scientific framework. There should be a common understanding of what research questions to address, even though a diversity of approaches may exist, which in fact, may make it possible to obtain more robust research results.

\section{(ii) Common protocol}

A common protocol on how to proceed in hypothesis testing (Laio et al., 2009) would enhance the coherence of the research of the consortium. Equally important is a common protocol on presenting and sharing data (Hannah et al., 2011) and on reporting scientific results in the hydrological literature (Parajka et al., 2013).

\section{(iii) Common commitment}

A common commitment across such a consortium is needed to ensure coherent research approaches, data quality and sufficient access to metadata, with every member willing to participate. This is why regional and national research by individuals and their local knowledge will still play an important role. However, by collaborative research a broader picture of flood research can emerge.

\section{(iv) Incentives}

A consortium member will benefit through joint research based on exchange of data, models, expertise and staff. By working and publishing together on a common study object, i.e. European floods, the opportunity to go beyond one's own spatial region of expertise may provide motivation along with an increase in scientific visibility and credibility.

Examples of powerful informal networks are the Decades of the International Association of Hydrological Sciences (IAHS). The Predictions in Ungauged Basins (PUB) Decade has been instrumental in synthesising hydrological research that had been fragmented before (Blöschl et al., 2013c; Hrachowitz et al., 2013), and a similar decade is under way on hydrological change and its connection to society, entitled "Panta Rhei - Everything Flows" (Montanari et al., 2013). Such informal networks can form the basis of more formal networks in which international collaborations are established to work together in a planned manner. Both kinds 
of networks will be important stepping-stones towards better understanding the processes of flood regime changes in Europe.

\section{Recommendations}

Based on the review in this paper, the following recommendations that exploit the synergies between the change detection and scenario approaches are offered:

- Combining systematic flood data with documentary flood data from diverse sources is recommended as an opportunity to gain insight into long-term flood regime dynamics.

- Change analyses of flood data should focus on identifying flood-rich and flood-poor periods instead of just detecting whether trends exist. The process reasons of flood-rich and flood-poor periods (e.g. Hurst phenomenon) should be explored. Nonlinear statistical methods offer potential for detecting patterns of flood regime dynamics.

- Attribution methods for observed flood changes should be developed that involve process models, such as those used in scenario analyses and are based on formal hypothesis testing, ideally in a regional context.

- Models used for to derive scenarios should be validated more thoroughly against observed long flood data series, including process indicators such as flood seasonality.

- Scenario analyses should be framed such that the scenarios differ by the main uncertainties rather than trying to accommodate all the uncertainties into a single scenario. For each scenario, the ensemble spread needs to cover the full uncertainty range. Uncertainties need to be communicated in a suitable way.

- Low-dimensional change models should be developed that directly link macro-scale mechanisms of change to flood magnitudes and account for the main feedbacks.

- An informal European flood change research network should be established to explore the large-scale patterns of flood regime changes and to learn from the similarities and differences of flood processes within Europe using comparative approaches.

Acknowledgements. We would like to acknowledge the support of the ERC Advanced Grant "FloodChange", project no. 291 152, the Austrian Academy of Sciences (ÖAW) Project "Mountain Floods" and the COST action European procedures for flood frequency estimation, grant ES0901. In addition, we would like acknowledge financial support from the Austrian Science Funds
FWF as part of the Doctoral Programme on Water Resource Systems (DK-plus W1219-N22). We would also like to thank the participants of the September 2012 ERC symposium in Vienna. The building blocks appointed for community building are defined and elaborated upon in the recently started EU FP7 Collaborative project "SWITCH-ON" under the Environment programme, grant no. 603 587. The present work was partially developed within the framework of the "Panta Rhei" Research Initiative of the International Association of Hydrological Sciences (IAHS). The authors also wish to thank L. Elleder for providing the Vltava data used in Fig. 8. The contribution of J. Szolgay to this paper has been partly supported by the Slovak Research and Development Agency, contract no. APVV 0496-10 and the contribution of R. Brázdil by the project of the Grant Agency of the Czech Republic no. P209/11/0956.

Edited by: G. Di Baldassarre

\section{References}

Abarbanel, H. D. I.: Analysis of Observed Chaotic Data, Springer, New York, 272 pp., 1996.

Ahmad, S. and Simonovic, S. P.: System dynamics modeling of reservoir operations for flood management, J. Comput. Civil. Eng., 14, 190-198, 2000.

Alcrudo, F.: A state of the art review on mathematical modelling of flood propagation, First IMPACT project Workshop, Wallingford, UK, available at: http://www.impact-project.net/cd/papers/ print/008_pr_02-05-16_IMPACT_Alcrudo.pdf (last access: December 2013), 2002.

Allamano, P., Claps, P., and Laio, F.: Global warming increases flood risk in mountainous areas, Geophys. Res. Lett., 36, L24404, doi:10.1029/2009GL041395, 2009.

Amponsah, W., Borga, M., Marchi, L., Boni, G., Cavalli, M., Comiti, F., Crema, S., Ana, L., Marra, F., and Zoccatelli, D.: The flash flood of October 2011 in the Magra River basin (Italy): rainstorm characterisation and flood response analysis, J. Hydrometeorol., in review, 2014.

Andréassian, V.: Waters and forests: from historical controversy to scientific debate, J. Hydrol., 291, 1-27, doi:10.1016/j.jhydrol.2003.12.015, 2004.

Andréassian, V., Parent, E., and Michel, C.: A distribution-free test to detect gradual changes in watershed behavior, Water Resour. Res., 39, 1252, doi:10.1029/2003WR002081, 2003.

Andréasson, J., Bergström, S., Carlsson, B., Graham, L. P., and Lindström, G.: Hydrological change-climate change impact simulations for Sweden, Ambio, 33, 228-234, doi:10.1579/00447447-33.4.228, 2004.

Apel, H., Thieken, A. H., Merz, B., and Blöschl, G.: Flood risk assessment and associated uncertainty, Nat. Hazards Earth Syst. Sci., 4, 295-308, doi:10.5194/nhess-4-295-2004, 2004.

Apel, H., Thieken, A. H., Merz, B., and Blöschl, G.: A probabilistic modelling system for assessing flood risks, Nat. Hazards, 38, 79 100, doi:10.1007/s11069-005-8603-7, 2006.

Arheimer, B. and Lindström, G.: Climate impact on floods changes of high-flows in Sweden for the past and future (1911-2100), Hydrol. Earth Syst. Sci. Discuss., 11, 7551-7584, doi:10.5194/hessd-11-7551-2014, 2014. 
Arheimer, B. and Wittgren, H. B.: Modelling nitrogen removal in potential wetlands at the catchment scale, Ecol. Eng., 19, 63-80, doi:10.1016/S0925-8574(02)00034-4, 2002.

Arheimer, B., Dahné, J., Lindström, G., Marklund, L., and Strömqvist, J.: Multi-variable evaluation of an integrated model system covering Sweden (S-HYPE), IAHS Publ., 345, 145-150, 2011.

Arheimer, B., Dahné, J., and Donnelly, C.: Climate change impact on riverine nutrient load and land-based remedial measures of the Baltic Sea Action Plan, Ambio, 41, 600-612, doi:10.1007/s13280-012-0323-0, 2012.

Bača, P. and Bačová Mitková, V.: Analysis of seasonal extreme flows using peaks over threshold method, J. Hydrol. Hydromech., 55, 16-22, 2007.

Bacová-Mitková, V. and Halmová, D.: Joint modeling of flood peak discharges, volumes and duration: A case study of the Danube River in Bratislava, J. Hydrol. Hydromech, 62, 1-11, doi:10.2478/johh-2014-0026, 2014.

Bard, A., Renard, B., and Lang, M.: Floods in the Alpine areas of Europe, in: Changes in Flood Risk in Europe, edited by: Kundzewicz, Z. W., IAHS Press, Wallingford, UK, 362-371, 2012.

Bárdossy, A., Stehlik, J., and Bálint, G.: Investigation of the flood producing weather situations of the $20^{\text {th }}$ century for the upper part of the Tisza basin, in: Palaeofloods, Historical Data and Climatic Variability: Applications in Flood Risk Assessment, Proceedings of the PHEFRA International Workshop, October 2002, edited by: Thorndycraft, V. R., Benito, G., Barriendos, M., and Llasat, M. C., CISC, Barcelona, 301-306, 2002.

Bárdossy, A., Kontur, I., Stehlik, J., and Bálint, G.: Could the global warming cause the last floods of the Tisza River?, in: Water Resources Systems - Hydrological Risk, Management and Development, Proceedings of Symposium HS02b held during IUGG2003, July 2003, IAHS Publ. No. 281, edited by: Blöschl, G., Sapporo, 2003.

Barnolas, M. and Llasat, M. C.: Metodología para el estudio de inundaciones históricas en España e implementación de un SIG en las cuencas de Ter, Segre y Llobregat, Centro de Estudios y Experimentación de Obras Públicas, Monograffas CEDEX, 90, 264 pp., 2007a.

Barnolas, M. and Llasat, M. C.: A flood geodatabase and its climatological applications: the case of Catalonia for the last century, Nat. Hazards Earth Syst. Sci., 7, 271-281, doi:10.5194/nhess-7271-2007, 2007b.

Barredo, J. I.: Normalised flood losses in Europe: 1970-2006, Nat. Hazards Earth Syst. Sci., 9, 97-104, doi:10.5194/nhess-9-972009, 2009.

Barriendos, M., Coeur, D., Lang, M., Llasat, M. C., Naulet, R., Lemaitre, F., and Barrera, A.: Stationarity analysis of historical flood series in France and Spain (14th-20th centuries), Nat. Hazards Earth Syst. Sci., 3, 583-592, doi:10.5194/nhess-3-5832003, 2003.

Bayliss, A. C. and Jones, R. C.: Peaks-over-threshold flood database: Summary statistics and seasonality, IH Report No. 121, Institute of Hydrology, Wallingford, UK, 1993.

Benestad, R. E. and Haugen, J. E.: On complex extremes: flood hazards and combined high springtime precipitation and temperatures in Norway, Climatic Change, 85, 381-406, doi:10.1007/s10584-007-9263-2, 2007.
Benito, G., Diéz-Herrero, A., and Fernández de Villalta, M.: Magnitude and frequency of flooding in the Tagus basin (Central Spain) over the last millennium, doi:10.1023/A:1023417102053, Climatic Change, 58, 171-192, 2003.

Benjamini, Y. and Hochberg, Y.: Controlling the false discovery rate - a practical and powerful approach to multiple testing, J. Roy. Stat. Soc. B, 57, 289-300, 1995.

Bergström, S., Andréasson, J., and Graham, L. P.: Climate adaptation of the Swedish guidelines for design floods for dams, in: Proceedings of the 24th ICOLD Congress on Large Dams June 2012, Q.94-R.2, Kyoto, Japan, 11-27, 2012.

Beurton, S. and Thieken, A.: Seasonality of floods in Germany, Hydrolog. Sci. J., 54, 62-76, doi:10.1623/hysj.54.1.62, 2009.

Bíba, M., Oceánská, Z., Vícha, Z., and Jařabáč, M.: Foresthydrological research in small experimental catchments in the Beskydy mountains, J. Hydrol. Hydromech., 54, 113-122, 2006.

Birsan, M.-V., Molnar, P., Burlando, P., and Pfaundler, M.: Streamflow trends in Switzerland, J. Hydrol., 314, 312-329, doi:10.1016/j.jhydrol.2005.06.008, 2005.

Birsan, M.-V., Zaharia, L., Chendes, V., and Branescu, E.: Seasonal trends in Romanian streamflow, Hydrol. Process., 28, 44964505, doi:10.1002/hyp.9961, 2014.

Black, A. R. and Werritty, A.: Seasonality of flooding: a case study of North Britain, J. Hydrol., 195, 1-25, doi:10.1016/S00221694(96)03264-7, 1997.

Blöschl, G.: Statistical upscaling and downscaling in hydrology, in: Encyclopaedia of Hydrological Sciences, J. Wiley \& Sons, Chichester, 135-154, 2005.

Blöschl, G. and Montanari, A.: Climate change impacts - throwing the dice?, Hydrol. Process., 24, 374-381, doi:10.1002/hyp.7574, 2010.

Blöschl, G. and Sivapalan, M.: Scale issues in hydrological modelling: a review, Hydrol. Process., 9, 251-290, doi:10.1002/hyp.3360090305, 1995.

Blöschl, G., Ardoin-Bardin, S., Bonell, M., Dorninger, M., Goodrich, D., Gutknecht, D., Matamoros, D., Merz, B., Shand, P., and Szolgay, J.: At what scales do climate variability and land cover change impact on flooding and low flows?, Hydrol. Process., 21, 1241-1247, doi:10.1002/hyp.6669, 2007.

Blöschl, G., Reszler, C., and Komma, J.: A spatially distributed flash flood forecasting model, Environ. Model. Softw., 23, 464-478, doi:10.1016/j.envsoft.2007.06.010, 2008.

Blöschl, G., Viglione, A., Merz, R., Parajka, J., Salinas, J., and Schöner, W.: Climate impacts on floods and low flows, Auswirkungen des Klimawandels auf Hochwasser und Niederwasser, Österreichische Wasser- und Abfallwirtschaft, 63, 21-30, 2011.

Blöschl, G., Merz, R., Parajka, J., Salinas, J., and Viglione, A. Floods in Austria, in: Changes in Flood Risk in Europe, edited by: Kundzewicz, Z. W., IAHS Press, Wallingford, 169-177, 2012.

Blöschl, G., Nester, T., Komma, J., Parajka, J., and Perdigão, R. A. P.: The June 2013 flood in the Upper Danube Basin, and comparisons with the 2002, 1954 and 1899 floods, Hydrol. Earth Syst. Sci., 17, 5197-5212, doi:10.5194/hess-17-51972013, 2013a.

Blöschl, G., Nester, T., Komma, J., Parajka, J., and Perdigão, R. A. P.: Das Juni-Hochwasser 2013 - Analyse und Konsequenzen für das Hochwasserrisikomanagement (The June 2013 flood 
- analysis and implications for flood risk management), Journal of Austrian Architects and Engineers, Österreichische Ingenieurund Architekten-Zeitschrift, 158, 141-152, 2013b.

Blöschl, G., Sivapalan, M., Wagener, T., Viglione, A., and Savenije, H. (Eds.): Runoff Prediction in Ungauged Basins: Synthesis Across Processes, Places and Scales, Cambridge University Press, UK, 465 pp., 2013c.

Blöschl, G., Viglione, A., and Montanari, A.: Emerging approaches to hydrological risk management in a changing world, in: Climate Vulnerability: Understanding and Addressing Threats to Essential Resources, Elsevier Inc., Academic Press, Oxford, 310, doi:10.1016/B978-0-12-384703-4.00505-0, $2013 \mathrm{~d}$.

Bogdanov, V. I. and Malova, T. I.: Reconstructing Heights of Historical Neva Floods, 1721-1777, Dokl. Earth Sci., MAIK Nauka/Interperiodica, 443, 353-356, 2012.

Bonan, G. B., Levis, S., Stephen, S., Vertenstein, M., and Oleson, K. W.: A dynamic global vegetation model for use with climate models: concepts and description of simulated vegetation dynamics, Global Change Biol., 9, 1543-1566, doi:10.1046/j.13652486.2003.00681.x, 2003.

Borga, M., Anagnostou, E., Blöschl, G., and Creutin, J. D.: Flash flood forecasting, warning and risk management: the HYDRATE project, Environ. Sci. Policy, 14, 834-844, doi:10.1016/j.envsci.2011.05.017, 2011.

Borisenkov, Ye. P.: Documentary evidence from the U.S.S.R., in: Climate Since A.D. 1500, edited by: Bradley, R. S. and Jones, P., Routledge, London, 171-183, 1995.

Borisenkov, Ye. P. and Pasetsky, V. M.: Extreme Natural Phenomena in Russian Chronicles of the 11th to the 17th Centuries, Gidrometeoizdat, Leningrad, 1983.

Borisenkov, Ye. P. and Pasetsky, V. M.: Millennium-Long Chronicle of Unusual Natural Events, Misl', Moscow, 1988.

Borisenkov, Ye. P. and Pasetsky, V. M.: Chronicle of Unusual Natural Events During the Last 2.5 Millennia, Gidrometeoizdat, St. Petersburg, 2003.

Bosshard, T., Kotlarski, S., Ewen, T., and Schär, C.: Spectral representation of the annual cycle in the climate change signal, Hydrol. Earth Syst. Sci., 15, 2777-2788, doi:10.5194/hess-15-27772011, 2011.

Bosshard, T., Carambia, M., Görgen, K., Kotlarski, S., Krahe, P., Zappa, M., and Schär, C.: Quantifying uncertainty sources in an ensemble of hydrological climate-impact projections, Water Resour. Res., 49, 1-14, doi:10.1029/2011WR011533, 2013.

Bosshard, T., Kotlarksi, S., Zappa, M., and Schär, C.: Hydrological climate-impact projections for the Rhine river: GCM-RCM uncertainty and separate temperature and precipitation effects, J. Hydrometeorol., 15, 697-713, doi:10.1175/JHM-D-12-098.1, 2014.

Boychenko, S. G.: Frequency of catastrophic climatic phenomena in Ukraine under the influence of global warming, in: Water Resources Systems - Hydrological Risk, Management and Development, edited by: Blöschl, G., Franks, S., Kumagai, M., Musiake, K., and Rosbjerg, D., IAHS Press, Wallingford, 281, 18-24, 2003.

Boychenko, S. G.: The scenarios of repeatability of catastrophic climatic phenomena in Europe and Ukraine under the influence of climatic changes (with use of historical records and manuscripts for the last millennium), Geofizicheskij Zhurnal, 32, 23-25, 2010 .
Brandt, M., Bergström, S., and Gardelin, M.: Modelling the effects of clearcutting on runoff - examples from central Sweden, Ambio, 17, 307-313, 1988.

Brath, A. and Montanari, A.: The effects of the spatial variability of soil infiltration capacity in distributed flood modelling, Hydrol. Process., 14, 2779-2794, doi:10.1016/j.jhydrol.2005.10.001, 2000.

Brath, A., Montanari, A., and Moretti, G.: Assessing the effect on flood frequency of land use change via hydrological simulation (with uncertainty), J. Hydrol., 324, 141-153, 2006.

Brázdil, R., Dobrovolný, P., Elleder, L., Kakos, V., Kotyza, O., Květoň, V., Macková, J., Müller, M., Štekl, J., Tolasz, R., and Valášek, H.: Historical and Recent Floods in the Czech Republic. Masaryk University, Czech Hydrometeorological Institute, Brno, Prague, 370 pp., 2005.

Brázdil, R., Kundzewicz, Z. W., and Benito, G.: Historical hydrology for studying flood risk in Europe, Hydrolog. Sci. J., 51, 739764, doi:10.1623/hysj.51.5.739, 2006.

Brázdil, R., Demarée, G. R., Deutsch, M., Garnier, E., Kiss, A., Luterbacher, J., Macdonald, N., Rohr, C., Dobrovolný, P., Koláŕ, P., and Chromá, K.: European floods during the winter 1783/1784: scenarios of an extreme event during the "Little Ice Age", Theor. Appl. Climatol., 100, 163-189, doi:10.1007/s00704-009-0170-5, 2010.

Brázdil, R., Kundzewicz, Z. W., Benito, G., Demarée, G., Macdonald, N., and Roald, L. A.: Historical floods in Europe in the past Millennium, in: Changes in Flood Risk in Europe, edited by: Kundzewicz, Z. W., IAHS Press, Wallingford, 121166, 2012.

Brigode, P., Oudin, L., and Perrin, C.: Hydrological model parameter instability: a source of additional uncertainty in estimating the hydrological impacts of climate change?, J. Hydrol., 476, 410 425, doi:10.1016/j.jhydrol.2012.11.012, 2013.

Bronstert, A., Niehoff, D., and Bürger, G.: Effects of climate and land use change on storm runoff generation: present knowledge and modelling capabilities, Hydrol. Process., 16, 509-529, doi:10.1002/hyp.326, 2002.

Bronstert, A., Bárdossy, A., Bismuth, C., Buiteveld, H., Disse, M., Engel, H., Fritsch, U., Hundecha, Y., Lammersen, R., Niehoff, D., and Ritter, N.: Multi-scale modelling of land use change and river training effects on floods in the Rhine basin, River Res. Appl., 23, 1102-1125, doi:10.1002/rra.1036, 2007.

Brown, A., Zhang, L., Mcmahon, T., Western, A., and Vertessy, R.: A review of paired catchment studies for determining changes in water yield resulting from alterations in vegetation, J. Hydrol., 310, 28-61, doi:10.1016/j.jhydrol.2004.12.010, 2005.

Brufau, P., Vázquez-Cendón, M. E., and García-Navarro, P.: A numerical model for the flooding and drying of irregular domains, Int. J. Numer. Meth. Fl., 39, 247-275, doi:10.1002/fld.285, 2002.

Brunsell, N. A.: A multiscale information theory approach to assess spatial-temporal variability of daily precipitation, J. Hydrol., 385, 165-172, doi:10.1016/j.jhydrol.2010.02.016, 2010.

Bulygina, N., McIntyre, N., and Wheater, H.: Conditioning rainfallrunoff model parameters for ungauged catchments and land management impacts analysis, Hydrol. Earth Syst. Sci., 13, 893-904, doi:10.5194/hess-13-893-2009, 2009.

Bulygina, N., McIntyre, N., and Wheater, H.: Bayesian conditioning of a rainfall-runoff model for predicting flows in ungauged 
catchments and under land use changes, Water Resour. Res., 47, W02503, doi:10.1029/2010WR009240, 2011.

Burn, D. H.: Catchment similarity for regional flood frequency analysis using seasonality measures, J. Hydrol., 202, 212-230, doi:10.1016/S0022-1694(97)00068-1, 1997.

Camuffo, D., Sturaro, G., and Benito, G.: An opposite flood pattern teleconnection between the Tagus (Iberian Peninsula) and Tiber (Italy) rivers during the last 1000 years, in: Palaeofloods, Historical Data and Climatic Variability: Applications in Flood Risk Assessment, edited by: Thorndycraft, V. R., Benito, G., Llasat, C., and Barriendos, M., Centro de Ciencias Medioambientales, Madrid, 295-300, 2003.

Chauveau, M., Chazot, S., Perrin, C., Bourgin, P.-Y., Sauquet, E., Vidal, J.-P., Rouchy, N., Martin, E., David, J., Norotte, T., Maugis, P., and de Lacaze, X.: What are the impacts of climate change on surface hydrology in France by 2070 ?, Houille Blanche, 4, 5-15, doi:10.1051//hb/2013027, 2013.

Chen, J., Brissette, F. P., and Leconte, R.: Uncertainty of downscaling method in quantifying the impact of climate change on hydrology, J. Hydrol., 401, 190-202, doi:10.1016/j.jhydrol.2011.02.020, 2011.

Chen, J., Brissette, F. P., Chaumont, D., and Braun, M.: Finding appropriate bias correction methods in downscaling precipitation for hydrologic impact studies over North America, Water Resour. Res., 49, 4187-4205, doi:10.1002/wrcr.20331, 2013.

Chen, Z. and Grasby, S. E.: Impact of decadal and century-scale oscillations on hydroclimate trend analyses, J. Hydrol., 365, 122133, doi:10.1016/j.jhydrol.2008.11.031, 2009.

Christensen, J. H. and Christensen, O. B.: A summary of the PRUDENCE model projections of changes in European climate by the end of this century, Climatic Change, 81, 7-30, doi:10.1007/s10584-006-9210-7, 2007.

Clarke, R. T.: How should trends in hydrological extremes be estimated?, Water Resour. Res., 49, 6756-6764, doi:10.1002/wrcr.20485, 2013a.

Clarke, R. T.: Calculating uncertainty in regional estimates of trend in streamflow with both serial and spatial correlations, Water Resour. Res., 49, 7120-7125, doi:10.1002/wrcr.20465, 2013b.

Cœr, D.: La plaine de Grenoble face aux inondations. Genèse d'une politique publique du XVIIe au XXe siècle. Èditions Quæ, Versailles Cedex, 2008

Cohen, S. J.: Bringing the global warming issue closer to home: the challenge of regional impact studies, B. Am. Meteorol. Soc., 71, 520-526, 1990.

Dahné, J., Donnelly, C., and Olsson, J.: Post-processing of climate projections for hydrological impact studies: how well is the reference state preserved?, in: Proceedings of H01, IAHSIAPSO-IASPEI Assembly, IAHS Publ. 359, Gothenburg, Sweden, July 2013.

Dankers, R. and Feyen, L.: Flood hazard in Europe in an ensemble of regional climate scenarios, J. Geophys. Res., 114, D16108, doi:10.1029/2008JD011523, 2009.

DeFries, R. and Eshleman, K.: land use change and hydrologic processes: a major focus for the future, Hydrol. Process., 18, $2183-$ 2186, doi:10.1002/hyp.5584, 2004.

Delgado, J. M., Apel, H., and Merz, B.: Flood trends and variability in the Mekong river, Hydrol. Earth Syst. Sci., 14, 407-418, doi:10.5194/hess-14-407-2010, 2010.
Delgado, J. M., Merz, B., and Apel, H.: A climate-flood link for the lower Mekong River, Hydrol. Earth Syst. Sci., 16, 1533-1541, doi:10.5194/hess-16-1533-2012, 2012.

Delgado, J. M., Merz, B., and Apel, H.: Projecting flood hazard under climate change: an alternative approach to model chains, Nat. Hazards Earth Syst. Sci., 14, 1579-1589, doi:10.5194/nhess-141579-2014, 2014.

De Roo, A., Schmuck, G., Perdigao, V., and Thielen, J.: The influence of historic land use changes and future planned land use scenarios on floods in the Oder catchment, Phys. Chem. Earth, 28, 1291-1300, doi:10.1016/j.pce.2003.09.005, 2003.

Diakakis, M.: An inventory of flood events in Athens, Greece, during the last 130 years, seasonality and spatial distribution, J. Flood Risk Manage., doi:10.1111/jfr3.12053, 2014.

Diakakis, M., Mavroulis, S., and Deligiannakis, G.: Floods in Greece, a statistical and spatial approach, Nat. Hazards, 62, 485500, doi:10.1007/s11069-012-0090-z, 2012.

Di Baldassarre, G., Castellarin, A., and Brath, A.: Analysis of the effects of levee heightening on flood propagation: example of the River Po, Italy, Hydrolog. Sci. J., 54, 1007-1017, doi:10.1623/hysj.54.6.1007, 2009.

Di Baldassarre, G., Montanari, A., Lins, H., Koutsoyiannis, D., Brandimarte, L., and Blöschl, G.: Flood fatalities in Africa: from diagnosis to mitigation, Geophys. Res. Lett., 37, L22402, doi:10.1029/2010GL045467, 2010.

Di Baldassarre, G., Kooy, M., Kemerink, J. S., and Brandimarte, L.: Towards understanding the dynamic behaviour of floodplains as human-water systems, Hydrol. Earth Syst. Sci., 17, 3235-3244, doi:10.5194/hess-17-3235-2013, 2013a.

Di Baldassarre, G., Viglione, A., Carr, G., Kuil, L., Salinas, J. L., and Blöschl, G.: Socio-hydrology: conceptualising humanflood interactions, Hydrol. Earth Syst. Sci., 17, 3295-3303, doi:10.5194/hess-17-3295-2013, 2013b.

Donnelly, C., Arheimer, B., Bosshard, T., and Pechlivanidis, I.: Uncertainties beyond ensembles and parameters - experiences of impact assessments using the HYPE model at various scales, in: Proceedings of Impacts World 2013, International Conference on Climate Change Effects, 27-30 May 2013, Potsdam, 2013.

Douglas, E. M., Vogel, R. M., and Kroll, C. N.: Trends in floods and low flows in the United States: impact of spatial correlation, J. Hydrol., 240, 90-105, doi:10.1016/S0022-1694(00)00336-X, 2000.

Ducharne, A., Sauquet, E., Habets, F., Déqué, M., Gascoin, S., Hachour, A., Martin, E., Oudin, L., Pagé, C., Terray, L., Thiéry, D., and Viennot, P.: Évolution potentielle du régime des crues de la Seine sous changement climatique - Potential evolution of the Seine River flood regime under climate change, Houille Blanche, 1, 51-57, doi:10.1051/lhb/2011006, 2011.

Dumas, P., Hallegatte, S., Quintana-Seguì, P., and Martin, E.: The influence of climate change on flood risks in France - first estimates and uncertainty analysis, Nat. Hazards Earth Syst. Sci., 13, 809-821, doi:10.5194/nhess-13-809-2013, 2013.

Eagleson, P. S.: Ecological optimality in water-limited natural soilvegetation systems, 1. Theory and hypothesis, Water Resour. Res., 18, 325-340, doi:10.1029/WR018i002p00325, 1982.

Elleder, L., Herget, J., Roggenkamp, T., and Nießen, A.: Historic floods in the city of Prague - a reconstruction of peak discharges for 1481-1825 based on documentary sources, Hydrol. Res., 44, 202-214, 2013. 
Erichsen, B. and Sælthun, N. R.: Climate change and energy production - statistical flood frequency analysis, NVE Publication 5, Norwegian Water Resources and Energy Administration, Oslo, 43 pp., 1995.

EU: Directive 2007/60/EC of the European Parliament and of the Council of 23 October 2007 on the assessment and management of flood risks, Official Journal of the European Union, L288, 2734, 2007.

Ewen, J., O’Donnell, G., Bulygina, N., Ballard, C., and O'Connell, E.: Towards understanding links between rural land management and the catchment flood hydrograph, Q. J. Roy. Meteor. Soc., 139, 350-357, doi:10.1002/qj.2026, 2013.

Falkenmark, M. and Chapman, T. (Eds.): Comparative Hydrology, UNESCO, Paris, France, 1989.

Fischer, A. M., Weigel, A. P., Buser, C. M., Knutti, R., Künsch, H. R., Liniger, M. A., Schär, C., and Appenzeller, C.: Climate Change Projections for Switzerland based on a Bayesian Climate Change Projections for Switzerland based on a Bayesian multi-model approach, Int. J. Climatol., 32, 23482371, doi:10.1002/joc.3396, 2012.

Fischer-Antze, T., Olsen, N. R. B., and Gutknecht, D.: Threedimensional CFD modeling of morphological bed changes in the Danube River, Water Resour. Res., 44, W09422, doi:10.1029/2007WR006402, 2008.

Foresight Land Use Futures Project: Final Project Report, The Government Office for Science, London, 325 pp., 2010.

Frei, C. and Schär, C.: Detection probability of trends in rare events: theory and application to heavy precipitation in the Alpine region, J. Climate, 14, 1568-1584, doi:10.1175/15200442(2001)014<1568:DPOTIR>2.0.CO;2. 2001.

Gaál, L., Szolgay, J., Kohnová, S., Parajka, J., Merz, R., Viglione, A., and Blöschl, G.: Flood timescales: understanding the interplay of climate and catchment processes through comparative hydrology, Water Resour. Res., 48, W04511, doi:10.1029/2011WR011509, 2012.

Gaume, E., Bain, V., Bernardara, P., Newinger, O., Barbuc, M., Bateman, A., Blaškovič, L., Blöschl, G., Borga, M., Dumitrescu, A., Daliakopoulos, I., Garcia, J., Irimescu, A., Kohnova, S., Koutroulis, A., Marchi, L., Matreata, S., Medina, V., Preciso, E., Sempere-Torres, D., Stancalie, G., Szolgay, J., Tsanis, I., Velasco, D., and Viglione, A.: A compilation of data on European flash floods, J. Hydrol., 367, 70-78, doi:10.1016/j.jhydrol.2008.12.028, 2009.

Gellens, D. and Roulin, E.: Streamflow response of Belgian catchments to IPCC climate change scenarios, J. Hydrol., 210, 242258, doi:10.1016/S0022-1694(98)00192-9, 1998.

Gerten, D., Schaphoff, S., Haberlandt, U., Lucht, W., and Sitch, S.: Terrestrial vegetation and water balance - hydrological evaluation of a dynamic global vegetation model, J. Hydrol., 286, 249270, doi:10.1016/j.jhydrol.2003.09.029, 2004.

Giorgi, F. and Mearns, L. O.: Introduction to special section: regional climate modeling revisited, J. Geophys. Res., 104, 63356352, doi:10.1029/98JD02072, 1999.

Giuntoli, I., Renard, B., and Lang, M.: Chapter 10: Floods in France, in: Changes in Flood Risk in Europe, edited by: Kundzewicz, Z. W., IAHS Press, Wallingford, 199-211, 2012.

Glaser, R., Riemann, D., Schönbein, J., Barriendos, M., Brázdil, R., Bertolin, C., Camuffo, D., Deutsch, M., Dobrovolný, P., van Engelen, A., Enzi, S., Halíčková, M., Koenig, S. J., Kotyza, O., Li- manowka, D., Macková, J., Sghedoni, M., Martin, B., and Himmelsbach, I.: The variability of European floods since AD 1500, Climatic Change, 101, 235-256, doi:10.1007/s10584-010-98167, 2010.

Gray, L. K. and Hamann, A.: Tracking suitable habitat for tree populations under climate change in western North America, Climatic Change, 117, 289-303, doi:10.1007/s10584-012-0548-8, 2012.

Grayson, R., Blöschl, G., Western, A., and McMahon, T.: Advances in the use of observed spatial patterns of catchment hydrological response, Adv. Water Resour., 25, 1313-1334, doi:10.1016/S0309-1708(02)00060-X, 2002.

Green, J. C.: Modelling flow resistance in vegetated streams: review and development of new theory, Hydrol. Process., 19, 12451259, doi:10.1002/hyp.5564, 2005.

Gurnell, A. M. and Petts, G. E.: Island-dominated landscapes of large floodplain rivers, a European perspective, Freshwater Biol., 47, 581-600, doi:10.1046/j.1365-2427.2002.00923.x, 2002.

Hall, J. and Murphy, C.: Robust adaptation assessment - climate change and water supply, Int. J. Clim. Change Strat. Manage., 3, 302-319, doi:10.1108/17568691111153438, 2011.

Hanewinkel, M., Cullmann, D. A., Schelhaas, M.-J., Nabuurs, G.J., and Zimmermann, N. E.: Climate change may cause severe loss in the economic value of European forest land, Nat. Clim. Change, 3, 203-207, doi:10.1038/nclimate1687, 2012.

Hannaford, J. and Buys, G.: Trends in seasonal river flow regimes in the UK, J. Hydrol., 475, 158-174, doi:10.1016/j.jhydrol.2012.09.044, 2012.

Hannaford, J. and Marsh, T. J.: High-flow and flood trends in a network of undisturbed catchments in the UK, Int. J. Climatol., 28, 1325-1338, doi:10.1002/joc.1643, 2008.

Hannaford, J., Holmes, M., Laizé, C., Marsh, T., and Young, A.: Evaluating hydrometric networks for prediction in ungauged basins: a new methodology and its application to England and Wales, Hydrol. Res., 44, 401-418, doi:10.2166/nh.2012.115, 2012.

Hannaford, J., Buys, G., Stahl, K., and Tallaksen, L. M.: The influence of decadal-scale variability on trends in long European streamflow records, Hydrol. Earth Syst. Sci., 17, 2717-2733, doi:10.5194/hess-17-2717-2013, 2013.

Hannah, D. M., Demuth, S., van Lanen, H. A. J., Looser, U., Prudhomme, C., Rees, G., Stahl, K., and Tallaksen, L. M.: Large-scale river flow archives: importance, current status and future needs, Hydrol. Process., 25, 1191-1200, doi:10.1002/hyp.7794, 2011.

Harrigan, S., Murphy, C., Hall, J., Wilby, R. L., and Sweeney, J.: Attribution of detected changes in streamflow using multiple working hypotheses, Hydrol. Earth Syst. Sci., 18, 1935-1952, doi:10.5194/hess-18-1935-2014, 2014.

Harvey, C. L., Dixon, H., and Hannaford, J.: An appraisal of the performance of data-infilling methods for application to daily mean river flow records in the UK, Hydrol. Res., 43, 618-636, doi:10.2166/nh.2012.110, 2012.

Hawkins, E. and Sutton, R.: The potential to narrow uncertainty in regional climate predictions, B. Am. Meteorol. Soc., 90, 10951107, doi:10.1175/2009BAMS2607.1, 2009.

Helms, M., Ihringer, J., and Mikovec, R.: Hydrological simulation of extreme flood scenarios for operational flood management at the Middle Elbe river, Adv. Geosci., 32, 41-48, doi:10.5194/adgeo-32-41-2012, 2012. 
Herget, J. and Meurs, H.: Reconstructing peak discharges for historic flood levels in the city of Cologne, Germany, Global Planet. Change, 70, 108-116, doi:10.1016/j.gloplacha.2009.11.011, 2010.

Hirabayashi, Y., Kanae, S., Emori, S., Oki, T., and Kimoto, M.: Global projections of changing risks of floods and droughts in a changing climate, Hydrolog. Sci. J., 53, 754-772, doi:10.1623/hysj.53.4.754, 2008.

Hisdal, H., Roald, L. A., and Beldring, S.: Past and future changes in flood and drought in the Nordic countries, in: Climate Variability and Change: Hydrological Impacts, Publ. No. 308, edited by: Demuth, S., Gustard, A., Planos, E., Seatena, F., and Servat, E., IAHS Press, Wallingford, 502-507, 2006.

Hohenegger, C., Brockhaus, P., and Schär, C.: Towards climate simulations at cloud-resolving scales, Meteorol. Z., 17, 383-394, doi:10.1127/0941-2948/2008/0303, 2008.

Hohenegger, C., Brockhaus, P., Bretherton, C.S. and Schär, C.: The soil moisture-precipitation feedback in simulations with explicit and parameterized convection. J. Climatol., 22, 5003-5020, doi:10.1175/2009JCLI2604.1, 2009.

Hollaus, M., Aubrecht, C., Höfle, B., Steinnocher, K., and Wagner, W.: Roughness mapping on various vertical scales based on fullwaveform airborne laser scanning data, Remote Sens., 3, 503523, doi:10.3390/rs3030503, 2011.

Hooijer, A., Klijn, F., Pedroli, G. B. M., and Van Os, A. G.: Towards sustainable flood risk management in the Rhine and Meuse river basins: synopsis of the findings of IRMA-SPONGE, River Res. Appl., 20, 343-357, doi:10.1002/rra.781, 2004.

Hrachowitz, M., Savenije, H. H. G., Blöschl, G., McDonnell, J. J., Sivapalan, M., Pomeroy, J. W., Arheimer, B., Blume, T., Clark, M. P., Ehret, U., Fenicia, F., Freer, J. E., Gelfan, A., Gupta, H. V., Hughes, D. A., Hut, R. W., Montanari, A., Pande, S., Tetzlaff, D., Troch, P. A., Uhlenbrook, S., Wagener, T., Winsemius, H. C., Woods, R. A., Zehe, E., and Cudennec, C.: A decade of Predictions in Ungauged Basins (PUB) - a review, J. Hydrol. Sci., 58, 1198-1255, doi:10.1080/02626667.2013.803183, 2013.

Huang, S., Hattermann, F. F., Krysanova, V., and Bronstert, A.: Projections of climate change impacts on river flood conditions in Germany by combining three different RCMs with a regional eco-hydrological model, Climatic Change, 116, 631-663, doi:10.1007/s10584-012-0586-2, 2013.

Hundecha, Y. and Bárdossy, A.: Modeling of the effect of land use changes on the runoff generation of a river basin through parameter regionalization of a watershed model, J. Hydrol., 292, 281-295, doi:10.1016/j.jhydrol.2004.01.002, 2004.

Hundecha, Y. and Merz, B.: Exploring the relationship between changes in climate and floods using a model-based analysis, Water Resour. Res., 48, W04512, doi:10.1029/2011WR010527, 2012.

Hundecha, Y., Ouarda, T. B. M. J., and Bárdossy, A.: Regional estimation of parameters of a rainfall-runoff model at ungauged watersheds using the "spatial" structures of the parameters within a canonical physiographic-climatic space, Water Resour. Res., 44, W01427, doi:10.1029/2006WR005439, 2008.

Huntington, T. G.: Evidence for intensification of the global water cycle: review and synthesis, J. Hydrol., 319, 83-95, doi:10.1016/j.jhydrol.2005.07.003, 2006.

Hurst, H. E.: Long term storage capacity of reservoirs, T. Am. Soc. Civ. Eng., 116, 770-779, 1951.
IPCC: Summary for policymakers, in: Climate Change 2013: The Physical Science Basis, Contribution of Working Group I to the Fifth Assessment Report of the Intergovernmental Panel on Climate Change, edited by: Stocker, T. F., Qin, D., Plattner, G.-K., Tignor, M., Allen, S. K., Boschung, J., Nauels, A., Xia, Y., Bex, V., and Midgley, P. M., Cambridge University Press, Cambridge, UK and New York, USA, 2013.

Jackson, B., Chell, J., Francis, O., Frogbrook, Z., Marshall, M., Mcintyre, N., Reynolds, B., Solloway, I., and Wheater, H.: The impact of upland land management on flooding: insights from a multi-scale experimental and modelling programme, J. Flood Risk Manage., 1, 71-80, doi:10.1111/j.1753318X.2008.00009.x, 2008.

Jackson, B., Pagella, T., Sinclair, F., Orellana, B., Henshaw, A., Reynolds, B., Mcintyre, N., Wheater, H., and Eycott, A.: Polyscape: a GIS mapping toolbox providing efficient and spatially explicit landscape-scale valuation of multiple ecosystem services, Urban Landscape Plan., 112, 74-88, doi:10.1016/j.landurbplan.2012.12.014, 2013.

Janža, M.: Impact assessment of projected climate change on the hydrological regime in the SE Alps, Upper Soĉa River basin, Slovenia, Nat. Hazards, 67, 1025-1043, doi:10.1007/s11069011-9892-7, 2011.

Jones, C., Giorgi, F., and Asrar, G.: The Coordinated Regional Downscaling Experiment: CORDEX - an international downscaling link to CMIP5, CLIVAR Exchanges, 56, 34-40, 2011.

Kaczmarek, Z.: The impact of climate variability on flood risk in Poland, Risk Anal., 23, 559-566, doi:10.1111/1539-6924.00336, 2003.

Kay, A. L. and Jones, D. A.: Transient changes in flood frequency and timing in Britain under potential projections of climate change, Int. J. Climatol., 32, 489-502, doi:10.1002/joc.2288, 2012.

Khaliq, M., Ouarda, T., Gachon, P., Sushama, L., and St-Hilaire, A.: Identification of hydrological trends in the presence of serial and cross correlations: A review of selected methods and their application to annual flow regimes of Canadian rivers, J. Hydrol., 368, 117-130, doi:10.1016/j.jhydrol.2009.01.035, 2009.

Kiss, A.: Floods and weather in 1342 and 1343 in the Carpathian basin, J. Environ. Geogr., 2, 37-47, 2009.

Kiss, A. and Laszlovszky, J.: 14th-16th-century Danube floods and long-term waterlevel changes in archaeological and sedimentary evidence in the western and central Carpathian Basin: an overview with documentary comparison, J. Environ. Geogr., 6, 1-11, 2013a.

Kiss, A. and Laszlovszky, J.: Árvízhullámok a Dunán? A Duna árvizei és a visegrádi ferences kolostor a késő középkorban és a kora újkorban, Korall, 36, 36-65, 2013b.

Kiss, A.: Árvizek és magas vízszintek a 13-15, századi Magyarországon az egykorú írott források tükrében: Megfoghatóke és mi alapján foghatók meg rövid, közép és hosszú távú változások? - Floods and high water levels in 13th-15th-century Hungary, in the light of contemporary documentary evidence, is it possible to detect short-, medium- and long-term changes?, in: Környezettörténet 2 - Environmental history 2, edited by: Kázmér, M., Hantken Kiadó, Budapest, 43-55, 2011.

Kiss, A.: Dunai árvizek Magyarországon a középkori írott források tükrében: 1000-1500, Esettanulmányok, forráskritika és elemzési problémák (Danube floods in Hungary in medieval 
documentary evidence: $1000-1500$, case studies, source critics and analysis problems), in: Középkortörténeti tanulmányok 7 Research in medieval studies 7, edited by: Kiss, A., Piti, F., and Szabados, G., Középkorász Múhely, Szeged, 339-355, 2012.

Kjeldsen, T. R.: COST Action ES0901: European procedures for flood frequency estimation (FloodFreq), in: Geophys. Res. Abstr., European Geophysical Union, 13, EGU2011-10327, 2011.

Klimenko, V. and Solomina, O.: Climatic variations in the East European Plain during the last Millennium: state of the art, in: The Polish Climate in the European Context: an Historical Overview, edited by: Przybylak, R., Majorowicz, J., Brázdil, R., and Kejna, M., Springer, Dordrecht, 71-101, doi:10.1007/978-90-4813167-9_3, 2010.

Klöcking, B. and Haberlandt, U.: Impact of land use changes on water dynamics - a case study in temperate meso and macroscale river basins, Phys. Chem. Earth, 27, 619-629, doi:10.1016/S1474-7065(02)00046-3, 2002.

Kondolf, M. G., Piegay, H., and Landon, N.: Channel response to increased and decreased bedload supply from land use change since 1900: contrasts between catchments in the Rocky Mountains of Idaho and the Pre-Alps of France, Geomorphology, 45, 35-51, 2002.

Köplin, N., Schädler, B., Viviroli, D., and Weingartner, R.: Seasonality and magnitude of floods in Switzerland under future climate change, Hydrol. Process., 28, 2567-2578, doi:10.1002/hyp.9757, 2014.

Korhonen, J. and Kuusisto, E.: Long-term changes in the discharge regime in Finland, Hydrol. Res., 41, 253-268, doi:10.2166/nh.2010.112, 2010.

Kostka, Z. and Holko, L.: Role of forest in hydrological cycle forest and runoff, Meteorol. J., 3, 143-148, 2006.

Koutsoyiannis, D. and Montanari, A.: Statistical analysis of hydroclimatic time series: uncertainty and insights, Water Resour. Res., 43, W05429, doi:10.1029/2006WR005592, 2007.

Kovács, A., Honti, M., Eder, A., Zessner, M., Clement, A., and Blöschl, G.: Identification of phosphorus emission hotspots in agricultural catchments, Sci. Total Environ., 433, 74-88, doi:10.1016/j.scitotenv.2012.06.024, 2012.

Krámer, T. and Józsa, J.: An overview of river floodplain modelling, Budapest University of Technology and Economics, available at: http://vit.bme.hu/targyak/mundus_3rd/ vedett/mundusfloodsimulation.pdf (last access: December 2013), 2004.

Kriaučiūnienė, J., Meilutytė-Barauskienè, D., Reihan, A., Koltsova, T., Lizuma, L., and Šarauskienè, D.: Variability in temperature, precipitation and river discharge in Baltic States, Boreal Environ. Res., 17, 150-162, 2012.

Kundzewicz, Z. W. and Robson, A. J.: Change detection in hydrological records - a review of the methodology, Hydrolog. Sci. J., 49, 7-19, doi:10.1623/hysj.49.1.7.53993, 2004.

Kundzewicz, Z. W., Lugeri, N., Dankers, R., Hirabayashi, Y., Döll, P., Pinskwar, I., Dysarz, T., Hochrainer, S., and Matczak, P.: Assessing river flood risk and adaptation in Europe - review of projections for the future, Mitig. Adapt. Strat. Global Change, 15, 641-656, doi:10.1007/s11027-010-9213-6, 2010.

Kundzewicz, Z. W., Dobrowolski, A., Lorenc, H., Niedźwiedź, T., Pińskwar, I., and Kowalczak, P.: Floods in Poland, in: Changes in Flood Risk in Europe, edited by: Kundzewicz, Z. W., IAHS Press, Wallingford, UK, 319-334, 2012.
Kundzewicz, Z. W., Pinskwar, I., and Brakenridge, G. R.: Large floods in Europe, 1985-2009, Hydrolog. Sci. J., 58, 1-7, doi:10.1080/02626667.2012.745082, 2013.

Kuusisto, E.: Hydrology at research institutes, Geophysica, 37, 189-198, 2001.

Kwon, H. H., Brown, C., and Lall, U.: Climate informed flood frequency analysis and prediction in Montana using hierarchical Bayesian modeling, Geophys. Res. Lett., 35, L05404, doi:10.1029/2007GL032220, 2008.

Laio, F., Di Baldassarre, G., and Montanari, A.: Model selection techniques for the frequency analysis of hydrological extremes, Water Resour. Res., 45, W07416, doi:10.1029/2007WR006666, 2009.

Lammersen, R., Engel, H., Van de Langemheen, W., and Buiteveld, H.: Impact of river training and retention measures on flood peaks along the Rhine, J. Hydrol., 267, 115-124, doi:10.1016/S0022-1694(02)00144-0, 2002.

Lara, A., Saurí, D., Ribas, A., and Pavón, D.: Social perceptions of floods and flood management in a Mediterranean area (Costa Brava, Spain), Nat. Hazards Earth Syst. Sci., 10, 2081-2091, doi:10.5194/nhess-10-2081-2010, 2010.

Leander, R., Buishand, T. A., van den Hurk, B. J., and de Wit, M. J.: Estimated changes in flood quantiles of the river Meuse from resampling of regional climate model output, J. Hydrol., 351, 331343, doi:10.1016/j.jhydrol.2007.12.020, 2008.

Lehner, B., Döll, P., Alcamo, J., Henrichs, T., and Kaspar, F.: Estimating the impact of global change on flood and drought risks in Europe: a continental, integrated analysis, Climatic Change, 75, 273-299, doi:10.1007/s10584-006-6338-4, 2006.

Liang, Q. and Marche, F.: Numerical resolution of well-balanced shallow water equations with complex source terms, Adv. Water Resour., 32, 873-884, doi:10.1016/j.advwatres.2009.02.010, 2009.

Lindström, G. and Alexandersson, H.: Recent mild and wet years in relation to long observation records and climate change in Sweden, Ambio, 33, 183-186, 2004.

Llasat, M.-C., Barriendos, M., Barrera, A., and Rigo, T.: Floods in Catalonia (NE Spain) since the 14th century, climatological and meteorological aspects from historical documentary sources and old instrumental records, Special issue: Applications of palaeoflood hydrology and historical data in flood risk analysis, J. Hydrol., 313, 32-47, doi:10.1016/j.jhydrol.2005.02.004, 2005.

Llasat, M. C., Llasat-Botija, M., Rodriguez, A., and Lindbergh, S.: Flash floods in Catalonia: a recurrent situation, Adv. Geosci., 26 , 105-111, doi:10.5194/adgeo-26-105-2010, 2010.

López-Moreno, J. I., Begueria, S., and Garca-Ruiz, J. M.: Trends in high flows in the central Spanish Pyrenees: response to climatic factors or to land use change?, Hydrolog. Sci. J., 51, 1039-1050, doi:10.1623/hysj.51.6.1039, 2006.

Macdonald, N.: Epigraphic records: a valuable resource in reassessing flood risk and long-term climate variability, Environ. Hist., 12, 136-140, 2007.

Macdonald, N.: Trends in flood seasonality of the River Ouse (northern England), from archive and instrumental sources since AD 1600, Climatic Change, 110, 901-923, doi:10.1007/s10584011-0117-6, 2012.

Macdonald, N.: Reassessing flood frequency for the River Trent, central England, since AD 1320, Hydrol. Res., 44, 215-233, doi:10.2166/nh.2012.188, 2013. 
Macdonald, N. and Black, A. R.: Reassessment of flood frequency using historical information for the River Ouse at York, UK (1200-2000), Hydrolog. Sci. J., 55, 1152-1162, doi:10.1080/02626667.2010.508873, 2010.

Macdonald, N., Black, A. R., Werritty, A., and McEwen, L. J.: Historical and pooled flood frequency analysis for the River Tay at Perth, Scotland, Area, 38, 34-46, doi:10.1111/j.14754762.2006.00673.x, 2006.

Macdonald, N., Phillips, I. D., and Bale, G.: Spatial and temporal variability of flood seasonality in Wales, Hydrol. Process., 24, 1806-1820, doi:10.1002/hyp.7618, 2010.

Markart, G., Kohl, B., Sotier, B., Schauer, T., Bunza, G., and Stern, R.: Provisorische Geländeanleitung zur Abschätzung des Oberflächenabflussbeiwertes auf alpinen Boden-/Vegetationseinheiten bei konvektiven Starkregen A Simple Code of Practice for Assessment of Surface Runoff Coefficients for Alpine Soil-/Vegetation Units in Torrential Rain, BFW-Dokumentation, Schriftenreihe des Bundesamtes und Forschungszentrums für Wald, Wien, 3, 88 pp., 2004.

Markonis, Y. and Koutsoyiannis, D.: Climatic variability over time scales spanning nine orders of magnitude: connecting Milankovitch Cycles with Hurst-Kolmogorov Dynamics, Surv. Geophys., 34, 181-207, doi:10.1007/s10712-012-9208-9, 2012.

Marsh, T.: A hydrological overview of the summer 2007 floods in England and Wales, Weather, 63, 274-279, doi:10.1002/wea.305, 2008.

Matalas, N. C. and Langbein, W. B.: Information content of the mean, J. Geophys. Res., 67, 3441-3448, doi:10.1029/JZ067i009p03441, 1962.

McIntyre, N. and Marshall, M.: Identification of rural land management signals in runoff response, Hydrol. Process., 24, 35213534, doi:10.1002/hyp.7774, 2010.

McIntyre, N., Ballard, C., Bulygina, N., Frogbrook, Z., Cluckie, I., Dangerfield, S., and Ewen, J.: The potential for reducing flood risk through changes to rural land management: outcomes from the Flood Risk Management Research Consortium, in: British Hydrological Society's Eleventh National Symposium, Hydrology for a changing world, 9-11 July, Dundee, 2012.

McIntyre, N., Ballard, C., Bruen, M., Bulygina, N., Buytaert, W., Cluckie, I., Dunn, S., Ehret, U., Ewen, J., Gelfan, A., Hess, T., Hughes, D., Jackson, B., Kjledsen, T., Merz, B., Park, J.-S., O'Connell, E., O’Donnell, G., Oudin, L., Todini, E., Wagener, T., and Wheater, H.: Modelling the hydrological impacts of rural land use change, Hydrol. Res., doi:10.2166/nh.2013.145, in press, 2014.

Mediero, L., Santillán, D., Garrote, L., and Granados, A.: Detection and attribution of trends in magnitude, frequency and timing of floods in Spain, J. Hydrol., 517, 1072-1088, doi:10.1016/j.jhydrol.2014.06.040, 2014.

Merz, R. and Blöschl, G.: A process typology of regional floods, Water Resour. Res., 39, 1340-1359, doi:10.1029/2002WR001952, 2003.

Merz, R. and Blöschl, G.: Flood frequency hydrology: 1. Temporal, spatial, and causal expansion of information, Water Resour. Res., 44, W08432, doi:10.1029/2007WR006744, 2008a.

Merz, R. and Blöschl, G.: Flood frequency hydrology: 2. Combining data evidence, Water Resour. Res., 44, W08433, doi:10.1029/2007WR006745, 2008b.
Merz, R. and Blöschl, G.: A regional analysis of event runoff coefficients with respect to climate and catchment characteristics in Austria, Water Resour. Res., 45, W01405, doi:10.1029/2008WR007163, 2009.

Merz, R., Piock-Ellena, U., Blöschl, G., and Gutknecht, D.: Seasonality of flood processes in Austria, in: Hydrological Extremes: Understanding, Predicting, Mitigating, edited by: Gottschalk, L., Olivry, J.-C., Reed, D., and Rosbjerg, D., IAHS Press, Wallingford, UK, 273-278, 1999.

Merz, R., Blöschl, G., Piock-Ellena, U., and Rieger, W.: Regionalisierung von Bemessungshochwässern mit geostatistischen Verfahren - Regional estimation of design floods by geostatistical techniques, Vol. 1, Interpraevent 2000, 26-30 June 2000, Villach, Austria, 71-84, 2000.

Merz, R., Blöschl, G., and Humer, G.: National flood discharge mapping in Austria, Nat. Hazards, 46, 53-72, doi:10.1007/s11069-007-9181-7, 2008.

Merz, R., Parajka, J., and Blöschl, G.: Time stability of catchment model parameters - implications for climate impact analyses, Water Resour. Res., 47, W02531, doi:10.1029/2010WR009505, 2011.

Merz, B., Vorogushyn, S., Uhlemann, S., Delgado, J., and Hundecha, Y.: HESS Opinions "More efforts and scientific rigour are needed to attribute trends in flood time series", Hydrol. Earth Syst. Sci., 16, 1379-1387, doi:10.5194/hess-16-13792012, 2012.

Merz, B., Aerts, J., Arnbjerg-Nielsen, K., Baldi, M., Becker, A., Bichet, A., Blöschl, G., Bouwer, L. M., Brauer, A., Cioffi, F., Delgado, J. M., Gocht, M., Guzzetti, F., Harrigan, S., Hirschboeck, K., Kilsby, C., Kron, W., Kwon, H.-H., Lall, U., Merz, R., Nissen, K., Salvati, P., Swierczynski, T., Ulbrich, U., Viglione, A., Ward, P. J., Weiler, M., Wilhelm, B., and Nied, M.: Floods and climate: emerging perspectives for flood risk assessment and management, Nat. Hazards Earth Syst. Sci., 14, 19211942, doi:10.5194/nhess-14-1921-2014, 2014.

Midttømme, G. H. and Tingvold, J. K.: Historic extreme floods as input to dam safety analyses, in: The Extremes of the Extreme: Extraordinary Floods, edited by: Snorrason, A., Finnsdottir, H. P., and Moss, M. E., Publ. No. 271, IAHS Press, Wallingford, UK, 155-159, 2002.

Millán, M. M., Estrela, M. J., Sanz, M. J., Mantilla, E., Martín, M., Pastor, F., Salvador, R., Vallejo, R., Alonso, L., Gangoiti, G., Ilardia, J. L., Navazo, M., Albizuri, A., Artíñano, B., Ciccioli, P., Kallos, G., Carvalho, R. A., Andrés, D., Hoff, A., Werhahn, J., Seufert, G., and Versino, B.: Climatic feedbacks and desertification: the Mediterranean model, J. Climate, 18, 684-701, doi:10.1175/JCLI-3283.1, 2005.

Mitková, V.: Travel time changes of the flood on Danube River, Acta Hydrol. Slovaca, 3, 20-27, 2002.

Molnar, P., Burlando, P., and Ruf, W.: Integrated catchment assessment of riverine landscape dynamics, Aquat. Sci., 64, 129-140, doi:10.1007/s00027-002-8061-1, 2002.

Montanari, A.: Hydrology of the Po River: looking for changing patterns in river discharge, Hydrol. Earth Syst. Sci., 16, 37393747, doi:10.5194/hess-16-3739-2012, 2012.

Montanari, A. and Koutsoyiannis, D.: A blueprint for process-based modeling of uncertain hydrological systems, Water Resour. Res., 48, W09555, doi:10.1029/2011WR011412, 2012. 
Montanari, A., Rosso, R., and Taqqu, M. S.: Fractionally differenced ARIMA models applied to hydrologic time series: identification, estimation and simulation, Water Resour. Res., 33, 10351044, doi:10.1029/97WR00043, 1997.

Montanari, A., Taqqu, M. S., and Teverovsky, V.: Estimating longrange dependence in the presence of periodicity: an empirical study, Math. Comput. Model., 29, 217-228, doi:10.1016/S08957177(99)00104-1, 1999.

Montanari, A., Shoemaker, C. A., and van de Giesen, N.: Introduction to special section on uncertainty assessment in surface and subsurface hydrology: an overview of issues and challenges, Water Resour. Res., 45, W00B00, doi:10.1029/2009WR008471, 2009.

Montanari, A., Young, G., Savenije, H. H. G., Hughes, D., Wagener, T., Ren, L. L., Koutsoyiannis, D., Cudennec, C., Toth, E., Grimaldi, S., Blöschl, G., Sivapalan, M., Beven, K., Gupta, H., Hipsey, M., Schaefli, B., Arheimer, B., Boegh, E., Schymanski, S. J., Di Baldassarre, G., Yu, B., Hubert, P., Huang, Y., Schumann, A., Post, D., Srinivasan, V., Harman, C., Thompson, S., Rogger, M., Viglione, A., McMillan, H., Characklis, G., Pang, Z., and Belyaev, V.: "Panta Rhei - everything flows": change in hydrology and society - the IAHS scientific decade 2013-2022, Hydrolog. Sci. J., 58, 1256-1275, doi:10.1080/02626667.2013.809088, 2013.

Morán-Tejeda, E., López-Moreno, J. I., Vicente-Serrano, S. M., Lorenzo-Lacruz, J., and Ceballos-Barbancho, A.: The contrasted evolution of high and low flows and precipitation indices in the Duero basin (Spain), Hydrolog. Sci. J., 57, 591-611, doi:10.1080/02626667.2012.673722, 2012.

Mudelsee, M., Börngen, M., Tetzlaff, G., and Grünewald, U.: No upward trends in the occurrence of extreme floods in central Europe, Nature, 425, 166-169, doi:10.1038/nature01928, 2003.

Murillo, J., García-Navarro, P., Burguete, J., and Brufau, P.: The influence of source terms on stability, accuracy and conservation in two-dimensional shallow flow simulation using triangular finite volumes, Int. J. Numer. Meth. Fl., 54, 543-590, doi:10.1002/fld.1417, 2007.

Murphy, C., Harrigan, S., Hall, J., and Wilby, R.: Climate driven trends in mean- and high- flows from a network of reference stations in Ireland, Hydrolog. Sci. J., 58, 755-772, doi:10.1080/02626667.2013.782407, 2013.

Murphy, J. M., Booth, B., Collins, M., Harris, G., Sexton, D., and Webb, M.: A methodology for probabilistic predictions of regional climate change from perturbed physics ensembles, Philos. T. Roy. Soc. A, 365, 1993-2028, doi:10.1098/rsta.2007.2077, 2007.

Naef, F., Scherrer, S., and Weiler, M.: A process based assessment of the potential to reduce flood runoff by land use change, J. Hydrol., 267, 74-79, doi:10.1016/S0022-1694(02)00141-5, 2002.

Naulet, R., Lang, M., Ouarda, T., Coeur, D., Bobée, B., Recking, A., and Moussay, D.: Flood frequency analysis on the Ardèche river using French documentary sources from the two last centuries, J. Hydrol., 312, 58-78, doi:10.1016/j.jhydrol.2005.02.011, 2005.

Nepf, H. M.: Flow and transport in regions with aquatic vegetation, Annu. Rev. Fluid Mech., 44, 123-142, doi:10.1146/annurevfluid-120710-101048, 2012.

Nester, T., Kirnbauer, R., Parajka, J., and Blöschl, G.: Evaluating the snow component of a flood forecasting model, Hydrol. Res., 43, 762-779, doi:10.2166/nh.2012.041, 2012a.
Nester, T., Komma, J., Viglione, A., and Blöschl, G.: Flood forecast errors and ensemble spread - a case study, Water Resour. Res., 48, W10502, doi:10.1029/2011WR011649, 2012b.

Nicolis, C. and Nicolis, G.: Is there a climatic attractor?, Nature, 311, 529-532, doi:10.1038/311529a0, 1984.

Nicolis, C., Perdigão, R. A. P., and Vannitsem, S.: Dynamics of prediction errors under the combined effect of initial condition and model errors, J. Atmos. Sci., 88, 766-778, doi:10.1175/2008JAS2781.1, 2009.

Niehoff, D., Fritsch, U., and Bronstert, A.: land use impacts on storm-runoff generation: scenarios of land use change and simulation of hydrological response in a meso-scale catchment in SW-Germany, J. Hydrol., 267, 80-93, doi:10.1016/S00221694(02)00142-7, 2002.

Nilsson, C., Reidy, C. A., Dynesius, M., and Revenga, C.: Fragmentation and flow regulation of the world's large river systems, Science, 308, 405-408, doi:10.1126/science.1107887, 2005.

Nováky, B. and Bálint, G.: Shifts and modification of the hydrological regime under climate change in Hungary, in: Climate Change - Realities, Impacts Over Ice Cap, Sea Level and Risks, edited by: Singh, B. R., InTechOpen, 163-190, doi:10.5772/54768, 2013.

O'Connell, P. E., Beven, K., Carney, J. N., Clements, R. O., Ewen, J., Fowler, H., Harris, G., Hollis, J., Morris, J., O’Donnell, G. M. O., Packman, J. C., Parkin, A., Quinn, P. F., Rose, S. C., Shepher, M., and Tellier, S.: Review of Impacts of Rural Land Use and Management on Flood Generation, RandD Q18 Technical Report FD2114/TR, DEFRA, London, 152 pp., 2004.

O'Connell, P. E., Ewen, J., O’Donnell, G., and Quinn, P.: Is there a link between agricultural land use management and flooding?, Hydrol. Earth Syst. Sci., 11, 96-107, doi:10.5194/hess-11-962007, 2007.

Önöz, B. and Bayazit, M.: Block bootstrap for Mann-Kendall trend test of serially dependent data, Hydrol. Process., 26, 3552-3560, doi:10.1002/hyp.8438, 2012.

Palmer, T. N.: Predicting uncertainty in forecasts of weather and climate, Rep. Prog. Phys., 63, 71-116, doi:10.1088/00344885/63/2/201, 2000.

Parajka, J., Kohnová, S., Merz, R., Szolgay, J., Hlavová, K., and Blöschl, G.: Comparative Analysis of the seasonality of hydrological characteristics in Slovakia and Austria, Hydrolog. Sci. J., 54, 456-473, doi:10.1623/hysj.54.3.456, 2009.

Parajka, J., Kohnová, S., Bálint, G., Barbuc, M., Borga, M., Claps, P., Cheval, S., Dumitrescu, A., Gaume, E., Hlavová, K., Merz, R., Pfaundler, M., Stancalie, G., Szolgay, J., and Blöschl G.: Seasonal characteristics of flood regimes across the Alpine-Carpathian range, J. Hydrol., 394, 78-89, doi:10.1016/j.jhydrol.2010.05.015, 2010.

Parajka, J., Andréassian, J., Archfield, S., Bárdossy, A., Chiew, F., Duan, Q., Gelfan, A., Hlavčová, K., Merz, R., McIntyre, N., Oudin, L., Perrin, C., Rogger, M., Salinas, J.-L., Savenije, H., Skøien, J.-O., Wagener, T., Zehe, E., and Zhang, Y.: Predictions of runoff hydrographs in ungauged basins (Chapter 10), in: Runoff Prediction in Ungauged Basins: Synthesis across Processes, Places and Scales, edited by: Blöschl, G., Sivapalan, M., Wagener, T., Viglione, A., and Savenije, H., Cambridge University Press, 484 pp., 2013. 
Parent, E. and Bernier, J.: Bayesian POT modelling for historical data, J. Hydrol., 274, 95-108, doi:10.1016/S00221694(02)00396-7, 2003.

Pattison, I. and Lane, S. N.: The link between land use management and fluvial flood risk: a chaotic conception?, Prog. Phys. Geogr., 36, 72-92, doi:10.1177/0309133311425398, 2012.

Peel, M. C. and Blöschl, G.: Hydrologic modelling in a changing world, Prog. Phys. Geogr., 35, 249-261, doi:10.1177/0309133311402550, 2011.

Pekárová, P., Pacl, J., Liová, S., Miklánek, P., Škoda, P., and Pekár, J.: Analysis of the maximum annual discharge regime in the high mountain basin of Belá River in Podbanské, Acta Hydrologica Slovaca, 10, 300-311, 2009.

Pekárová, P., Halmová, D., Bačová Mitková, V., Miklánek, P., Pekár, J., and Škoda, P.: Historical flood marks and flood frequency analysis of the Danube River at Bratislava, Slovakia, J. Hydrol. Hydromech., 61, 326-333, doi:10.2478/johh-20130041, 2013.

Petrow, T. and Merz, B.: Trends in flood magnitude, frequency and seasonality in Germany in the period 1951-2002, J. Hydrol., 371, 129-141, doi:10.1016/j.jhydrol.2009.03.024, 2009.

Piégay, H., Walling, D. E., Landon, N., He, Q., Liébault, F., and Petiot, R.: Contemporary changes in sediment yield in an alpine mountain basin due to afforestation (the upper Drôme in France), Catena, 55, 183-212, doi:10.1016/S03418162(03)00118-8, 2004.

Pielke, R. A. Jr., Gratz, J., Landsea, C. W., Collins, D., Saunders, M. A., and Musulin, R.: Normalized Hurricane Damage in the United States: 1900-2005, Nat. Hazards Rev., 31, 29-42, doi:10.1061/(ASCE)1527-6988(2008)9:1(29), 2008.

Pinskwar, I., Kundzewicz, Z. W., Peduzzi, P., Brakenbridge, G. R., Stahl, K., and Hannaford, J.: Changing Floods in Europe, in: Changes in Flood Risk in Europe, edited by: Kundzewicz, Z. W., IAHS Press, Wallingford, UK, 83-96, 2012.

Pires, C., Vautard, R., and Talagrand, O.: On extending the limits of variational assimilation in nonlinear chaotic systems, Tellus A, 48, 96-121, doi:10.1034/j.1600-0870.1996.00006.x, 1996.

Pires, C. A. L. and Perdigão, R. A. P.: Non-Gaussianity and asymmetry of the winter monthly precipitation estimation from the NAO, Mon. Weather Rev., 135, 430-448, doi:10.1175/MWR3407.1, 2007.

Pires, C. A. L. and Perdigão, R. A. P.: Minimum mutual information and non-Gaussianity through the maximum entropy method: theory and properties, Entropy, 14, 1103-1126, doi:10.3390/e14061103, 2012.

Pires, C. A. L. and Perdigão, R. A. P.: Minimum mutual information and non-Gaussianity through the maximum entropy method: estimation from finite samples, Entropy, 15, 721-752, doi:10.3390/e15030721, 2013.

Prosdocimi, I., Kjeldsen, T. R., and Svensson, C.: Non-stationarity in annual and seasonal series of peak flow and precipitation in the UK, Nat. Hazards Earth Syst. Sci., 14, 1125-1144, doi:10.5194/nhess-14-1125-2014, 2014.

Prudhomme, C., Wilby, R., Crooks, S., Kay, A., and Reynard, N.: Scenario-neutral approach to climate change impact studies: application to flood risk, J. Hydrol., 390, 198-209, doi:10.1016/j.jhydrol.2010.06.043, 2010.

Quevauviller, P.: Adapting to climate change: reducing water-related risks in Europe - EU policy and re- search considerations, Environ. Sci. Policy, 14, 722-729, doi:10.1016/j.envsci.2011.02.008, 2011.

Quevauviller, P., Barceló, D., Beniston, M., Djordjevic, S., Harding, R. J., Iglesias, A., Ludwig, R., Navarra, A., Navarro Ortega, A., Mark, O., Roson, R., Sempere, D., Stoffel, M., van Lanen, H. A. J., and Werner, M.: Integration of research advances in modelling and monitoring in support of WFD river basin management planning in the context of climate change, Sci. Total Environ., 440, 167-177, doi:10.1016/j.scitotenv.2012.07.055, 2012.

Raff, D. A., Pruitt, T., and Brekke, L. D.: A framework for assessing flood frequency based on climate projection information, Hydrol. Earth Syst. Sci., 13, 2119-2136, doi:10.5194/hess-13-21192009, 2009.

Rajczak, J., Pall, P., and Schär, C.: Projections of extreme precipitation events in regional climate simulations for Europe and the Alpine region, J. Geophys. Res., 118, 3610-3626, doi:10.1002/jgrd.50297, 2013.

Ranzi, R., Bochicchio, M., and Bacchi, B.: Effects on floods of recent afforestation and urbanisation in the Mella River (Italian Alps), Hydrol. Earth Syst. Sci., 6, 239-254, doi:10.5194/hess6-239-2002, 2002.

Rawlins, F., Ballard, S. P., Bovis, K. J., Clayton, A. M., Li, D., Inverarity, G. W., Lorenc, A. C., and Payne, T. J.: The Met Office global four-dimensional variational data assimilation scheme, Q. J. Roy. Meteor. Soc., 133, 347-362, doi:10.1002/qj.32, 2007.

Reihan, A., Koltsova, T., Kriaučiūnienè, J., Lizuma, L., and Meilutytė-Barauskienè, D.: Changes in water discharges of the Baltic states rivers in the 20th century and its relation to climate change, Nord. Hydrol., 38, 401-412, doi:10.2166/nh.2007.020, 2007.

Reihan, A., Kriaučiūnienė, J., Kolcova, T., and Saul, M.: Temporal variation of spring flood in rivers of the Baltic States, Hydrol. Res., 43, 301-314, doi:10.2166/nh.2012.141, 2012.

Renard, B. and Lang, M.: Use of a Gaussian copula for multivariate extreme value analysis: some case studies in hydrology, Adv. Water Resour., 30, 897-912, doi:10.1016/j.advwatres.2006.08.001, 2007.

Renard, B., Lang, M., Bois, P., Dupeyrat, A., Mestre, O., Niel, H., Sauquet, E., Prudhomme, C., Parey, S., Paquet, E., Neppel, L., and Gailhard, J.: Regional methods for trend detection: assessing field significance and regional consistency, Water Resour. Res., 44, W08419, doi:10.1029/2007WR006268, 2008.

Roald, L. A.: The large flood of 1860 in Norway, in: The Extremes of the Extreme: Extraordinary Floods, Publ. No. 271, edited by: Snorrason, A., Finnsdottir, H. P., and Moss, M. E., IAHS Press, UK, 173-179, 2002.

Roald, L. A.: Two major 18th century flood disasters in Norway, in: Palaeofloods, Historical Data and Climatic Variability: Applications in Flood Risk Assessment, edited by: Thorndycraft, V. R., Benito, G., Barriendos, M., and Llasat, M. C., Centro de Ciencias Medioambientales, Madrid, Spain, 131-136, 2003.

Robinson, M.: 30 years of forest hydrology changes at Coalburn: water balance and extreme flows, Hydrol. Earth Syst. Sci., 2, 233-238, doi:10.5194/hess-2-233-1998, 1998.

Robinson, M., Cognard-Plancq, A. L., Cosandey, C., David, J., Durand, P., Führer, H. W., Hall, R., Hendriques, M., Marc, V., McCarthy, R. R., McDonnell, M., Martin, C., Nisbet, T., O'Dea, P., Rodgers, M., and Zoller, A.: Studies of the impact of forests on peak flows and baseflows: a European perspective, Forest 
Ecol. Manage., 186, 85-97, doi:10.1016/S0378-1127(03)00238X, 2003.

Robson, A. J., Jones, T. K., Reed, D. W., and Bayliss, A. C.: A study of national trend and variation in UK floods, Int. J. Climatol., 18, 165-182, doi:10.1002/(SICI)10970088(199802)18:2<165::AID-JOC230>3.0.CO;2-\#, 1998.

Rohr, C.: Extreme Naturereignisse im Ostalpenraum, Naturerfahrung im Spätmittelalter und am Beginn der Neuzeit, Böhlau Verlag, Köln, Weimar, Wien, 640 pp., 2007.

Rojas, R., Feyen, L., Dosio, A., and Bavera, D.: Improving panEuropean hydrological simulation of extreme events through statistical bias correction of RCM-driven climate simulations, Hydrol. Earth Syst. Sci., 15, 2599-2620, doi:10.5194/hess-15-25992011, 2011.

Rojas, R., Feyen, L., Bianchi, A., and Dosio, A.: Assessment of future flood hazard in Europe using a large ensemble of biascorrected regional climate simulations, J. Geophys. Res.-Atmos., 117, D17109, doi:10.1029/2012JD017461, 2012.

Rokoengen, K., Norman Jespersen, M., Kleiv, R. A., and Saeterbøe, E.: The 1345 slide and flood disaster in the Gauldalen valley, Mid-Norway: a new interpretation, Norsk Geogr. Tidsskr., 55, 57-70, doi:10.1080/00291950121138, 2001.

Runyan, C. W., D'Odorico, P., and Lawrence, D.: Physical and biological feedbacks of deforestation, Rev. Geophys., 50, RG4006, doi:10.1029/2012RG000394, 2012.

Sadri, S., Madsen, H., Mikkelsen, P. S., and Burn, D. H.: Analysis of extreme rainfall trends in Denmark, 33rd IAHR Congress: Water Engineering for a Sustainable Environment, IAHR, Vancouver, Canada, 1731-1738, 2009.

Salazar, S., Francés, F., Komma, J., Blume, T., Francke, T., Bronstert, A., and Blöschl, G.: A comparative analysis of the effectiveness of flood management measures based on the concept of "retaining water in the landscape" in different European hydroclimatic regions, Nat. Hazards Earth Syst. Sci., 12, 3287-3306, doi:10.5194/nhess-12-3287-2012, 2012.

Salinas, J. L., Castellarin, A., Kohnová, S., and Kjeldsen, T. R.: On the quest for a pan-European flood frequency distribution: effect of scale and climate, Hydrol. Earth Syst. Sci. Discuss., 10, 63216358, doi:10.5194/hessd-10-6321-2013, 2013.

Samaniego, L., Kumar, R., and Jackisch, C.: Predictions in a datasparse region using a regionalized grid-based hydrologic model driven by remotely sensed data, Hydrol. Res., 42, 338-355, doi:10.2166/nh.2011.156, 2011.

Sang, Y.-F., Wang, Z., and Liu, C.: Period identification in hydrologic time series using empirical mode decomposition and maximum entropy spectral analysis, J. Hydrol., 424, 154-164, doi:10.1016/j.jhydrol.2011.12.044, 2012.

Santos, F. D., Forbes, K., and Moita, R.: Climate Change in Portugal, Scenarios, Impacts and Adaptation Measures, SIAM Project, Gradiva, Lisbon, Portugal, 2002.

Schmidli, J., Frei, C., and Vidale, P. L.: Downscaling from GCM precipitation: a benchmark for dynamical and statistical downscaling methods, Int. J. Climatol., 26, 679-689, doi:10.1002/joc.1287, 2006.

Schmocker-Fackel, P. and Naef, F.: More frequent flooding?, Changes in flood frequency in Switzerland since 1850, J. Hydrol., 381, 1-8, doi:10.1016/j.jhydrol.2009.09.022, 2010a.
Schmocker-Fackel, P. and Naef, F.: Changes in flood frequencies in Switzerland since 1500, Hydrol. Earth Syst. Sci., 14, 1581-1594, doi:10.5194/hess-14-1581-2010, 2010b.

Seneviratne, S. I., Nicholls, N., Easterling, D., Goodess, C. M., Kanae, S., Kossin, J., Luo, Y., Marengo, J., McInnes, K., Rahimi, M., Reichstein, M., Sorteberg, A., Vera, C., and Zhang, X.: Changes in climate extremes and their impacts on the natural physical environment, in: Managing the Risks of Extreme Events and Disasters to Advance Climate Change Adaptation, A Special Report of Working Groups I and II of the Intergovernmental Panel on Climate Change (IPCC), edited by: Field, C. B., Barros, V., Stocker, T. F., Qin, D., Dokken, D. J., Ebi, K. L., Mastrandrea, M. D., Mach, K. J., Plattner, G.-K., Allen, S. K., Tignor, M., and Midgley, P. M., Cambridge University Press, Cambridge, UK, and New York, USA, 109-230, 2012.

Sheffer, N. A., Enzel, Y., Benito, G., Grodek, T., Poart, N., Lang, M., Naulet, R., and Cœur, D.: Paleofloods and historical floods of the Ardèche river, France, Water Resour. Res., 39, 1376, doi:10.1029/2003WR002468, 2003.

Sheffer, N. A., Rico, M., Enzel, Y., Benito, G., and Grodek, T.: The palaeoflood record of the Gardon river, France: a comparison with the extreme 2002 flood event, Geomorphology, 98, 71-83, doi:10.1016/j.geomorph.2007.02.034, 2008.

Sivapalan, M., Savenije, H. H., and Blöschl, G.: Socio-hydrology: a new science of people and water, Hydrol. Process., 26, 12701276, doi:10.1002/hyp.8426, 2012.

Solín, L'.: Analysis of floods occurrence in Slovakia in the period 1996-2006, J. Hydrol. Hydromech., 56, 95-115, 2008.

Solín, L'., Feranec, J., and Nováček, J.: Land cover changes in small catchments in Slovakia during 1990-2006 and their effects on frequency of flood events, Nat. Hazards, 56, 195-214, doi:10.1007/s11069-010-9562-1, 2011.

Somlyódy, L., Nováky, B., and Simonffy, Z.: Éghajlatváltozás, szélsőségek és vízgazdálkodás, KLÍMA-21 FÜZETEK - Climate change, extremes and water management "CLIMA-21" Brochures Climate change - impact - responses, 61, 15-32, 2010.

Stahl, K., Hisdal, H., Hannaford, J., Tallaksen, L. M., van Lanen, H. A. J., Sauquet, E., Demuth, S., Fendekova, M., and Jódar, J.: Streamflow trends in Europe: evidence from a dataset of nearnatural catchments, Hydrol. Earth Syst. Sci., 14, 2367-2382, doi:10.5194/hess-14-2367-2010, 2010.

Stahl, K., Tallaksen, L. M., Hannaford, J., and van Lanen, H. A. J.: Filling the white space on maps of European runoff trends: estimates from a multi-model ensemble, Hydrol. Earth Syst. Sci., 16, 2035-2047, doi:10.5194/hess-16-2035-2012, 2012.

Stainforth, D. A., Allen, M. R., Tredger, E., and Smith, L. A.: Confidence, uncertainty and decision-support relevance in climate predictions, Philos. T. Roy. Soc. A, 365, 2145-2161, doi:10.1098/rsta.2007.2074, 2007.

Stedinger, J. R. and Cohn, T. A.: Flood frequency analysis with historical and Paleoflood information, Water Resour. Res., 22, 785793, doi:10.1029/WR022i005p00785, 1986.

Steele-Dunne, S., Lynch, P., McGrath, R., Semmler, T., Wang, S., Hanafin, J., and Nolan, P.: The impacts of climate change on hydrology in Ireland, J. Hydrol., 356, 28-45, 2008.

Stephan, U. and Gutknecht, D.: Hydraulic resistance of submerged flexible vegetation, J. Hydrol., 269, 27-43, doi:10.1016/S00221694(02)00192-0, 2002. 
Strupczewski, W., Singh, V., and Mitosek, H.: Non-stationary approach to at-site flood frequency modelling, III. Flood analysis of Polish rivers, J. Hydrol., 248, 152-167, doi:10.1016/S00221694(01)00399-7, 2001.

Syvitski, J. P. M.: Supply and flux of sediment along hydrological pathways: research for the 21st Century, Global Planet. Change, 39, 1-11, doi:10.1016/S0921-8181(03)00008-0, 2003.

Syvitski, J. P. M., Vörösmarty, C. J., Kettner, A. J., and Breen, P.: Impact of humans on the flux of terrestrial sediment to the global coastal ocean, Science, 308, 376-380, doi:10.1126/science.1109454, 2005.

Szolgay, J., Danáčová, M., Jurčák, S., and Spál, P.: Multilinear flood routing using empirical wave-speed discharge relationships: case study on the Morava River, J. Hydrol. Hydromech., 56, 213-227, 2008.

Szolgayová, E., Laaha, G., Blöschl, G., and Bucher, C.: Factors influencing long range dependence in streamflow of European rivers, Hydrol. Process., 28, 1573-1586, doi:10.1002/hyp.9694, 2013.

Taleb, N. N.: The Black Swan: The Impact of the Highly Improbable, Random House, New York, 2007.

Ter Braak, C. J. F. and Prentice, I. C.: A theory of gradient analysis, Adv. Ecol. Res., 18, 271-317, doi:10.1016/S00652504(03)34003-6, 1988.

Teutschbein, C. and Seibert, J.: Bias correction of regional climate model simulations for hydrological climate-change impact studies: review and evaluation of different methods, J. Hydrol., 456, 12-29, doi:10.1016/j.jhydrol.2012.05.052, 2012.

Teutschbein, C. and Seibert, J.: Is bias correction of regional climate model (RCM) simulations possible for nonstationary conditions?, Hydrol. Earth Syst. Sci., 17, 5061-5077, doi:10.5194/hess-17-5061-2013, 2013.

Thodsen, H.: The influence of climate change on stream flow in Danish rivers, J. Hydrol., 333, 226-238, doi:10.1016/j.jhydrol.2006.08.012, 2007.

Turco, M., Sanna, A., Herrera, S., Llasat, M. C., and Gutierrez, J. M.: Large biases and inconsistent climate change signals in ENSEMBLES regional projections, Climatic Change, 120, 859869, doi:10.1007/s10584-013-0844-y, 2013.

Ulbrich, U., Brücher, T., Fink, A. H., Leckebusch, G. C., Krüger, A., and Pinto, J. G.: The central European floods of August 2002: Part 1 - Rainfall periods and flood development, Weather, 58, 371-377, doi:10.1256/wea.61.03A, 2003.

Valentová, J., Valenta, P., and Weyskrabová, L.: Assessing the retention capacity of a floodplain using a $2 \mathrm{~d}$ numerical model, J. Hydrol. Hydromech., 58, 221-232, doi:10.2478/v10098-010-0021$1,2010$.

van der Ent, R. J. and Savenije, H. H. G.: Length and time scales of atmospheric moisture recycling, Atmos. Chem. Phys., 11, 18531863, doi:10.5194/acp-11-1853-2011, 2011.

Van Der Heijden, K.: Scenarios: The Art of Strategic Conversation, Wiley and Sons, Chichester, England, 321 pp., 1996.

Van der Linden, P. and Mitchell, J. F. B. (Eds.): Climate Change and its Impacts: Summary of Research and Results From the ENSEMBLES Project, Met Office Hadley Centre, Exeter, UK, 160 pp., 2009.

Van Pelt, S. C. and Swart, R. J.: Climate change risk management in transnational river basins: the Rhine, Water Resour. Manage., 25, 3837-3861, doi:10.1007/s11269-011-9891-1, 2011.
Veijalainen, N., Lotsari, E., Alho, P., Vehviläinen, B., and Käyhkö, J.: National scale assessment of climate change impacts on flooding in Finland, J. Hydrol., 391, 333-350, doi:10.1016/j.jhydrol.2010.07.035, 2010.

Ventura, V., Paciorek, C. J., and Risbey, J. S.: Controlling the proportion of falsely rejected hypotheses when conducting multiple tests with climatological data, J. Climate, 17, 4343-4356, doi:10.1175/3199.1, 2004.

Vetter, M., Höfle, B., Hollaus, M., Gschöpf, C., Mandlburger, G., Pfeifer, N., and Wagner, W.: Vertical vegetation structure analysis and hydraulic roughness determination using dense ALS point cloud data - a voxel based approach, in: International Archives of Photogrammetry, Remote Sensing and Spatial Information Sciences, Vol. XXXVIII, 5/W12, Proceedings of the ISPRS Workshop Laser Scanning, 29-31 August 2011, Calgary, Canada, 1-6, 2011.

Viglione, A., Chirico, G. B., Komma, J., Woods, R., Borga, M., and Blöschl, G.: Quantifying space-time dynamics of flood event types, J. Hydrol., 394, 213-229, doi:10.1016/j.jhydrol.2010.05.041, 2010a.

Viglione, A., Borga, M., Balabanis, P., and Blöschl, G.: Barriers to the exchange of hydrometeorological data in Europe: results from a survey and implications for data policy, J. Hydrol., 394, 63-77, doi:10.1016/j.jhydrol.2010.03.023, 2010b.

Viglione, A., Merz, R., Salinas, J. S., and Blöschl, G.: Flood frequency hydrology: 3. A Bayesian analysis, Water Resour. Res., 49, 675-692, doi:10.1029/2011WR010782, 2013.

Viglione, A., Di Baldassarre, G., Brandimarte, L., Kuil, L., Carr, G., Salinas, J. L., Scolobig, A., and Blöschl, G.: Insights from socio-hydrology modelling on dealing with flood risk - roles of collective memory, risk-taking attitude and trust, J. Hydrol., doi:10.1016/j.jhydrol.2014.01.018, in press, 2014.

Viner, D.: A qualitative assessment of the sources of uncertainty in climate change impacts assessment studies, in: Climatic Change: Implications for the Hydrological Cycle and for Water Management, edited by: Beniston, M., Adv. Global Change Res., 10, 139-149, doi:10.1007/0-306-47983-4_8, 2003.

Vorogushyn, S. and Merz, B.: Flood trends along the Rhine: the role of river training, Hydrol. Earth Syst. Sci., 17, 3871-3884, doi:10.5194/hess-17-3871-2013, 2013.

Vörösmarty, C. J., Meybeck, M., Fekete, B., Sharmad, K., Green, P., and Syvitski, J. P. M.: Anthropogenic sediment retention: major global impact from registered river impoundments, Global Planet. Change, 39, 169-190, doi:10.1016/S09218181(03)00023-7, 2003.

Wagener, T. M., Sivapalan, M., Troch, P. A., McGlynn, B. L., Harman, C. J., Gupta, H. V., Kumar, P., Rao, P. S. C., Basu, N. B., and Wilson, J. S.: The future of hydrology: an evolving science for a changing world, Water Resour. Res., 46, W05301, doi:10.1029/2009WR008906, 2010.

Walker, G. T. and Bliss, E. W.: World weather, V. Mem. R. Meteorol. Soc., 4, 53-84, 1932.

Werritty, A., Paine, J., Macdonald, N., Rowan, J., and McEwen, L.: Use of multi-proxy flood records to improve estimates of flood risk: lower River Tay, Scotland, Catena, 66, 107-119, doi:10.1016/j.catena.2005.07.012, 2006.

Wetter, O., Pfister, C., Weingartner, R., Luterbacher, J., Reist, T., and Trösch, J.: The largest floods in the High Rhine basin since 1268 assessed from documentary and 
instrumental evidence, Hydrolog. Sci. J., 56, 733-758, doi:10.1080/02626667.2011.583613, 2011.

Wheater, H. and Evans, E.: Land use, water management and future flood risk, Land Use Policy, 26, S251-S264, doi:10.1016/j.landusepol.2009.08.019, 2009.

White, G. F.: Human Adjustment to Floods, Department of Geography Research Paper No. 29, University of Chicago, Chicago, 1945.

Whitfield, P. H., Burn, D. H., Hannaford, J., Higgins, H., Hodgkins, G. A., Marsh, T., and Looser, U.: Reference hydrologic networks, I. The status and potential future directions of national reference hydrologic networks for detecting trends, Hydrolog. Sci. J., 57, 1568-1579, doi:10.1080/02626667.2012.728706, 2012.

Wilby, R. L.: When and where might climate change be detectable in UK river flows?, Geophys. Res. Lett., 33, L19407, doi:10.1029/2006GL027552, 2006.

Wilby, R. L. and Dessai, S.: Robust adaptation to climate change, Weather, 65, 180-185, doi:10.1002/wea.543, 2010.

Wilby, R. L. and Quinn, N. W.: Reconstructing multi-decadal variations in fluvial flood risk using atmospheric circulation patterns, J. Hydrol., 487, 109-121, doi:10.1016/j.jhydrol.2013.02.038, 2013.

Wilby, R. L., Wigley, T., Conway, D., Jones, P., Hewitson, B., Main, J., and Wilks, D.: Statistical downscaling of general circulation model output: a comparison of methods, Water Resour. Res., 34, 2995-3008, doi:10.1029/98WR02577, 1998.

Wilkinson, M. E., Quinn, P. F., and Welton, P.: Runoff management during the September 2008 floods in the Belford catchment, Northumberland, J. Flood Risk Manage., 3, 285-295, doi:10.1111/j.1753-318X.2010.01078.x, 2010.

Willems, P.: Adjustment of extreme rainfall statistics accounting for multidecadal climate oscillations, J. Hydrol., 490, 126-133, doi:10.1016/j.jhydrol.2013.03.034, 2013.

Wilson, D., Hisdal, H., and Lawrence, D.: Has streamflow changed in the Nordic countries?, Recent trends and comparisons to hydrological projections, J. Hydrol., 394, 334-346, doi:10.1016/j.jhydrol.2010.09.010, 2010.
Wood, A. W., Leung, L. R., Sridhar, V., and Lettenmaier, D. P.: Hydrologic implications of dynamical and statistical approaches to downscaling climate model outputs, Climatic Change, 64, 189216, doi:10.1023/B:CLIM.0000013685.99609.9e, 2004.

Wösten, J. H. M., Pachepsky, Y. A., and Rawls, W. J.: Pedotransfer functions: bridging the gap between available basic soil data and missing soil hydraulic characteristics, J. Hydrol., 251, 123-150, doi:10.1016/S0022-1694(01)00464-4, 2001.

Yang, W., Andréasson, J., Graham, L. P., Olsson, J., Rosberg, J., and Wetterhall, F.: Distribution based scaling to improve usability of regional climate model projections for hydrological climate change impacts studies, Hydrol. Res., 41, 211-229, doi:10.2166/nh.2010.004, 2010.

Yiou, P., Ribereau, P., Naveau, P., Nogaj, M., and Brázdil, R.: Statistical analysis of floods in Bohemia (Czech Republic) since 1825, Hydrolog. Sci. J., 51, 930-945, doi:10.1623/hysj.51.5.930, 2006.

Yue, S. and Wang, C. Y.: Regional streamflow trend detection with consideration of both temporal and spatial correlation, Int. J. Climatol., 22, 933-946, doi:10.1002/joc.781, 2002.

Yue, S., Pilon, P., Phinney, B., and Cavadias, G.: The influence of autocorrelation on the ability to detect trend in hydrological series, Hydrol. Process., 16, 1807-1829, doi:10.1002/hyp.1095, 2002.

Yue, S., Kundzewicz, Z. W., and Wang, L.: Detection of changes, in: Changes in Flood Risk in Europe, edited by: Kundzewicz, Z. W., IAHS Press, Wallingford, UK, 387-434, 2012.

Zokagoa, J. M. and Soulaïmani, A.: Modeling of wettingdrying transitions in free surface flows over complex topographies, Comp. Method. Appl. M., 199, 2281-2304, doi:10.1016/j.cma.2010.03.023, 2010. 